\title{
Iterative Synthesis of Alkenes by Insertion of Lithiated Epoxides into Boronic Esters
}

\author{
Kevin Bojaryn, Stefan Fritsch, Christoph Hirschhäuser* \\ Institute for Organic Chemistry University of Duisburg-Essen, 45117 Essen, Germany. Fax: (+49 201183 4259) \\ E-mail: christoph.hirschhaeuser@uni-due.de
}

Author contribution: S. Fritsch conducted experiments towards exploiting the different steric demand of alkyl substituents for the synthesis of $\mathbf{3 f}$ and $\mathbf{3 g}$. All other experiments were conducted by K. Bojaryn. C. Hirschhäuser conceived the project and wrote the manuscript.

\section{Contents}

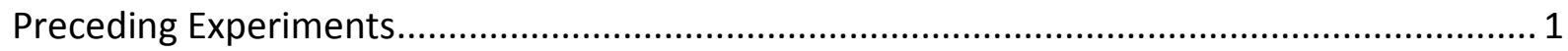

Alkene Formation from a lithiated Benzoate and an $\alpha$-Halo Boronic Ester....................................... 1

Early Attempts at the Synthesis of Alkenes from Epoxide Insertion Products ................................. 3

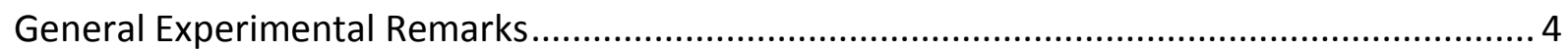

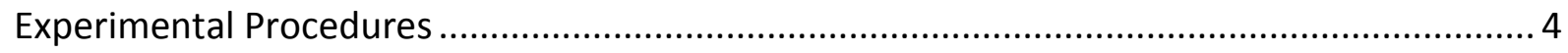

Synthesis/Sources of monosubstituted Epoxides ......................................................................... 4

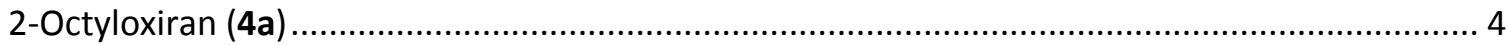

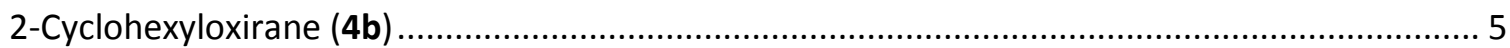

tert.-Butyldimethyl((8-(oxiran-2-yl)octyl)oxy)silan (4e) ........................................................... 5

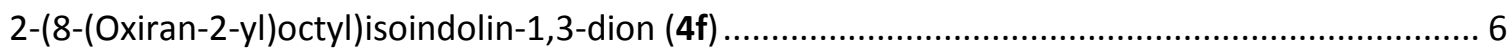

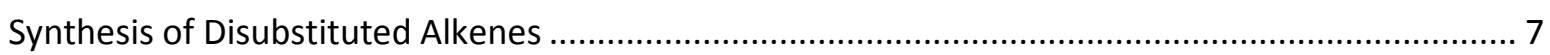

General Procedure GP1: Synthesis of Disubstituted Alkenes ................................................... 7

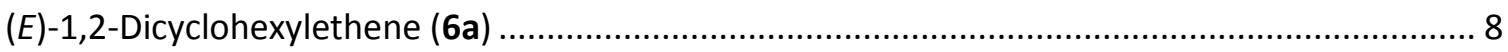

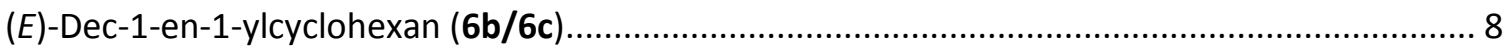

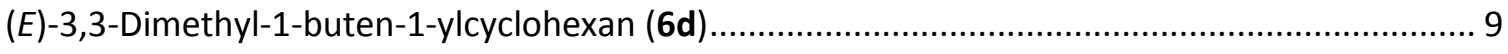

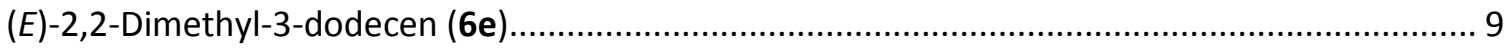

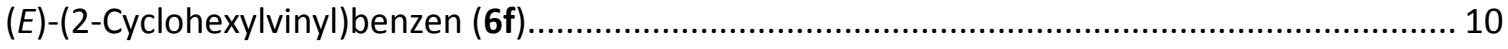

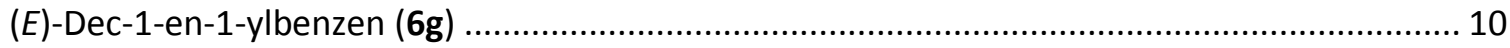

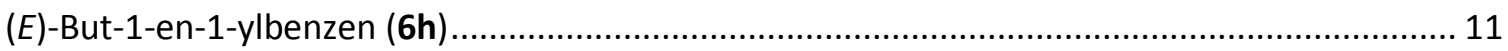

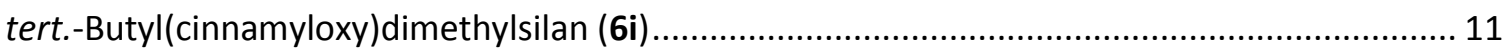

(E)-tert.-Butyldimethyl((10-phenyldec-9-en-1-yl)oxy)silan (6k) ................................................. 12

(E)-tert.-Butyl((10-cyclohexyldec-9-en-1-yl)oxy)dimethylsilan (6I) ............................................ 12

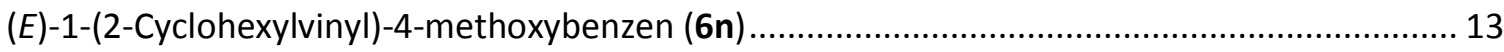

Synthesis/Sources of Disubstituted Epoxides …........................................................................... 14 
General Procedure GP2: Epoxidation of Di- and Trisubstituted Alkenes 14

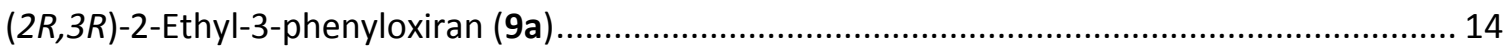

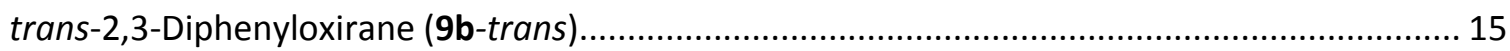

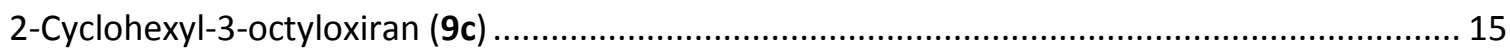

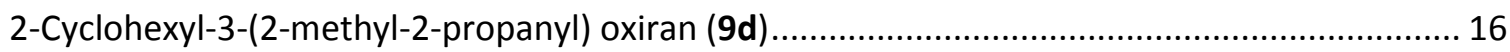

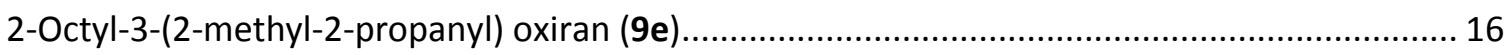

Synthesis of Trisubstituted Alkenes from trans-Epoxides ....................................................... 17

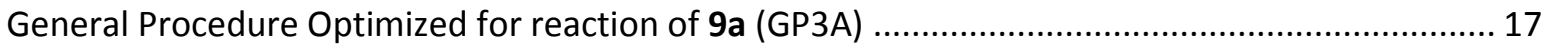

(Z)-1-Methoxy-4-(1-phenylbut-1-en-1-yl)benzen (3a) ................................................ 17

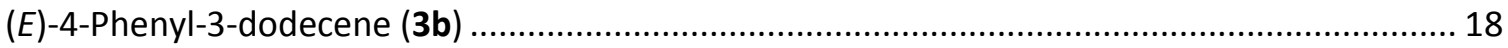

General Procedure Optimized for reaction of 9b-trans (GP3B) ........................................ 18

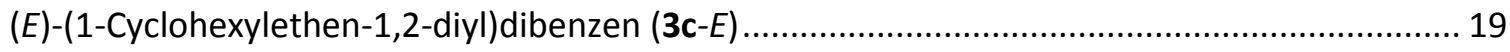

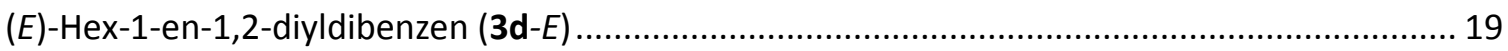

Synthesis of Trisubstituted Alkenes from cis-Stilbene Oxide - General Procedure (GP3C)............ 20

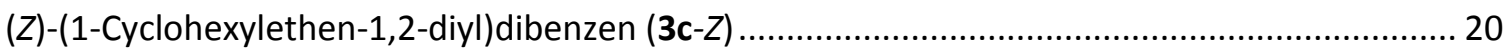

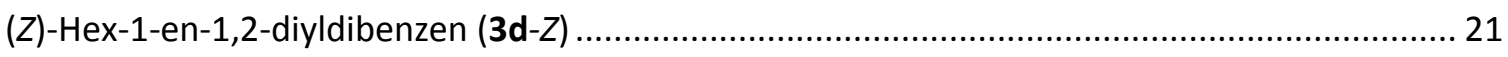

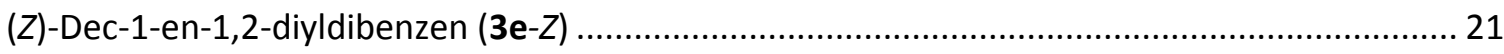

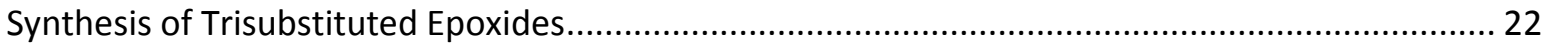

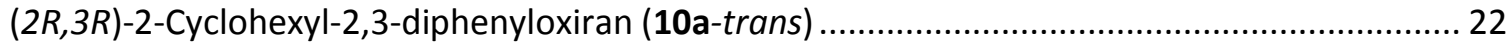

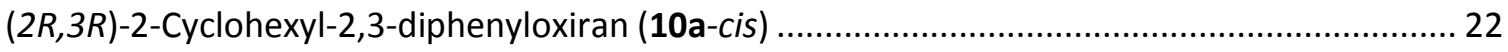

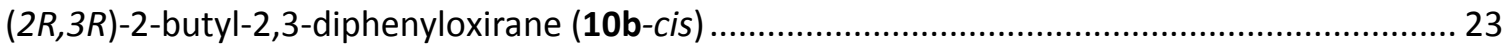

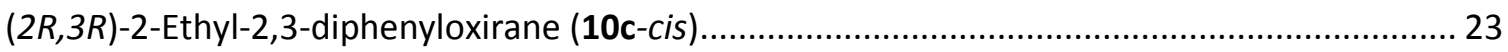

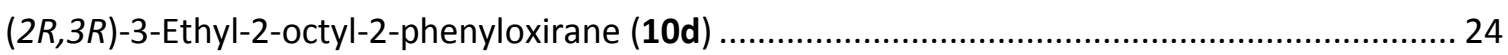

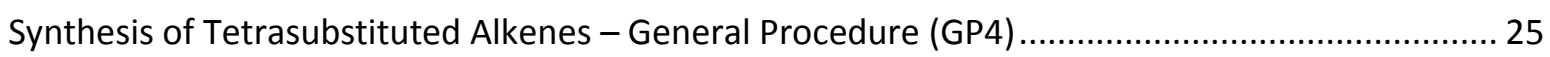

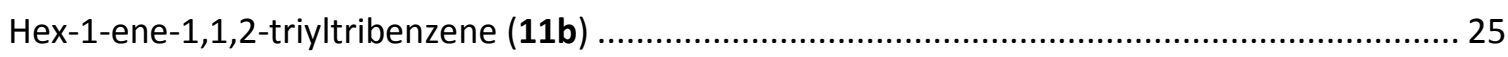

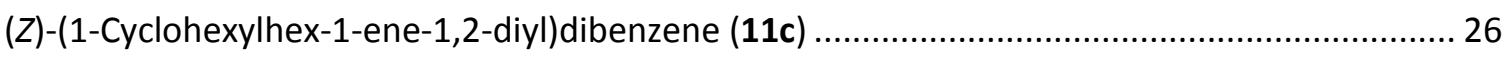

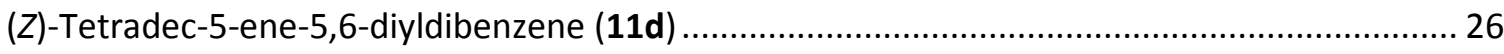

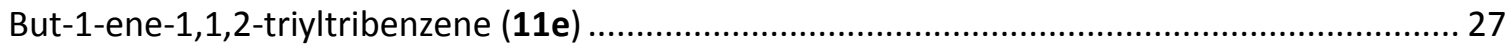

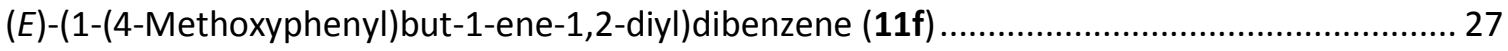

(E)-2-(4-(1,2-diphenylbut-1-en-1-yl)phenoxy)- $N, N$-dimethylethanamine $(\mathbf{1 1 g}) \ldots \ldots \ldots \ldots \ldots \ldots \ldots . . . . . . . . . .28$

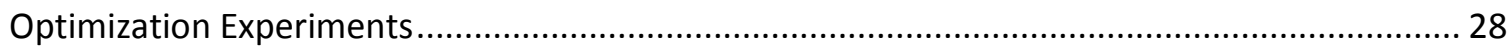

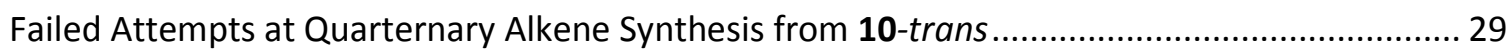

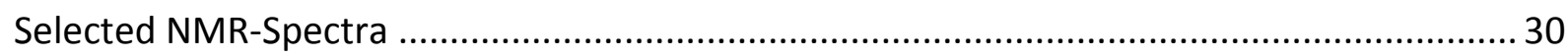




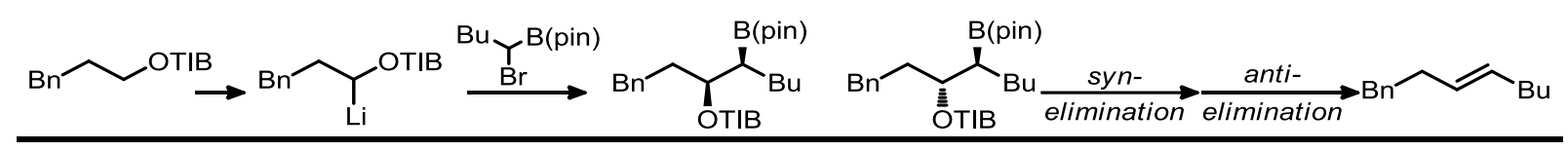

\section{Preceding Experiments}

\section{Alkene Formation from a lithiated Benzoate and an $\alpha$-Halo Boronic Ester}

In an attempt to react $\alpha$-halo boronic esters with chiral carbanions generated by direct lithiation, we found that lithiated $N, N$-diisopropylcarbamates reacted poorly with $\alpha$-haloboronic esters like S2. Although numerous different conditions were tested these reactions delivered poor yields $(<20 \%)$ and were plagued by competing alkene formation. Lithiated benzoates (Li-S1) on the other hand performed much better in this type of reaction.

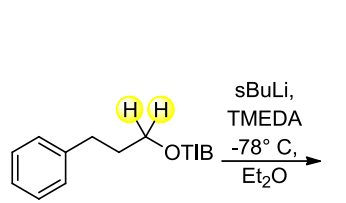

s1

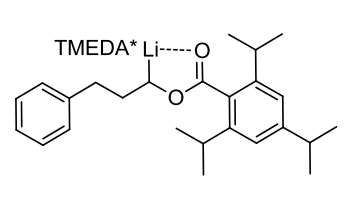

Li-S1

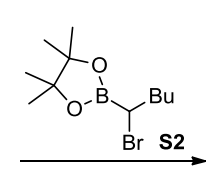

$\underset{\mathrm{Br} \mathbf{s 2}}{\longrightarrow}$

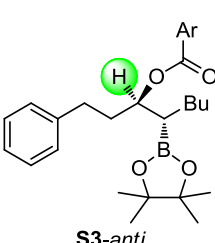

S3-anti

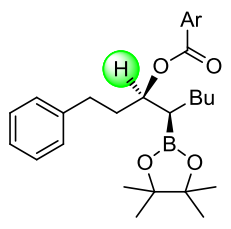

s3-syn

Benzoate S1 (1.42 equiv.) was lithiated at $-78^{\circ} \mathrm{C}$ with $s \mathrm{BuLi}$ (1.39 equiv.) and TMEDA (1.39 equiv.) in dry $\mathrm{Et}_{2} \mathrm{O}\left(3 \mathrm{~h}\right.$ ). A solution of $\mathbf{S 2}$ (1.00 equiv.) in $\mathrm{Et}_{2} \mathrm{O}$ was added at the same temperature and after $1 \mathrm{~h}$ a solution of $\mathrm{ZnCl}_{2}$ (3.9 equiv.) was added. The reaction mixture was stirred for $19 \mathrm{~h}$ during which the cooling bath was allowed to warm up to rt. After an aqueous workup $\left(\mathrm{NH}_{4} \mathrm{Cl}\right)$ a mixture of substitution products of type $\mathbf{S} 3$ was isolated. The ${ }^{1} \mathrm{H}$ NMR (A, see next page) of the crude product in $\mathrm{CDCl}_{3}$ revealed a broad multiplet 5.32-5.39 ppm (highlighted in green), which was attributed to S3-anti and S3-syn, as well as a triplet at $4.34 \mathrm{ppm}$ (highlighted in yellow), characteristic for S1. ${ }^{1}$ Based on later addition of an internal standard, yields of $18 \%$ for S1 and 65\% for S3-anti and S3-syn were calculated. A ratio of diastereomers $\mathbf{S} 3$-anti and $\mathbf{S 3}$-syn could not be determined from the data.
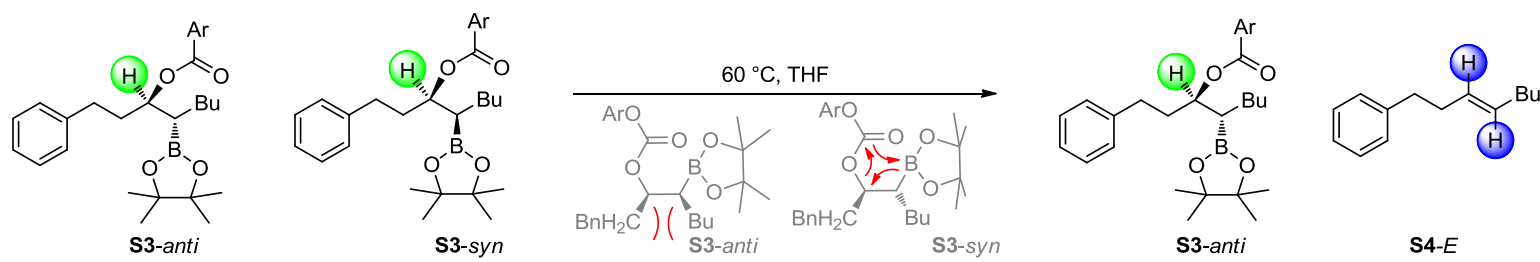

As alkene formation was a major side reaction for $\mathrm{N}, \mathrm{N}$-diisopropylcarbamates we attempted to deliberately induce thermal syn-elimination for benzoates of type $\mathbf{S 3}$ by heating. Therefore, the complete sample was dried in vacuo to remove $\mathrm{CDCl}_{3}$ before redissolving it in THF. After heating at $60{ }^{\circ} \mathrm{C}$ for $2 \mathrm{~h}$, the solvent was removed in vacuo and another ${ }^{1} \mathrm{H}$ NMR (B) was recorded in $\mathrm{CDCl}_{3}$. It revealed a doublet of triplets at $5.44 \mathrm{ppm}(\mathrm{J}=4.8,2.5 \mathrm{~Hz}$, highlighted in dark blue $){ }^{2}$ which is characteristic for the E-olefin S4-E. However, the corresponding signal for the Z-olefin S4-Z, a complex multiplet at 5.34-5.45 ppm (300 $\mathrm{MHZ} \mathrm{CDCl}_{3}$, highlighted in light blue), ${ }^{3}$ could not be assigned unambiguously as the broad multiplet assigned to $\mathbf{S} \mathbf{3}$ has a similar shift. In total the integral of signals in this area had increased by $150 \%$, relative to the triplet at $4.34 \mathrm{ppm}$ which had been

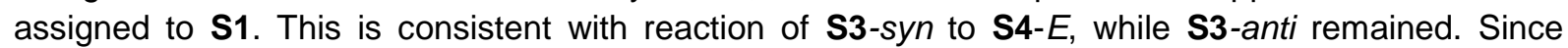
heating most likely induced a syn-elimination of $\mathbf{S 3}$, it is reasonably understandable that $\mathbf{S 3}$-anti reacts significantly slower than S3-syn. In S3-anti the alkyl substituents have to adopt a syn-periplanar orientation in order to accommodate the ecliptic conformation necessary. Based on these assumptions we attempted to convert left over S3-anti to S4-E as well using a base induced anti-elimination. Therefore, the complete sample was evaporated again to remove $\mathrm{CDCl}_{3}$.

\footnotetext{
${ }^{1}$ R. Larouche-Gauthier, T. G. Elford, V. K. Aggarwal, J. Am. Chem. Soc. 2011, 133, 16794-16797.

${ }^{2}$ X. Guo, J. Wang, C.-J. Li, Org. Lett. 2010, 12, 3176-3178. Here the relevant signal was reported as a multiplet from 5.38-5.46 ppm.

${ }^{3}$ H. Dang, N. Cox, G. Lalic, Angew. Chem. Int. Edit. 2014, 53, 752-756.
} 


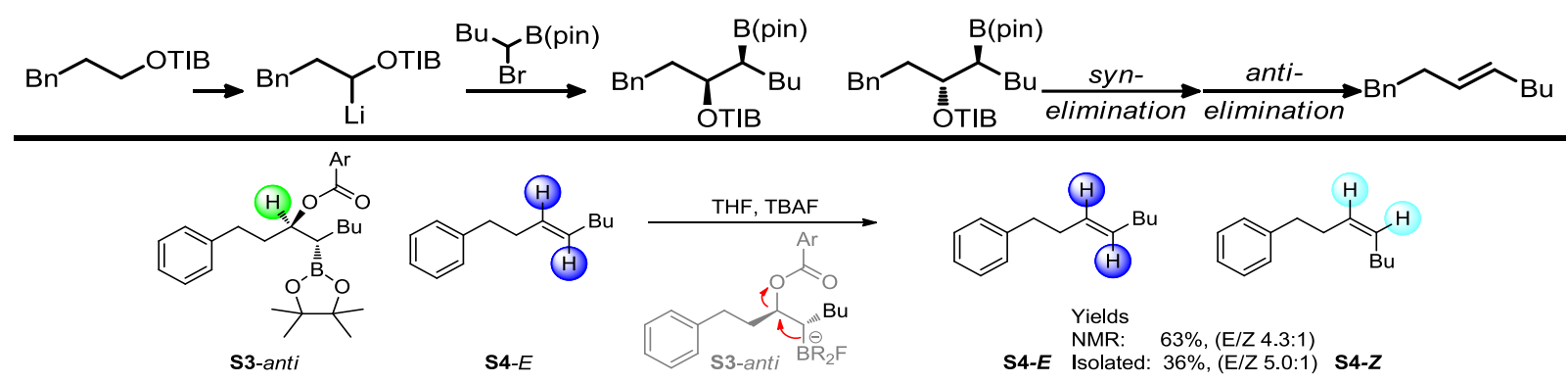

The material was dissolved in THF and TBAF (6.25 equiv.) was added. After stirring at $\mathrm{rt}$ for $17 \mathrm{~h}$ and aqueous workup (CyHex+Et $\mathrm{Et}_{2} \mathrm{O} / \mathrm{NH}_{4} \mathrm{Cl}$ ) another ${ }^{1} \mathrm{H}$ NMR (C) of the crude material revealed formation of a $4.3: 1$ mixture of $\mathbf{S 4}-E / \mathbf{S} 4-Z$ in $63 \%$ yield, judging by the internal standard. Purification by column chromatography delivered a $5: 1$ mixture of S4-E/S4-Z (36\% isolated yield). ${ }^{4}$ The reduction in yield and increase in de upon isolation, could be due to rigorous drying in vacuo (Boiling points predicted by SciFinder: S4- $E 280^{\circ} \mathrm{C}, \mathbf{S 4}-Z, 260^{\circ} \mathrm{C}$ ). We briefly attempted to apply this reaction to the synthesis of trisubstituted alkenes but turned to the epoxide based strategy described in the main article after Blakemores publication on the topic. ${ }^{5}$

A

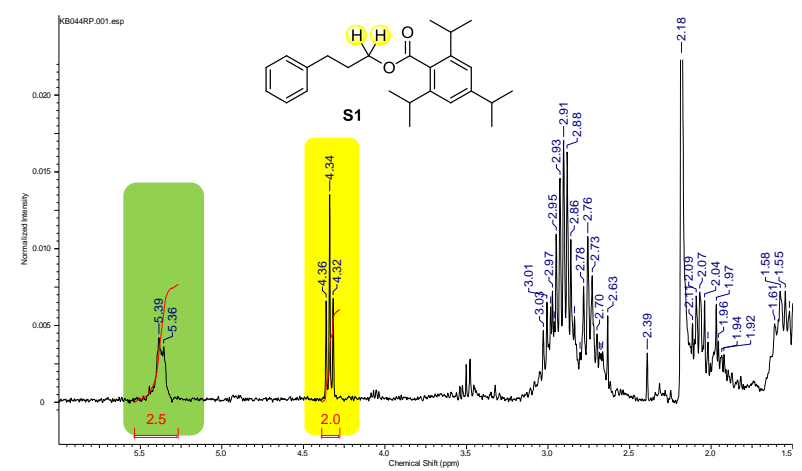<smiles>CCCC[C@H](Br)OC(C)(C)O[C@H](Br)CCCC</smiles>
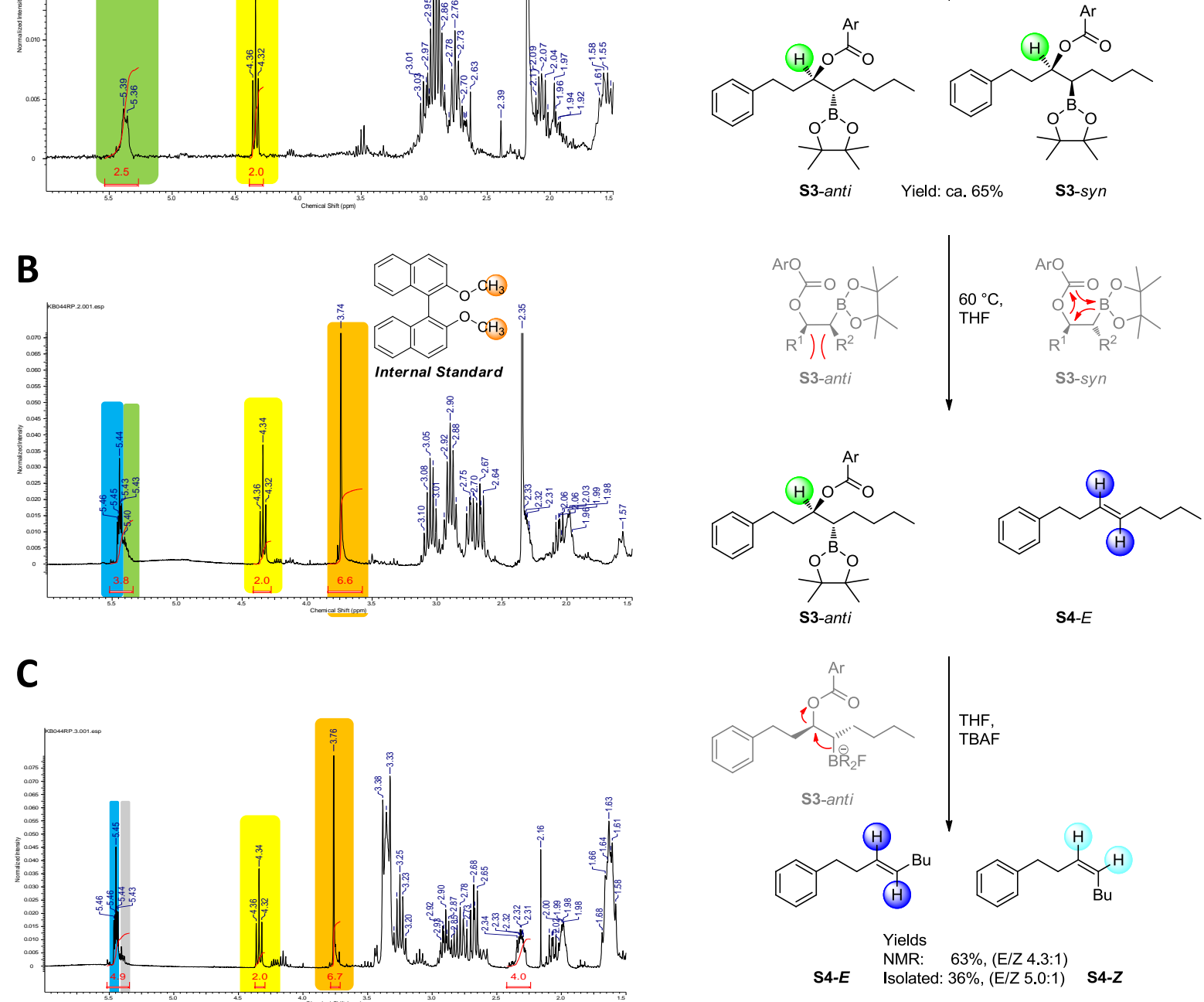

${ }^{4}{ }^{1} \mathrm{H}$ NMR S4-E (300 MHz, CHLOROFORM-d): $\delta=0.79-0.95(\mathrm{~m}, 3 \mathrm{H}), 1.20-1.36(\mathrm{~m}, 4 \mathrm{H}), 1.90-2.05(\mathrm{~m}, 2 \mathrm{H}), 2.20-2.39$ $(\mathrm{m}, 2 \mathrm{H}), 2.58-2.83(\mathrm{~m}, 2 \mathrm{H}), 5.44(\mathrm{dt}, J=4.8,2.5 \mathrm{~Hz}, 2 \mathrm{H}), 7.12-7.23(\mathrm{~m}, 3 \mathrm{H}), 7.23-7.35(\mathrm{~m}, 2 \mathrm{H}) \mathrm{ppm}$. c.f ref 2. ${ }^{1} \mathrm{H}$ NMR S4-Z $\left(300 \mathrm{MHz}, \mathrm{CDCl}_{3}\right): \delta=7.39-7.24(\mathrm{~m}, 2 \mathrm{H}), 7.24-7.11(\mathrm{~m}, 3 \mathrm{H}), 5.56-5.21(\mathrm{~m}, 2 \mathrm{H}), 2.66(\mathrm{t}, \mathrm{J}=7.7 \mathrm{~Hz}, 2 \mathrm{H}), 2.46-$ $2.23(\mathrm{~m}, 2 \mathrm{H}), 2.10-1.87(\mathrm{~m}, 2 \mathrm{H}), 1.41-1.15(\mathrm{~m}, 4 \mathrm{H}), 0.88(\mathrm{t}, \mathrm{J}=6.7 \mathrm{~Hz}, 3 \mathrm{H}) \mathrm{ppm}$. Overlaying signals reproduced from ref. 3.

5. Wu, X. Sun, K. Potter, Y. Cao, L. N. Zakharov, P. R. Blakemore, Angew. Chem. Int. Edit. 2016, 55, 12285-12289. 


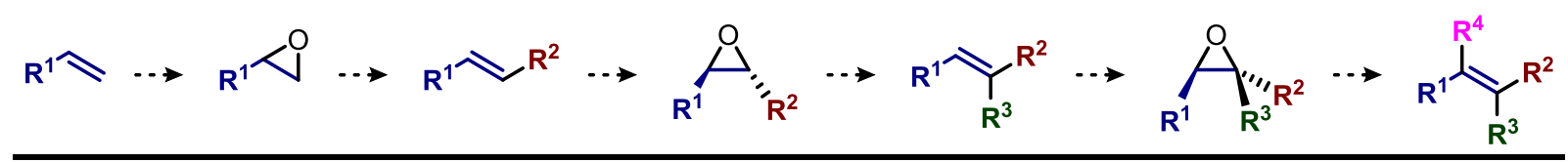

Early Attempts at the Synthesis of Alkenes from Epoxide Insertion Products

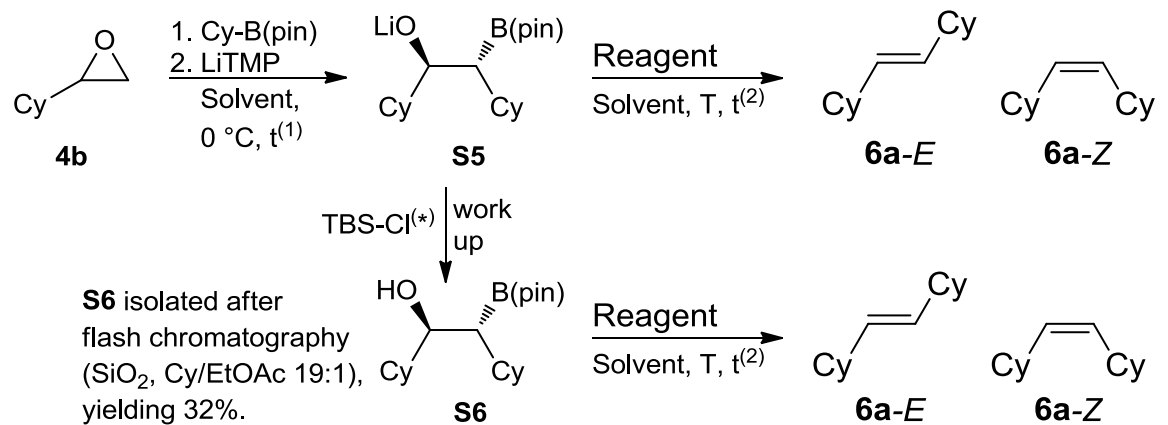

Comment: $\left(^{*}\right)$ TBS-Cl was used with the intention to isolate the corresponding silylether. This was not achieved, but the free alcohol $\mathbf{S 6}$ was obtained instead.

\begin{tabular}{|c|c|c|c|c|c|c|c|c|}
\hline Entry & $\begin{array}{l}\text { Elimination- } \\
\text { precursor }\end{array}$ & Solvent & $t^{(1)}$ & Reagent(s) & $\mathbf{T}$ & $t^{(2)}$ & $\begin{array}{c}\text { Yield } \\
\text { Alkene }\end{array}$ & E/Z-ratio \\
\hline 1 & $S 5^{(\mathrm{D})}$ & THF & o.n..$^{(B)}$ & $\mathrm{MsCl}$ & $0^{\circ} \mathrm{C}$ & $2 \mathrm{~h}$ & $47 \%$ & 16.2:1 \\
\hline 2 & $\mathbf{S} 5^{(\mathrm{D})}$ & THF & o.n. ${ }^{(B)}$ & $\mathrm{AcCl}$ & $0^{\circ} \mathrm{C}$ & $2 \mathrm{~h}$ & $26 \%^{(A)}$ & $3: 1$ \\
\hline 3 & $\mathbf{S} 5^{(\mathrm{D})}$ & THF & o.n..$^{(B)}$ & $\begin{array}{l}\text { 1. } n \mathrm{BuLi} \\
\text { 2. } \mathrm{MsCl}\end{array}$ & $-78^{\circ} \mathrm{C}$ & o.n. ${ }^{(\mathrm{B})}$ & $51 \%^{(A)}$ & $\begin{array}{l}\text { only } E- \\
\text { isomere }\end{array}$ \\
\hline 4 & $\mathbf{S} 5^{(\mathrm{D})}$ & THF & $1 \mathrm{~h}$ & $\begin{array}{l}\text { 1. } \mathrm{ZnCl}_{2} \\
\text { 2. } n \mathrm{BuLi} \\
\text { 3. } \mathrm{MsCl}\end{array}$ & $\begin{array}{l}\text { 1. } 0^{\circ} \mathrm{C} \\
\text { 2. }-78^{\circ} \mathrm{C} \\
\text { 3. }-78^{\circ} \mathrm{C}\end{array}$ & $\begin{array}{l}\text { 1. } 1 \mathrm{~h} \\
\text { 2. } 10 \mathrm{~min} \\
\text { 3. } 1 \mathrm{~h}^{\text {(C) }}\end{array}$ & $73 \%$ & $5.2: 1$ \\
\hline 5 & $S 6^{(E)}$ & THF & / & $1 \mathrm{M} \mathrm{HCl}^{(\mathrm{F})}$ & $\mathrm{rt}$ & $7 d$ & $95 \%^{(\mathrm{A})}$ & $\begin{array}{l}\text { only } E \text { - } \\
\text { isomere }\end{array}$ \\
\hline 6 & $S 6^{(\mathrm{E})}$ & $\mathrm{MeCN}$ & / & $1 \mathrm{M} \mathrm{HCl}^{(\mathrm{F})}$ & $\mathrm{rt}$ & $7 d$ & $41 \%^{(A)}$ & $\begin{array}{l}\text { only } E \text { - } \\
\text { isomere }\end{array}$ \\
\hline 7 & $S 6^{(E)}$ & THF & / & $\begin{array}{l}\text { 1. TBAF } \\
\text { 2. } 1 \mathrm{M} \mathrm{HCl}^{(\mathrm{F})}\end{array}$ & $0^{\circ} \mathrm{C}$ & $7 d$ & $34 \%$ & $0.8: 1$ \\
\hline 8 & $S 6^{(\mathrm{E})}$ & $\mathrm{MeCN}$ & / & $\begin{array}{l}\text { 1. TBAF } \\
\text { 2. } 1 \mathrm{M} \mathrm{HCl}^{(\mathrm{F})}\end{array}$ & $0^{\circ} \mathrm{C}$ & $7 d$ & $33 \%$ & $1.4: 1$ \\
\hline
\end{tabular}

(A) Yield obtained by ${ }^{1} \mathrm{H}$ NMR using dimethylbinol as an internal standard. (B) The reaction mixture was allowed to warm up to rt overnight. (C) The reaction mixture was allowed to warm up to $\mathrm{rt}$ within $1 \mathrm{~h}$. (D) $\mathbf{S} 5$ was prepared from $\mathbf{4 b}$ and reacted directly to alkene $\mathbf{6 a}$ without any isolation. (E) $\mathbf{S 6}$ was isolated before the reaction. (F) Aqueous solution. 


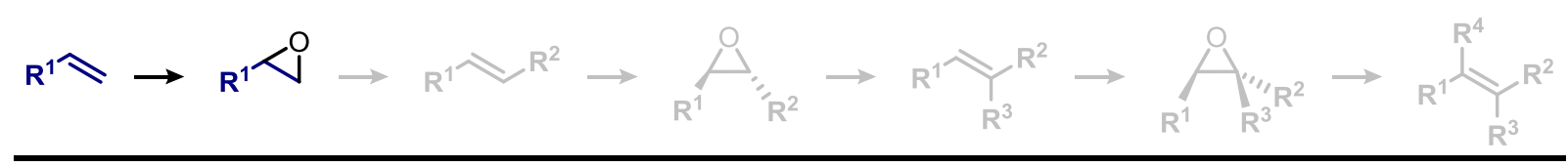

\section{General Experimental Remarks}

All reactions using dry solvents were carried out under argon in glassware dried with a heat gun under vacuum. Solvents for chromatography, unless purchased as pro analysi (p.a.) grade, were distilled over a rotary evaporator before use. THF was always freshly distilled from sodium/benzophenone, as was the case of $\mathrm{Et}_{2} \mathrm{O}$, when employed for reactions. Diisopropylamine and $N, N, N, N$-tetramethyl piperidine were distilled from $\mathrm{CaH}_{2}$ and stored in a Schlenk tube under argon. $n \mathrm{BuLi}, s B u L i, t B u L i$ and $\mathrm{ZnCl}_{2}$ were purchased as solutions and stored under argon at $+7^{\circ} \mathrm{C}$ or $\mathrm{rt}$ in the case of $n \mathrm{BuLi}$. Aged BuLi solutions were titrated against $\mathrm{N}$-benzylbenzamide. All other reagents were used as supplied from commercial sources and stored appropriately. ${ }^{1} \mathrm{H}$ - and ${ }^{13} \mathrm{C}$ NMR spectra were recorded in $\mathrm{CDCl}_{3}$ on Bruker DMX 300 and Bruker DRX 500 spectrometers. IR spectra were measured on a Jasco FT/IR-430 with ATR attachment spectrometer. Low and High resolution ESI mass spectra were recorded with a Bruker amaZon SL and a Bruker maXis $4 G$ spectrometer, respectively.

\section{Experimental Procedures}

\section{Synthesis/Sources of monosubstituted Epoxides}

$$
\text { 4a } \mathrm{R}=\mathrm{O}
$$

4a-1 R=Et<smiles>[SiH3]C1CO1</smiles>

4b<smiles>CC(C)(C)C1CO1</smiles>

4c<smiles></smiles>

4d<smiles></smiles>

$4 e$<smiles>O=C1c2ccccc2C(=O)N1CC1CO1</smiles>

2-Ethyloxirane (4a-1) and 2-(t-Butyl)oxirane (4c) were obtained commercially. $t$-Butyldimethyl-(oxiran2-ylmethoxy)-silane (4d) was prepared by silylation ${ }^{6}$ of commercially available rac-glycidol.

\section{2-Octyloxiran (4a)}

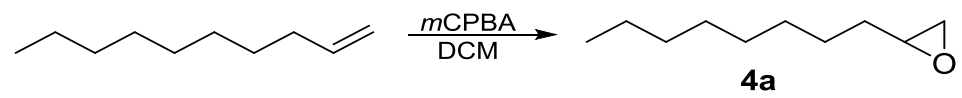

At room temperature a solution of mCPBA $(14.00 \mathrm{~g}, 81.1 \mathrm{mmol})$ in DCM $(120 \mathrm{~mL})$ was added to a solution of Dec-1-en $(5.0 \mathrm{~mL}, 48.2 \mathrm{mmol})$ in DCM $(75 \mathrm{~mL})$ in a dropwise manner through a dropping funnel. The reaction mixture was stirred overnight, after which it was quenched through the addition of a 1:1 mixture of sat. aq. $\mathrm{NaHCO}_{3} / \mathrm{Na}_{2} \mathrm{~S}_{2} \mathrm{O}_{3}$. The organic layer was extracted with brine $(200 \mathrm{~mL})$ and the aqueous layer was re-extracted with DCM $(3 \times 200 \mathrm{~mL})$. The combined organic layers were dried over $\mathrm{Na}_{2} \mathrm{SO}_{4}$ and concentrated in vacuo. After chromatography $\left(\mathrm{SiO}_{2}, \mathrm{CyHex} / \mathrm{EtOAc} 19: 1\right)$ epoxide 4a (4.15 g, $26.5 \mathrm{mmol}, 55 \%)$ was obtained as a colorless oil.

$\mathbf{R}_{f}=0.40($ CyHex/EtOAc, 19:1).

${ }^{1} \mathrm{H}$-NMR (300 MHz, CHLOROFORM- $d$ ) $\delta=2.85-2.96(\mathrm{~m}, 1 \mathrm{H}), 2.74(\mathrm{dd}, \mathrm{J}=5.00,4.06 \mathrm{~Hz}, 1 \mathrm{H}), 2.46$ (dd, J=5.16, $2.66 \mathrm{~Hz}, 1 \mathrm{H}), 1.40-1.59(\mathrm{~m}, 4 \mathrm{H}), 1.17-1.40(\mathrm{~m}, 10 \mathrm{H}), 0.81-0.94(\mathrm{~m}, 3 \mathrm{H}) \mathrm{ppm}$.

${ }^{13}$ C-NMR (75 MHz, CHLOROFORM- $d$ ) $\delta=52.6,47.3,32.7,32.0,29.7,29.6,29.4,26.1,22.8,14.2$ ppm.

${ }^{1} \mathrm{H}$ - and ${ }^{13} \mathrm{C}$ NMR data were consistent with those previously reported. ${ }^{7}$

\footnotetext{
${ }^{6}$ K. Yahata, N. Ye, K. Iso, Y. Ai, J. Lee, Y. Kishi, J. Org. Chem. 2017, 82, 8808-8830.

${ }^{7}$ Y. Monguchi, T. Marumoto, T. Ichikawa, Y. Miyake, Y. Nagae, M. Yoshida, Y. Oumi, Y. Sawama, H. Sajiki, ChemCatChem 2015, 7, 2155-2160.
} 


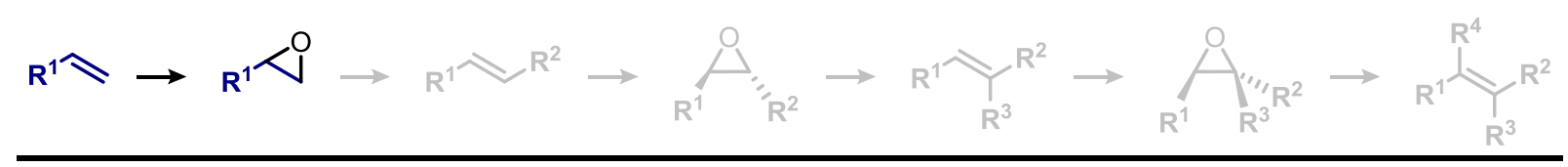

2-Cyclohexyloxirane (4b)

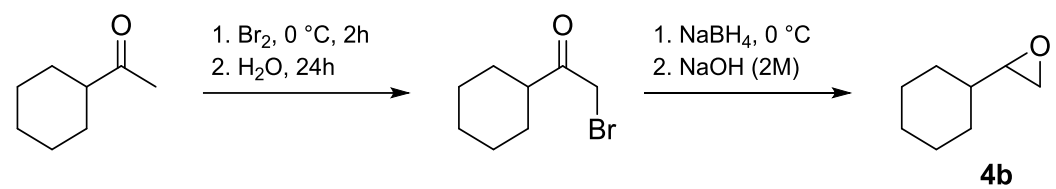

To a solution of cyclohexyl methyl ketone $(10 \mathrm{~mL}, 72.6 \mathrm{mmol})$ in $\mathrm{MeOH}(60 \mathrm{~mL})$ at $0{ }^{\circ} \mathrm{C}$ bromine $(3.8 \mathrm{~mL}, 72.6 \mathrm{mmol})$ was added via a dropping funnel over the course of $1 \mathrm{~h}$. The reaction mixture was stirred for $2 \mathrm{~h}$ at $0{ }^{\circ} \mathrm{C}$ before water $(60 \mathrm{~mL})$ was added and stirring was continued at rt overnight. The reaction mixture was diluted with $\mathrm{Et}_{2} \mathrm{O}(100 \mathrm{~mL})$ and the phases were separated. The aqueous phase was re-extracted with $\mathrm{Et}_{2} \mathrm{O}(100 \mathrm{~mL})$ and the combined organic layers were neutralized with aq. $\mathrm{K}_{2} \mathrm{CO}_{3}$ $(10 \%$, ca. $300 \mathrm{~mL})$. The organic phase was separated, dried over $\mathrm{MgSO}_{4}$ and concentrated in vacuo yielding 2-bromo-1-cyclohexylethanone $(13.03 \mathrm{~g}, 63.9 \mathrm{mmol}, 88 \%)$ as colorless oil. The crude product was dissolved in $\mathrm{MeOH}(136 \mathrm{~mL})$ and cooled to $0{ }^{\circ} \mathrm{C}$ before $\mathrm{NaBH}_{4}(3.63 \mathrm{~g}, 95.9 \mathrm{mmol})$ was added in small portions. The reaction mixture was stirred for $30 \mathrm{~min}$ at $0{ }^{\circ} \mathrm{C}$ and concentrated in vacuo. The residue was partitioned between water $(270 \mathrm{~mL})$ and $\mathrm{Et}_{2} \mathrm{O}(3 \times 70 \mathrm{~mL})$. The combined organic layers were washed with sat. aq. $\mathrm{NH}_{4} \mathrm{Cl}$ and brine, dried over $\mathrm{MgSO}_{4}$ and concentrated in vacuo. The residue was dissolved in THF $(200 \mathrm{~mL})$ and aq. $\mathrm{NaOH}(2 \mathrm{M}, 136 \mathrm{~mL})$ was added. The reaction mixture was stirred at $\mathrm{rt}$ for $2 \mathrm{~h}$, after which water $(340 \mathrm{~mL})$ was added and the suspension was extracted with $\mathrm{Et}_{2} \mathrm{O}$ $(4 \times 50 \mathrm{~mL})$. The combined organic layers were washed with brine $(100 \mathrm{~mL})$ and dried over $\mathrm{MgSO}_{4}$. The solvent was removed on a rotary evaporator ${ }^{[*]}$ and 2-cyclohexyloxirane $4 \mathbf{b}(4.40 \mathrm{~g}, 34.9 \mathrm{mmol}, 55 \%)$ was obtained as a colorless oil after distillation ${ }^{[*]}\left(7\right.$ mbar, $\left.49^{\circ} \mathrm{C}\right)$.

${ }^{1} \mathrm{H}$ NMR $\left(300 \mathrm{MHz}, \mathrm{CDCl}_{3}\right) \delta=2.56(\mathrm{dd}, \mathrm{J}=2.3,4.2 \mathrm{~Hz}, 2 \mathrm{H}), 2.42-2.29(\mathrm{~m}, 1 \mathrm{H}), 1.75(\mathrm{~m}, 1 \mathrm{H}), 1.67$ - $1.49(\mathrm{~m}, 4 \mathrm{H}), 1.27-0.90(\mathrm{~m}, 6 \mathrm{H})$.

${ }^{13} \mathrm{C}$ NMR $\left(75 \mathrm{MHz}, \mathrm{CDCl}_{3}\right) \delta=56.6,46.0,40.4,29.7,28.8,26.3,25.7,25.5$.

${ }^{1} \mathrm{H}$ - and ${ }^{13} \mathrm{C}$ NMR data were consistent with those previously reported. ${ }^{8}$

CAUTION: Although no toxicological data is available for the product, similar compounds (e.g. 2ethyloxirane) are suspected carcinogens. Furthermore, the intermediate 2-bromo-1cyclohexylethanone is a lacrimator. Handle both compounds in fume cupboard only.

[*] We advise to use a rotary evaporator, which is positioned in a fume hood. Some of the volatile product can evaporate with the solvent.

$\left[{ }^{* *}\right]$ For the distillation a diaphragm pump positioned in fume hood was used to avoid exposure to the product.

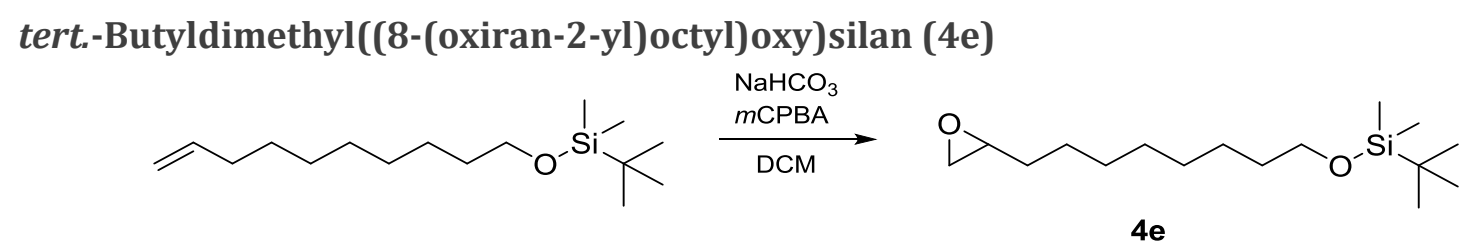

To a solution of tert-butyl(dec-9-en-1-yloxy)dimethylsilane ${ }^{9}(1.004 \mathrm{~g}, 3.70 \mathrm{mmol})$ in DCM $(30 \mathrm{~mL})$ were added $\mathrm{NaHCO}_{3}(1.56 \mathrm{~g}, 18.5 \mathrm{mmol})$ and $m$ CPBA $(957 \mathrm{mg}, 5.54 \mathrm{mmol})$ at rt and the reaction mixture was stirred overnight. An aq. solution of $\mathrm{Na}_{2} \mathrm{~S}_{2} \mathrm{O}_{3}(5 \%, 30 \mathrm{~mL})$ was added at $0{ }^{\circ} \mathrm{C}$ over the course of five minutes, after which stirring was continued at rt for $15 \mathrm{~min}$. The phases were separated,

\footnotetext{
${ }^{8}$ Huang, K.; Wang, H.; Stepanenko, V.; De Jesús, M.; Torruellas, C.; Correa, W.; Ortiz-Marciales, M. J. Org. Chem. 2011, 76, 1883-1886.
} 


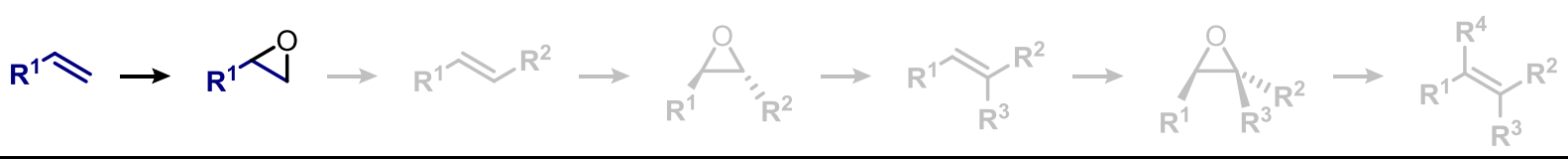

and the aqueous layer was extracted with $\mathrm{DCM}(2 \times 30 \mathrm{~mL})$. The combined organic layers were washed with a 1:1 mixture of brine and saturated aq. $\mathrm{NaHCO}_{3}$, dried over $\mathrm{MgSO}_{4}$ and concentrated in vacuo. Chromatography $\left(\mathrm{SiO}_{2}, \mathrm{CyHex}\right)$ yielded epoxide 4 e $(677 \mathrm{mg}, 2.36 \mathrm{mmol}, 64 \%)$ as a colorless oil.

$\mathbf{R}_{f}=0.22($ CyHex/EtOAc, 9:1).

${ }^{1}$ H NMR (300 MHz, CHLOROFORM-d) $\delta=3.59$ (t, J=6.6 Hz, $2 \mathrm{H}$ ), $2.86-2.94$ (m, $1 \mathrm{H}$ ), 2.74 (dd, $J=5.2$, $3.9 \mathrm{~Hz}, 1 \mathrm{H}), 2.46$ (dd, J=5.0, $2.8 \mathrm{~Hz}, 1 \mathrm{H}), 1.21-1.58(\mathrm{~m}, 14 \mathrm{H}), 0.89(\mathrm{~s}, 9 \mathrm{H}), 0.03(\mathrm{~s}, 6 \mathrm{H})$ ppm.

${ }^{13}$ C NMR (CHLOROFORM-d, 75 MHz): $\delta=63.3,52.4,47.1,32.9,32.5,30.9,29.5,29.3,26.0,25.8$, 18.4, -5.3 ppm.

${ }^{1} \mathrm{H}$ - and ${ }^{13} \mathrm{C} N M R$ data were consistent with those previously reported. ${ }^{9}$

\section{2-(8-(0xiran-2-yl)octyl)isoindolin-1,3-dion (4f)}
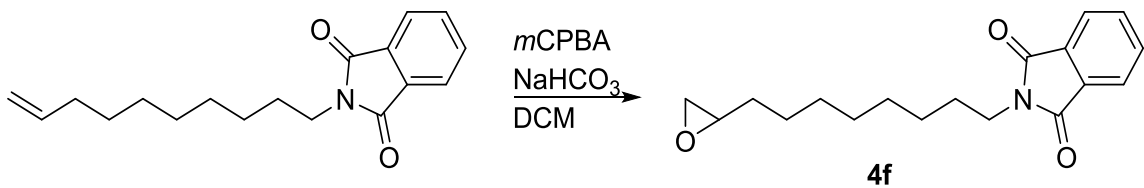

To a solution of 1-phthalimidodec-9-en ${ }^{10}$ (816 mg, $\left.2.86 \mathrm{mmol}\right)$ in DCM (40 mL) were added $\mathrm{NaHCO}_{3}$ (752 mg, $9 \mathrm{mmol})$ and $\mathrm{mCPBA}(795 \mathrm{mg}, 4.6 \mathrm{mmol}$ ) at $\mathrm{rt}$ and the reaction mixture was stirred overnight. An aq. solution of $\mathrm{Na}_{2} \mathrm{~S}_{2} \mathrm{O}_{3}(5 \%, 30 \mathrm{~mL})$ was added at $0{ }^{\circ} \mathrm{C}$ over the course of five minutes, after which stirring was continued at $\mathrm{rt}$ for $15 \mathrm{~min}$. The phases were separated, and the aqueous layer was extracted with DCM $(2 \times 30 \mathrm{~mL})$. The combined organic layers were washed with a 1:1 mixture of brine and saturated aq. $\mathrm{NaHCO}_{3}(30 \mathrm{~mL})$, dried over $\mathrm{MgSO}_{4}$ and concentrated in vacuo. Chromatography $\left(\mathrm{SiO}_{2}, \mathrm{CyHex} /\right.$ EtOAc 9:1) yielded epoxide $\mathbf{4 f}(644 \mathrm{mg}, 2.03 \mathrm{mmol}, 71 \%)$ as a colorless oil, containing $16 \%$ CyHex.

$\mathbf{R}_{f}=0.10($ CyHex/EtOAc, 9:1),

${ }^{1}$ H NMR (300 MHz, CHLOROFORM-d) $\delta=7.80-7.87(\mathrm{~m}, 2 \mathrm{H}), 7.67-7.74(\mathrm{~m}, 2 \mathrm{H}), 3.67$ (t, J=6.9 Hz, $2 \mathrm{H}$ ), 2.88 (ddt, J=5.5, 4.0, 2.6 Hz, $1 \mathrm{H}$ ), 2.73 (dd, J=5.0, 3.8 Hz, $1 \mathrm{H}), 2.45$ (dd, J=5.2, $2.7 \mathrm{~Hz}, 1 \mathrm{H}$ ), 1.67 (t, J=7.04 Hz, 2 H), $1.27-1.59$ (m, 12 H) ppm.

${ }^{13}$ C NMR (75 MHz, CHLOROFORM-d) $\delta=143.6,139.8,130.8,128.3,126.5,126.5,32.0,29.9,29.8$, 29.6, 29.4, 28.9, 22.8, 22.0, 14.6, $14.2 \mathrm{ppm}$.

IR: $\tilde{\mathrm{v}}=2927$ (m, br), 2848 (m), 2159 (w, br), 1770, (m), $1694(\mathrm{~s}), 1611(\mathrm{w}), 1464(\mathrm{~m}), 1431$ (m), 1398 (m), $1188(\mathrm{w}), 1055(\mathrm{~m}), 875(\mathrm{~m}), 718(\mathrm{~s}) \mathrm{cm}^{-1}$.

MS m/z $\left(\mathrm{ESI}^{+}\right): 324.2\left(\mathrm{M}+\mathrm{Na}^{+}, 100 \%\right), 242.2\left(\mathrm{M}+\mathrm{Na}^{+}+\mathrm{H}_{2} \mathrm{O}, 24 \%\right), 356.2\left(\mathrm{M}+\mathrm{Na}^{+}+\mathrm{MeOH}, 18 \%\right)$.

HR-MS m/z (ESI $\left.{ }^{+}\right)$: found: $\left[\mathrm{M}+\mathrm{H}^{+}\right]$302.1759, $\mathrm{C}_{12} \mathrm{H}_{23} \mathrm{NO}_{3} \mathrm{Na}$ calculated 302.1751 and $\left[\mathrm{M}+\mathrm{Na}^{+}\right]$ 324.1579, $\mathrm{C}_{12} \mathrm{H}_{23} \mathrm{NO}_{3} \mathrm{Na}$ calculated: 324.1570.

\footnotetext{
${ }^{9}$ L. Balas, J. Bertrand-Michel, F. Viars, J. Faugere, C. Lefort, S. Caspar-Bauguil, D. Langin, T. Durand, Org. \& Biomol. Chem. 2016, 14, 9012-9020.

${ }^{10}$ C. Hirschhäuser, J. Velcicky, D. Schlawe, E. Hessler, A. Majdalani, J.-M. Neudörfl, A. Prokop*, T. Wieder, H.-G. Schmalz*, Chem. Eur. J. 2013, 19, 13017-13029.
} 


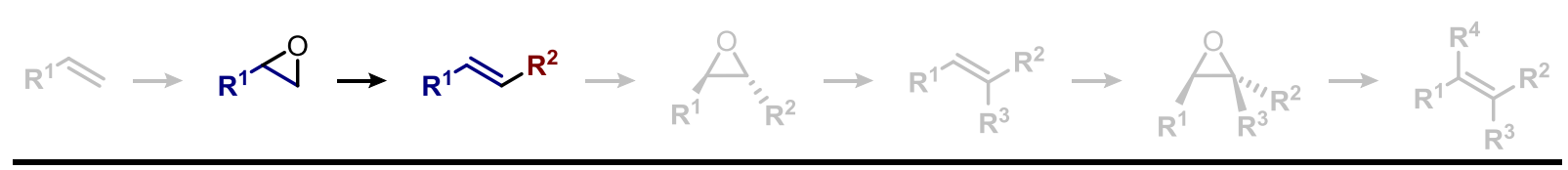

Synthesis of Disubstituted Alkenes

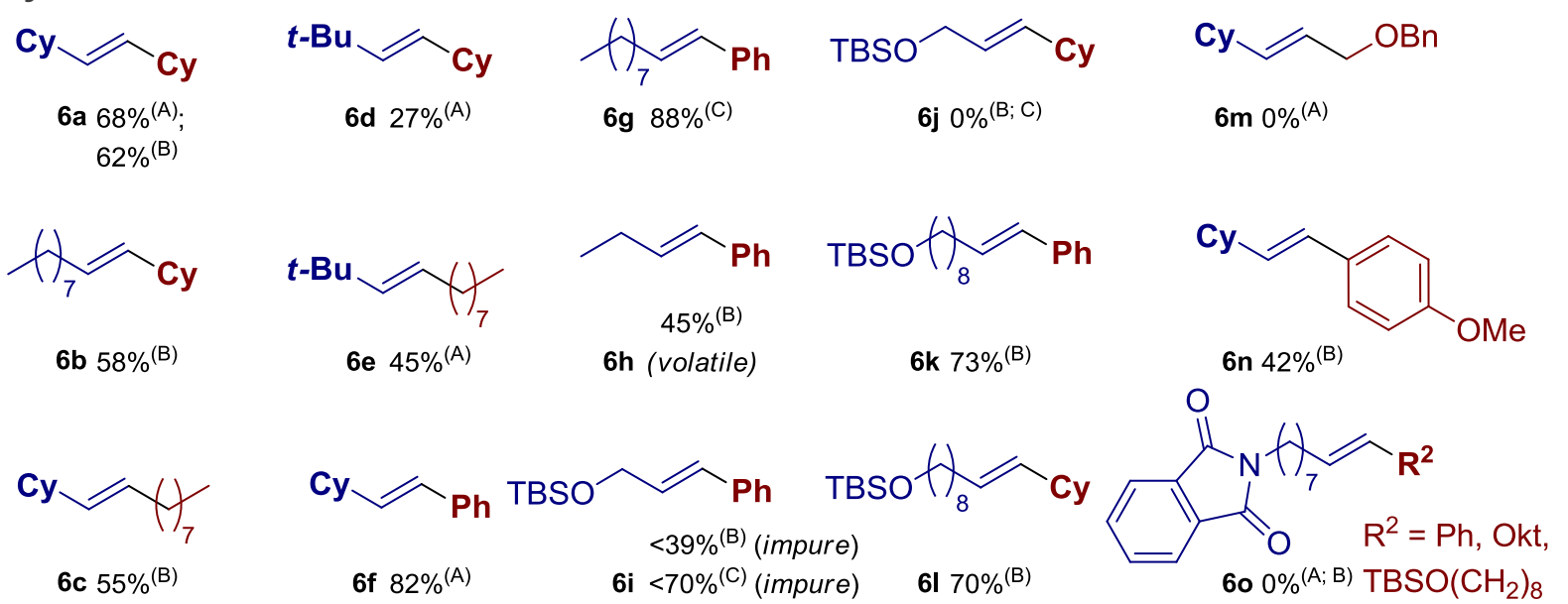

General Procedure GP1: Synthesis of Disubstituted Alkenes

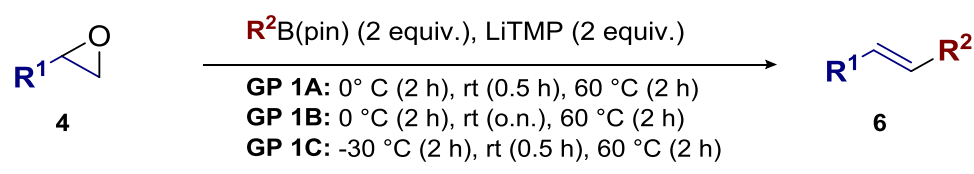

A solution of LiTMP was freshly prepared in a dried Schlenk tube by addition of $n B$ Bui in hexanes (2 equiv.) to 2,2,6,6-tetramethylpiperidin (TMP, 2.2 equiv.) in dry THF $(1.7-2.1 \mathrm{~mL} / \mathrm{mmol}$ of epoxide 4) at $0{ }^{\circ} \mathrm{C}$ and stirring for $30 \mathrm{~min}$ at rt. This LiTMP solution was added dropwise to an equal volume solution of epoxide 4 (1 equiv.) and boronic ester (2.0 equiv.) in dry THF (3.5 - $4.7 \mathrm{~mL} / \mathrm{mmol}$ of epoxide 4) at $0{ }^{\circ} \mathrm{C}$ (GP1A and 1B) or $-30{ }^{\circ} \mathrm{C}$ (GP1C). Stirring was continued for $2 \mathrm{~h}$ at the same temperature. The reaction mixture was allowed to warm up to room temperature for $30 \mathrm{~min}$ (GP1A and 1C) or overnight (GP1B) before the reaction mixture was heated to $60^{\circ} \mathrm{C}$ for $2 \mathrm{~h} \cdot{ }^{[*]}$ The reaction mixture was cooled to room temperature, transferred into a separation funnel with the help of $\mathrm{Et}_{2} \mathrm{O}$ and washed $(3 \mathrm{x})$ with $\mathrm{NaOH}(1 \mathrm{M}) .{ }^{[* *]}$ The combined aqueous layers were re-extracted with $\mathrm{Et}_{2} \mathrm{O}(2 \mathrm{x})$. The combined organic layers were dried with $\mathrm{Na}_{2} \mathrm{SO}_{4}$ and concentrated in vacuo. The residue was purified by column chromatography.

Comments: ${ }^{[*]}$ The difference between GP1A and GP1B, i.e. whether the reaction is warmed up to room temperature for $30 \mathrm{~min}$ or overnight respectively, is a matter of convenience. For comparison $\mathbf{6 a}$ $\left(R^{1}=R^{2}=\right.$ Cy) was prepared according to GP1A and GP1B with $68 \%$ and $62 \%$ yield, respectively. ${ }^{[* *]}$ When necessary, brine was added to aid phase separation.

Sample Procedure: A solution of LiTMP was prepared by addition of $n \mathrm{BuLi}$ in hexanes $(2.8 \mathrm{~mL}$,

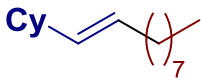
$4.49 \mathrm{mmol}, 1.55 \mathrm{~mol} / \mathrm{L})$ to 2,2,6,6-tetramethylpiperidin $(0.83 \mathrm{~mL}, 5.39 \mathrm{mmol})$ in dry THF $(6 \mathrm{~mL})$ at $0{ }^{\circ} \mathrm{C}$. After stirring for $0.5 \mathrm{~h}$ at room temperature, this mixture was added dropwise to a solution 6 c $55 \%{ }^{(B)}$ of epoxide $4 \mathrm{a}(280 \mathrm{mg}, 2.25 \mathrm{mmol})$ and octylboronic acid pinacol ester $(1.08 \mathrm{~g}, 4.49 \mathrm{mmol})$ stirred at $0{ }^{\circ} \mathrm{C}$ in dry THF $(8 \mathrm{~mL})$. Stirring at $0{ }^{\circ} \mathrm{C}$ was continued for $2 \mathrm{~h}$. The reaction mixture was allowed to warm up to room temperature overnight, after which the reaction mixture was heated to $60{ }^{\circ} \mathrm{C}$ for $2 \mathrm{~h}$. The reaction mixture was cooled to room temperature, transferred into a separation funnel with $\mathrm{Et}_{2} \mathrm{O}$ and washed with aq. $\mathrm{NaOH}(1 \mathrm{M}, 2 \times 50 \mathrm{~mL})$ and brine $(50 \mathrm{~mL})$. The combined aqueous layers were re-extracted with $\mathrm{Et}_{2} \mathrm{O}(2 \times 50 \mathrm{~mL})$. The combined organic layers were dried with $\mathrm{Na}_{2} \mathrm{SO}_{4}$ and concentrated in vacuo. Column chromatography $\left(\mathrm{SiO}_{2}\right.$, CyHex/EtOAc, 19:1) afforded alkene $6 \mathbf{c}(272 \mathrm{mg}, 1.23 \mathrm{mmol}, 55 \%)$ as a colorless oil. $\mathbf{R}_{\boldsymbol{f}}=$ 0.72 (CyHex/EtOAc, 19:1). ${ }^{1} \mathrm{H}$ NMR (300 MHz, CHLOROFORM- $d$ ) $\delta=5.27-5.42(\mathrm{~m}, 2 \mathrm{H}), 1.85-2.02(\mathrm{~m}, 3 \mathrm{H})$, $1.59-1.74(\mathrm{~m}, 5 \mathrm{H}), 0.80-1.40(\mathrm{~m}, 20 \mathrm{H})$ ppm. ${ }^{13} \mathrm{C}$ NMR $(75 \mathrm{MHz}, \mathrm{CHLOROFORM}-\mathrm{d}): \delta=136.4,127.8,40.7$, 33.3, 32.7, 31.9, 29.7, 29.5, 29.3, 29.1, 26.3, 26.2, 22.7, $14.1 \mathrm{ppm} .{ }^{1} \mathrm{H}$ - and ${ }^{13} \mathrm{C} N M R$ data were consistent with those previously reported. ${ }^{11}$

\footnotetext{
${ }^{11}$ G. Cahiez, O. Gager, J. Buendia, C. Patinote, Chem. Eur. J. 2012, 18, 5860-5863.
} 


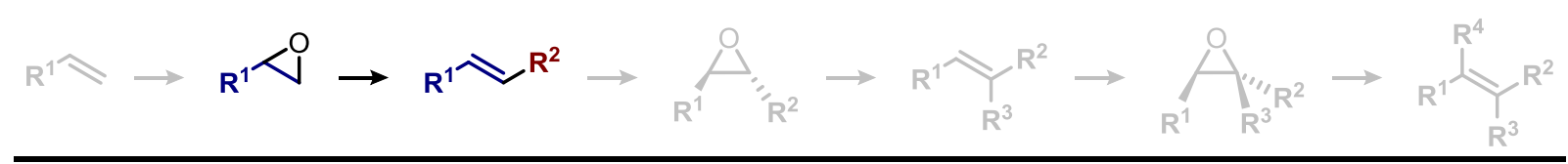

(E)-1,2-Dicyclohexylethene (6a)<smiles>[Ge]/C=C/[Ge]</smiles>

Following GP1A a solution of LiTMP $(0.88 \mathrm{mmol})$, was reacted with epoxide $4 \mathrm{~b}(0.40 \mathrm{mmol})$ and cyclohexyl pinacol boronic ester $(0.80 \mathrm{mmol})$ to yield $6 \mathrm{a}(52 \mathrm{mg}, 0.27 \mathrm{mmol}, 68 \%)$ as a colorless oil after chromatography $\left(\mathrm{SiO}_{2}, \mathrm{CyHex}\right)$.

$\mathbf{R}_{\mathbf{f}}=0.61$ (CyHex).

${ }^{1} \mathrm{H}$ NMR (300 MHz, CHLOROFORM-d) $\delta=5.30(\mathrm{dd}, J=3.60,1.72 \mathrm{~Hz}, 2 \mathrm{H}), 0.93-1.92(\mathrm{~m}, 22 \mathrm{H}) \mathrm{ppm}$.

${ }^{13} \mathrm{C}$ NMR $(75 \mathrm{MHz}$, CHLOROFORM-d) $\delta=133.8,40.7,33.4,26.3,26.2 \mathrm{ppm}$.

${ }^{1} \mathrm{H}$ - and ${ }^{13} \mathrm{C}$ NMR data were consistent with those previously reported. ${ }^{12}$

(E)-Dec-1-en-1-ylcyclohexan (6b/6c)

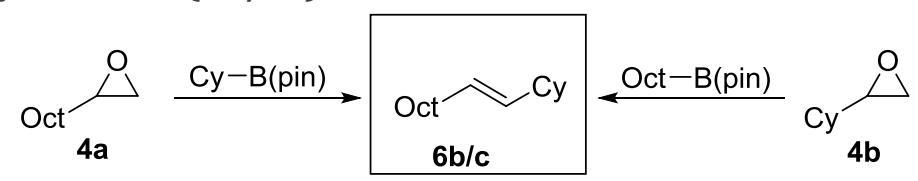

Following GP1B a solution of LiTMP $(0.88 \mathrm{mmol})$, was reacted with epoxide $4 \mathrm{a}(0.40 \mathrm{mmol})$ and cyclohexyl pinacol boronic ester $(0.80 \mathrm{mmol})$ to yield $6 \mathrm{~b}(51 \mathrm{mg}, 0.27 \mathrm{mmol}, 58 \%)$ as a colorless oil after chromatography $\left(\mathrm{SiO}_{2}, \mathrm{CyHex} / \mathrm{EtOAc}, 19: 1\right)$.

Following GP1B a solution of LiTMP (4.95 mmol), was reacted with epoxide $4 \mathbf{b}(2.25 \mathrm{mmol})$ and octyl pinacol boronic ester $(4.50 \mathrm{mmol})$ to yield $6 \mathrm{c}(272 \mathrm{mg}, 1.22 \mathrm{mmol}, 55 \%)$ as a colorless oil after

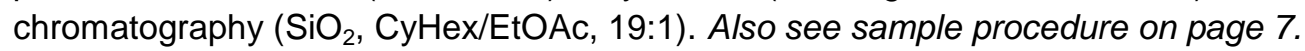

$\mathbf{R}_{f}=0.72($ CyHex/EtOAc, 19:1).

${ }^{1}$ H NMR (300 MHz, CHLOROFORM- $\left.d\right) \delta=5.27-5.42(\mathrm{~m}, 2 \mathrm{H}), 1.85-2.02(\mathrm{~m}, 3 \mathrm{H}), 1.59-1.74(\mathrm{~m}$, $5 \mathrm{H}), 0.80-1.40(\mathrm{~m}, 20 \mathrm{H}) \mathrm{ppm}$.

${ }^{13} \mathrm{C}$ NMR $(75 \mathrm{MHz}$, CHLOROFORM- $d): \delta=136.4,127.8,40.7,33.3,32.7,31.9,29.7,29.5,29.3,29.1$, 26.3, 26.2, 22.7, $14.1 \mathrm{ppm}$.

${ }^{1} \mathrm{H}$ - and ${ }^{13} \mathrm{C}$ NMR data were consistent with those previously reported. ${ }^{13}$

\footnotetext{
${ }^{12}$ G. Opitz, T. Ehlis, K. Rieth, Chem. Ber. 1990, 123, 1989-1998.

${ }^{13}$ G. Cahiez, O. Gager, J. Buendia, C. Patinote, Chem. Eur. J. 2012, 18, 5860-5863.
} 


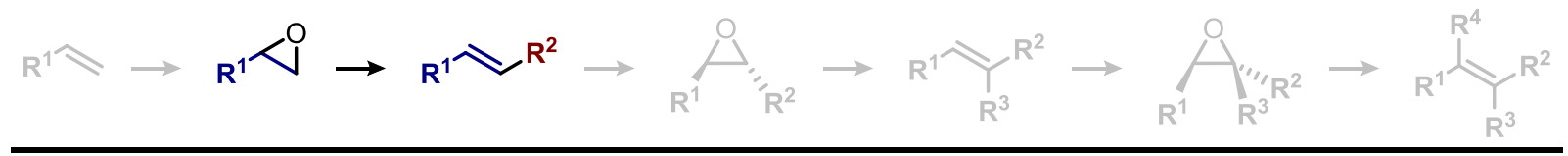

(E)-3,3-Dimethyl-1-buten-1-ylcyclohexan (6d)

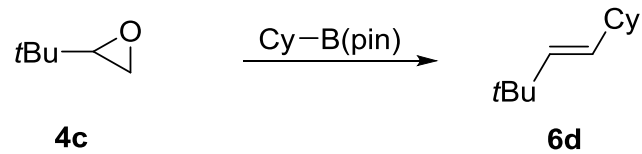

Following GP1B a solution of LiTMP $(5.24 \mathrm{mmol})$, was reacted with epoxide $4 \mathrm{c}(2.38 \mathrm{mmol})$ and cyclohexyl pinacol boronic ester $(4.76 \mathrm{mmol})$ to yield $6 \mathbf{d}(173 \mathrm{mg}, 0.64 \mathrm{mmol}, 27 \%)$ as a colorless oil

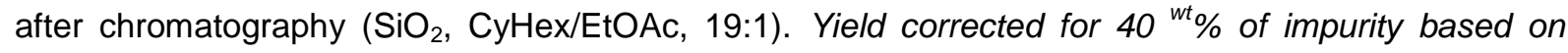
subsequent transformations.

$\mathbf{R}_{\mathbf{f}}=0.71($ Cyhex/EtOAc, 9:1).

${ }^{1} \mathrm{H}-\mathrm{NMR}\left(300 \mathrm{MHz}, \mathrm{CDCl}_{3}\right): \delta=0.97(\mathrm{~s}, 9 \mathrm{H}), 1.05-1.80(\mathrm{~m}, 11 \mathrm{H}), 5.25(\mathrm{dd}, J=15.6,6.6 \mathrm{~Hz}, 1 \mathrm{H})$, $5.36(\mathrm{~d}, J=15.6,1 \mathrm{H}) \mathrm{ppm}$.

${ }^{13} \mathrm{C}-\mathrm{NMR}\left(75 \mathrm{MHZ}, \mathrm{CDCl}_{3}\right): \delta=138.9,130.8,40.7,33.4,32.5,26.9,26.3,26.3 \mathrm{ppm}$.

${ }^{1} \mathrm{H}$ - and ${ }^{13} \mathrm{C}$ NMR data were consistent with those previously reported. ${ }^{14}$

\section{(E)-2,2-Dimethyl-3-dodecen (6e)}

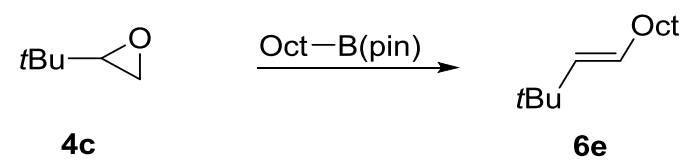

Following GP1B a solution of LiTMP $(0.88 \mathrm{mmol})$, was reacted with epoxide $4 \mathrm{c}(0.40 \mathrm{mmol})$ and octyl pinacol boronic ester $(0.80 \mathrm{mmol})$ to yield $6 \mathrm{e}(35 \mathrm{mg}, 0.18 \mathrm{mmol}, 45 \%)$ as a colorless oil after chromatography $\left(\mathrm{SiO}_{2}\right.$, CyHex/EtOAc, 19:1).

$\mathbf{R}_{\mathbf{f}}=0.67($ Cyhex/EtOAc, 9:1).

${ }^{1} \mathrm{H}-\mathrm{NMR}\left(300 \mathrm{MHz}, \mathrm{CDCl}_{3}\right): \delta=5.25-5.46(\mathrm{~m}, 2 \mathrm{H}), 1.93-1.99(\mathrm{~m}, 2 \mathrm{H}), 1.26(\mathrm{~m}, 12 \mathrm{H}), 0.98(\mathrm{~s}, 9 \mathrm{H})$, 0.88 (t, $J=6.87 \mathrm{~Hz}, 3 \mathrm{H}$ ), ppm.

${ }^{13} \mathrm{C}-\mathrm{NMR}\left(75 \mathrm{MHZ}, \mathrm{CDCl}_{3}\right): \delta=141.4,124.8,32.7,31.9,29.8,29.7,29.5,29.4,29.3,29.1,22.7,14.1$ ppm.

${ }^{1} \mathrm{H}$ - and ${ }^{13} \mathrm{C}$ NMR data were consistent with those previously reported. ${ }^{15}$

\footnotetext{
${ }^{14}$ T. M. Yuan, T. Y. Luh, J. Org. Chem. 1992, 57, 4550-4552.

${ }^{15}$ First report of compound: G.H. Posner, K.A. Babiak, J. Organomet. Chem. 1979, 177, 299-307. NMR Data was compared to the octen-congener. G. Cahiez, H. Avedissian, Synthesis 1998, 1998, 1199-1205.
} 


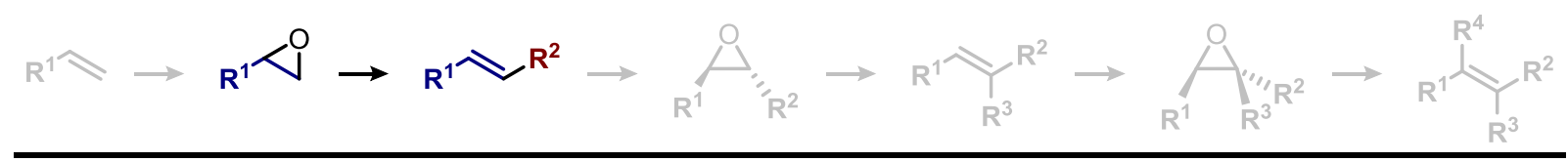

(E)-(2-Cyclohexylvinyl)benzen (6f)

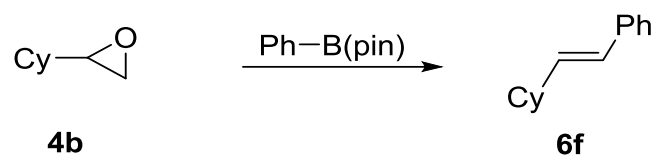

Following GP1A a solution of LiTMP $(0.88 \mathrm{mmol})$, was reacted with epoxide $4 \mathrm{~b}(0.46 \mathrm{mmol})$ and phenyl pinacol boronic ester $(0.80 \mathrm{mmol})$ to yield $6 \mathbf{f}(70 \mathrm{mg}, 0.38 \mathrm{mmol}, 82 \%)$ as a colorless oil after chromatography $\left(\mathrm{SiO}_{2}, \mathrm{CyHex}\right)$.

$\mathbf{R}_{f}=0.38$ (CyHex).

${ }^{1}$ H-NMR (300 MHz, CHLOROFORM- $d$ ) $\delta=7.23-7.44(\mathrm{~m}, 4 \mathrm{H}), 7.09-7.22(\mathrm{~m}, 1 \mathrm{H}), 6.35(\mathrm{~d}, \mathrm{~J}=15.6$ $\mathrm{Hz}, 1 \mathrm{H}), 6.18(\mathrm{dd}, \mathrm{J}=15.9,6.9 \mathrm{~Hz}, 1 \mathrm{H}), 2.02-2.26(\mathrm{~m}, 1 \mathrm{H}), 1.61-1.88(\mathrm{~m}, 4 \mathrm{H}), 1.09-1.45 \mathrm{ppm}(\mathrm{m}$, $4 \mathrm{H}) \mathrm{ppm}$.

${ }^{13} \mathrm{C}$ NMR $(75 \mathrm{MHz}$, CHLOROFORM- $d) \delta=138.22,137.02,128.60,127.37,126.87,126.09,41.31$, $33.12,26.34,26.20 \mathrm{ppm}$.

${ }^{1} \mathrm{H}$ - and ${ }^{13} \mathrm{C}$ NMR data were consistent with those previously reported. ${ }^{16}$

Comment: Prolonged heating at $60^{\circ} \mathrm{C}$ lead to a reduction in yield in this case, probably due to decomposition of the styrene derivative.

(E)-Dec-1-en-1-ylbenzen $(6 \mathrm{~g})$

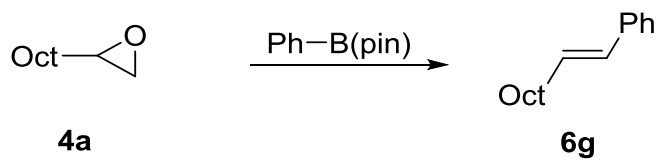

Following GP1C a solution of LiTMP $(0.70 \mathrm{mmol})$, was reacted with epoxide $4 \mathrm{a}(0.35 \mathrm{mmol})$ and phenyl pinacol boronic ester $(0.64 \mathrm{mmol})$ to yield $6 \mathrm{~g}(67 \mathrm{mg}, 0.31 \mathrm{mmol}, 88 \%)$ as a colorless oil after chromatography $\left(\mathrm{SiO}_{2}\right.$, CyHex/EtOAc, 19:1).

$\mathbf{R}_{f}=0.62($ CyHex/EtOAc, 19:1).

${ }^{1}$ H NMR $(300 \mathrm{MHz}$, CHLOROFORM- $d) \delta=7.27-7.38(\mathrm{~m}, 4 \mathrm{H}), 7.14-7.22(\mathrm{~m}, 1 \mathrm{H}), 6.38(\mathrm{~d}, \mathrm{~J}=16.3$ $\mathrm{Hz}, 1 \mathrm{H}), 6.16-6.29(\mathrm{~m}, 1 \mathrm{H}), 2.15-2.26(\mathrm{~m}, 2 \mathrm{H}), 1.41-1.53(\mathrm{~m}, 2 \mathrm{H}), 1.17-1.40(\mathrm{~m}, 10 \mathrm{H}), 0.80-$ $0.95(\mathrm{~m}, 3 \mathrm{H}) \mathrm{ppm}$.

${ }^{13} \mathrm{C}$ NMR $(75 \mathrm{MHz}$, CHLOROFORM- $d) \delta=138.1,131.4,129.8,128.6,126.9,126.1,33.2,32.1,29.7$, 29.6, 29.5, 29.4, 22.8, $14.3 \mathrm{ppm}$.

${ }^{1} \mathrm{H}$ - and ${ }^{13} \mathrm{C}$ NMR data were consistent with those previously reported. ${ }^{17}$

\footnotetext{
${ }^{16}$ M. J. Rawling, J. H. Rowley, M. Campbell, A. R. Kennedy, J. A. Parkinson, N. C. O. Tomkinson, Chem. Sci. 2014, 5, 17771785.

${ }^{7}$ P. Andrews, C. M. Latham, M. Magre, D. Willcox, S. Woodward, Chem. Comm. 2013, 49, 1488.
} 


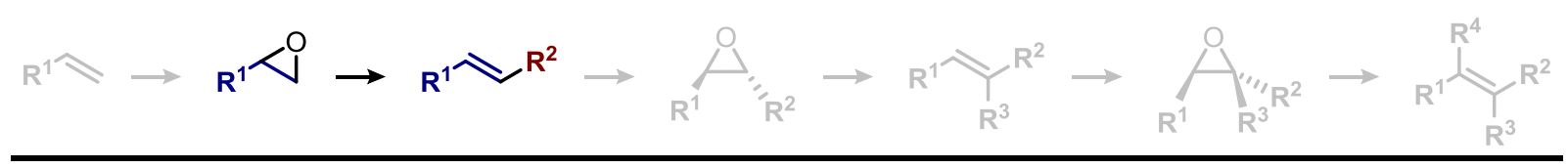

(E)-But-1-en-1-ylbenzen (6h)

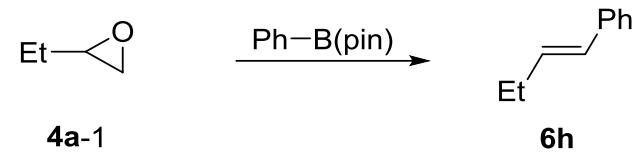

Following GP1B a solution of LiTMP (10.78 mmol), was reacted with epoxide 4a-1 $(4.90 \mathrm{mmol})$ and phenyl pinacol boronic ester $(9.80 \mathrm{mmol})$ to yield $6 \mathrm{~h}(393 \mathrm{mg}, 2.97 \mathrm{mmol}, 54 \%)$ as a colorless oil after chromatography $\left(\mathrm{SiO}_{2}, \mathrm{CyHex}\right)$.

$\mathbf{R}_{f}=0.50($ CyHex/EtOAc, 19:1).

${ }^{1}$ H NMR (300 MHz, CHLOROFORM- $\left.d\right) \delta=7.21-7.35(\mathrm{~m}, 4 \mathrm{H}), 7.12-7.20(\mathrm{~m}, 1 \mathrm{H}), 6.36(\mathrm{~d}, \mathrm{~J}=16.0$ $\mathrm{Hz}, 1 \mathrm{H}), 6.18-6.29(\mathrm{~m}, 1 \mathrm{H}), 2.14-2.27(\mathrm{~m}, 2 \mathrm{H}), 1.07$ (t, J=7.3 Hz, $3 \mathrm{H}) \mathrm{ppm}$.

${ }^{13} \mathrm{C}$ NMR (75 MHz, CHLOROFORM- $d$ ) $\delta=138.12,132.80,128.96,128.62,126.89,126.06,26.21$, $13.81 \mathrm{ppm}$.

${ }^{1} \mathrm{H}$ NMR data was consistent with a previous report. ${ }^{18}$

Comment: The reaction was conducted several times on different scales and isolated yields varied considerably as the product is volatile.

tert.-Butyl(cinnamyloxy)dimethylsilan (6i)<smiles>[SbH3]OCC1CO1</smiles>

4d

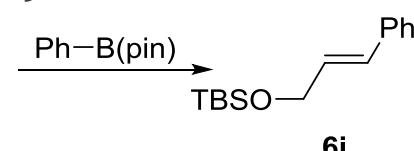

$6 \mathbf{i}$

Following GP1C a solution of LiTMP $(0.66 \mathrm{mmol})$, was reacted with epoxide $\mathbf{4 d}(0.30 \mathrm{mmol})$ and phenyl pinacol boronic ester $(0.53 \mathrm{mmol})$ to yield $6 \mathbf{i}(53 \mathrm{mg},<0.21 \mathrm{mmol},<70 \%)$ as a colorless oil after chromatography $\left(\mathrm{SiO}_{2}\right.$, CyHex/EtOAc, 19:1). The product contained a R-OTBS type impurity, which could not be removed by repeated chromatography. NMR signals were obtained from mixture (see appendix for spectra).

$\mathbf{R}_{f}=0.40($ CyHex/EtOAc, 19:1).

'H-NMR (300 MHz, CHLOROFORM- $d$ ): $\delta=7.21-7.41(\mathrm{~m}, 5 \mathrm{H}), 6.59(\mathrm{~d}, \mathrm{~J}=16.0 \mathrm{~Hz}, 1 \mathrm{H}), 6.29$ (dt, $J=15.0,5.0 \mathrm{~Hz}, 1 \mathrm{H}), 4.36$ (dd, J=5.0, $1.6 \mathrm{~Hz}, 2 \mathrm{H}), 0.95$ (s, $9 \mathrm{H}), 0.12$ (s, $6 \mathrm{H}) \mathrm{ppm}$.

${ }^{13} \mathrm{C}$ NMR $(75 \mathrm{MHz}$, CHLOROFORM- $d) \delta=137.1,129.5,129.2,128.5,127.3,126.4,63.9,26.0,18.4$, $5.1 \mathrm{ppm}$.

${ }^{1} \mathrm{H}$ - and ${ }^{13} \mathrm{C}$ NMR data were consistent with those previously reported ${ }^{19}$

\footnotetext{
${ }^{18} \mathrm{~J}$. Li, J. Peng, Y. Bai, L. Chen, G. Lai, Phosphorus Sulfur 2011, 186, 1621-1625.

19 J. J. Loman, V. A. Pistritto, C. B. Kelly, N. E. Leadbeater, Synlett 2016, 27, 2372-2377.
} 


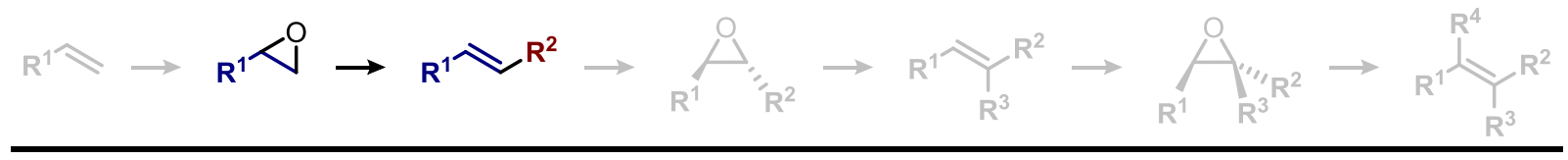

(E)-tert.-Butyldimethyl((10-phenyldec-9-en-1-yl)oxy)silan (6k)

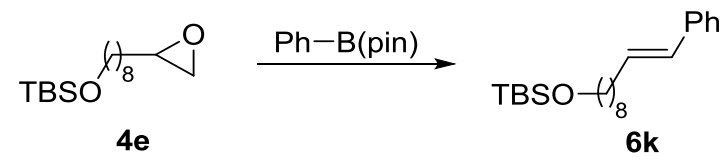

Following GP1B a solution of LiTMP (0.88 mmol), was reacted with epoxide $4 \mathrm{e}(0.41 \mathrm{mmol})$ and phenyl pinacol boronic ester $(0.80 \mathrm{mmol})$ to yield $6 \mathbf{k}(104 \mathrm{mg}, 0.31 \mathrm{mmol}, 75 \%)$ as a colorless oil after chromatography $\left(\mathrm{SiO}_{2}, \mathrm{CyHex}\right)$.

$\mathbf{R}_{\boldsymbol{f}}=0.58$ (CyHex/EtOAc, 19:1).

${ }^{1}$ H NMR $(300 \mathrm{MHz}$, CHLOROFORM- $d) \delta=7.24-7.37(\mathrm{~m}, 4 \mathrm{H}), 7.14-7.22(\mathrm{~m}, 1 \mathrm{H}), 6.38(\mathrm{~d}, \mathrm{~J}=15.6$ $\mathrm{Hz}, 1 \mathrm{H}), 6.17-6.28(\mathrm{~m}, 1 \mathrm{H}), 3.56-3.64(\mathrm{t}, 2 \mathrm{H}), 2.15-2.27(\mathrm{~m}, 2 \mathrm{H}), 1.41-1.59(\mathrm{~m}, 2 \mathrm{H}), 1.23-1.41$ $(\mathrm{m}, 10 \mathrm{H}), 0.87-0.98(\mathrm{~m}, 9 \mathrm{H}), 0.03-0.12(\mathrm{~m}, 6 \mathrm{H}) \mathrm{ppm}$.

${ }^{13} \mathrm{C}-\mathrm{NMR}(75 \mathrm{MHz}$, CHLOROFORM- $d) \delta=138.0,131.2,129.7,128.4,126.7,125.9,63.3,33.0,32.9$, $29.5,29.4,29.4,29.2,26.0,25.8,18.4,-5.3 \mathrm{ppm}$.

IR: $\tilde{v}=2925(m), 2854(m), 2160(w), 2027$ (w, br.), 1973 (w, br.), $1458(m), 1254(m), 1095$ (s), 962 (m), $833(\mathrm{~s}), 773(\mathrm{~s}), 741(\mathrm{~m}), 690(\mathrm{~m}) \mathrm{cm}^{-1}$.

HR-MS m/z $\left(\mathrm{ESI}^{+}\right)$: found: $\left[\mathrm{M}+\mathrm{H}^{+}\right]$347.2767, $\mathrm{C}_{22} \mathrm{H}_{38} \mathrm{OSiH}$ calculated 347.2765 and $\left[\mathrm{M}+\mathrm{Na}^{+}\right]$369.2587, $\mathrm{C}_{22} \mathrm{H}_{38} \mathrm{OSiNa}$ calculated 369.2584.

(E)-tert.-Butyl((10-cyclohexyldec-9-en-1-yl)oxy)dimethylsilan (6l)

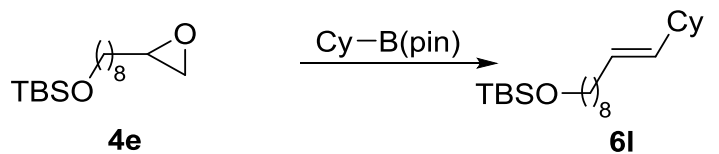

Following GP1B a solution of LiTMP $(0.88 \mathrm{mmol})$, was reacted with epoxide $4 \mathrm{e}(0.40 \mathrm{mmol})$ and cyclohexyl pinacol boronic ester $(0.80 \mathrm{mmol})$ to yield $6 \mathrm{l}(109 \mathrm{mg}, 0.31 \mathrm{mmol}, 77 \%)$ as a colorless oil after chromatography $\left(\mathrm{SiO}_{2}, \mathrm{CyHex}\right)$.

$\mathbf{R}_{f}=0.64($ CyHex/EtOAc, 19:1).

${ }^{1}$ H NMR (300 MHz, CHLOROFORM- $d$ ) $\delta=5.31-5.37(\mathrm{~m}, 2 \mathrm{H}), 3.60(\mathrm{t}, \mathrm{J}=6.57 \mathrm{~Hz}, 2 \mathrm{H}), 1.44-2.01$ $(\mathrm{m}, 11 \mathrm{H}), 0.96-1.39(\mathrm{~m}, 16 \mathrm{H}), 0.90(\mathrm{~s}, 9 \mathrm{H}), 0.06(\mathrm{~s}, 6 \mathrm{H}) \mathrm{ppm}$.

${ }^{13} \mathrm{C}-\mathrm{NMR}(75 \mathrm{MHz}, \mathrm{CHLOROFORM}-d) \delta=136.5,127.8,63.4,40.8,33.4,33.0,32.7,29.8,29.6,29.5$, $29.1,27.0,26.3,26.2,26.1,25.9,18.4,-5,0$ ppm.

IR: $\tilde{v}=2924(s), 2852(m), 1449(w), 2160(w), 2027$ (w, br.), $1977(w, b r),. 1506(w), 1458(w), 1253$ (m), $1097(\mathrm{~s}), 966(\mathrm{w}), 833(\mathrm{~s}), 773(\mathrm{~s}) \mathrm{cm}^{-1}$.

HR-MS m/z (ESI $\left.{ }^{+}\right)$: found: $\left[\mathrm{M}+\mathrm{H}^{+}\right]$353.3239, $\mathrm{C}_{22} \mathrm{H}_{44} \mathrm{OSiH}$ calculated: 353.3234 and $\left[\mathrm{M}+\mathrm{Na}^{+}\right]$375.3056, $\mathrm{C}_{22} \mathrm{H}_{38} \mathrm{OSiNa}$ calculated: 375.3054 . 


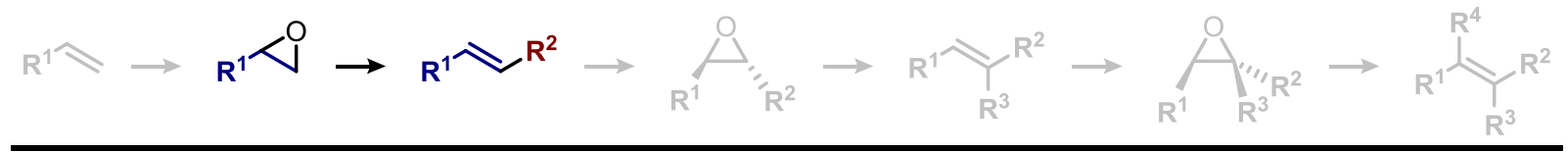

(E)-1-(2-Cyclohexylvinyl)-4-methoxybenzen (6n)

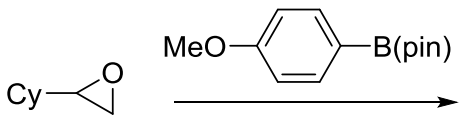

4b

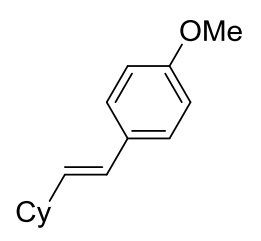

$6 n$

Following GP1B a solution of LiTMP $(1.76 \mathrm{mmol})$, was reacted with epoxide $\mathbf{4 b}(0.86 \mathrm{mmol})$ and ortho-methoxyphenyl pinacol boronic ester $(1.60 \mathrm{mmol})$ to yield $6 \mathrm{n}(75 \mathrm{mg}, 0.36 \mathrm{mmol}, 40 \%)$ as a yellow oil after chromatography $\left(\mathrm{SiO}_{2}, \mathrm{CyHex} / \mathrm{EtOAc}, 19: 1\right)$. The material obtained after chromatography contained $71 \%$ of $\mathbf{6 n}, 15.5 \%$ of boronic ester and $13.5 \%$ epoxide $\mathbf{4 b}$ starting material. The yield was corrected accordingly.

$\mathbf{R}_{f}=0.42($ CyHex/EtOAc, 19:1).

${ }^{1}$ H NMR (300 MHz, CHLOROFORM- $d$ ) $\delta=7.25-7.32(\mathrm{~m}, 2 \mathrm{H}), 6.81-6.87(\mathrm{~m}, 2 \mathrm{H}), 6.29(\mathrm{~d}, \mathrm{~J}=15.9$ $\mathrm{Hz}, 1 \mathrm{H}), 6.04(\mathrm{dd}, J=15.9,6.9 \mathrm{~Hz}, 1 \mathrm{H}), 3.80(\mathrm{~s}, 3 \mathrm{H}), 2.03-2.19(\mathrm{~m}, 1 \mathrm{H}), 1.62-1.93(\mathrm{~m}, 5 \mathrm{H}), 1.08-$ $1.43(\mathrm{~m}, 5 \mathrm{H}) \mathrm{ppm}$.

${ }^{13} \mathrm{C}$ NMR $(75 \mathrm{MHz}$, CHLOROFORM- $d) \delta=158.6,134.8,130.9,127.0,126.5,113.9,55.3,41.1,33.1$, 26.2, $26.1 \mathrm{ppm}$.

${ }^{1} \mathrm{H}$ - and ${ }^{13} \mathrm{C}$ NMR data were consistent with those previously reported. ${ }^{20}$ 


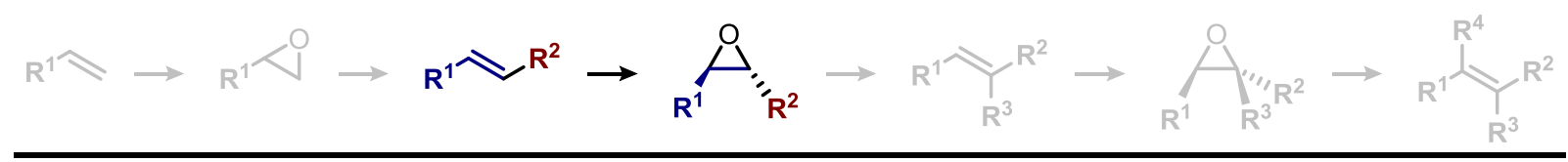

Synthesis/Sources of Disubstituted Epoxides

General Procedure GP2: Epoxidation of Di- and Trisubstituted Alkenes

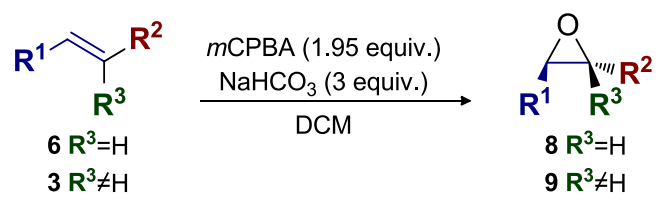

$\mathrm{NaHCO}_{3}$ (3 equiv.) and mCPBA (1.95 equiv.) were added to a solution of alkene in DCM (ca. $13 \mathrm{ml} / \mathrm{mmol}$ of alkene) and the mixture was stirred overnight at room temperature. Afterwards the reaction mixture was cooled to $0^{\circ} \mathrm{C}$ before an equal volume of aq. $\mathrm{Na}_{2} \mathrm{~S}_{2} \mathrm{O}_{3}(5 \%)$ was added. Stirring was continued for $5 \mathrm{~min}$. at $0{ }^{\circ} \mathrm{C}$ and $15 \mathrm{~min}$. at room temperature. The mixture was washed with equal volumes of brine, saturated aq. $\mathrm{NaHCO}_{3}$. The combined aqueous phases were re-extracted with $\operatorname{DCM}(3 x)$ and the combined organic extracts were dried over $\mathrm{MgSO}_{4}$. The solvent was removed in vacuo and the crude product was purified by column chromatography.

Comment: Although this is a known problem, ${ }^{21}$ it should be mentioned that such epoxides, which can open up and form stabilized cations, are particularly vulnerable to acid mediated epimerization. This tendency is reduced by the addition of base (here $\mathrm{NaHCO}_{3}$, which intercepts meta-chlorbenzoic acid) and no epimerization was observed for the compounds reported below. However, attempts to epoxidize e.g. $\mathbf{6} \boldsymbol{n}$ with this (and a comparable biphasic) ${ }^{22}$ system consistently led to epimerization.

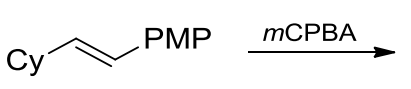

$6 n$

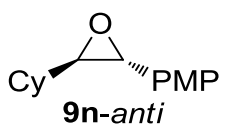<smiles>[C+]#[I+]</smiles>

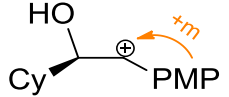<smiles>[C]1C=C1</smiles>

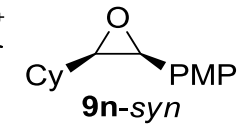

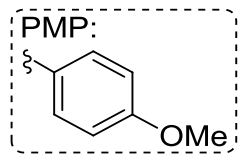

(2R,3R)-2-Ethyl-3-phenyloxiran (9a)<smiles>C/C=C/c1ccccc1</smiles><smiles>CC[C@H]1O[C@H]1P</smiles>

$6 h$

9a

According to GP2 alkene $6 \mathrm{~h}(210 \mathrm{mg}, 1.59 \mathrm{mmol})$ was transformed into epoxide 9a (180 $\mathrm{mg}, 1.21$ $\mathrm{mmol}, 76 \%)$, isolated as a colorless oil after column chromatography $\left(\mathrm{SiO}_{2}\right.$, CyHex/EtOAc 19:1).

$\mathbf{R}_{f}=0.42($ CyHex/EtOAc, 19:1).

${ }^{1}$ H-NMR (300 MHz, CHLOROFORM- $d$ ) $\delta=7.24-7.38(\mathrm{~m}, 5 \mathrm{H}), 3.63(\mathrm{~d}, \mathrm{~J}=2.2 \mathrm{~Hz}, 1 \mathrm{H}$ ), 2.95 (td, $J=5.5,2.2 \mathrm{~Hz}, 1 \mathrm{H}), 1.67-1.79(\mathrm{~m}, 2 \mathrm{H}), 1.07(\mathrm{t}, \mathrm{J}=7.5 \mathrm{~Hz}, 3 \mathrm{H}) \mathrm{ppm}$.

${ }^{13} \mathrm{C}$ NMR $(75 \mathrm{MHz}$, CHLOROFORM- $d) \delta=137.9,128.4,127.9,125.5,64.1,58.3,25.4,9.8 \mathrm{ppm}$.

${ }^{1} \mathrm{H}$ - and ${ }^{13} \mathrm{C}$ NMR data were consistent with those previously reported. ${ }^{23}$

\footnotetext{
${ }^{21}$ R. S. Mohan, K. Gavardinas, S. Kyere, D. L. Whalen, J. Org. Chem. 2000, 65, 1407-1413.

${ }_{22}^{2}$ G. Moyna, H. J. Williams, A. I. Scott, Synthetic Commun. 1996, 26, 2235-2239.

${ }^{23}$ H. Mang, J. Gross, M. Lara, C. Goessler, H. E. Schoemaker, G. M. Guebitz, W. Kroutil, Angew. Chem. Int. Edit. 2006, 45, 5201-5203.
} 


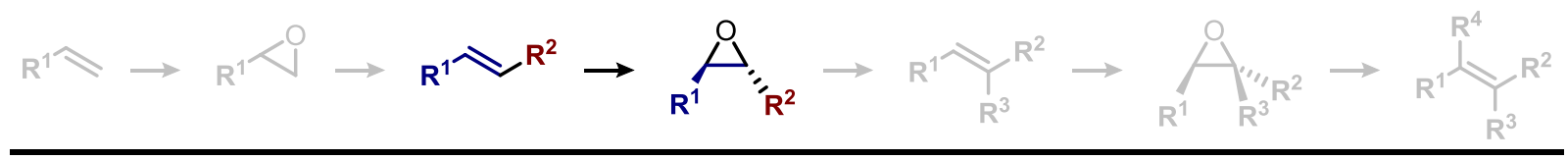

trans-2,3-Diphenyloxirane (9b-trans)

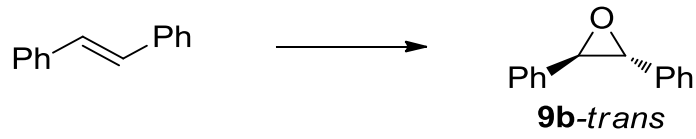

According to GP2 stilbene $(3.00 \mathrm{~g}, 16.6 \mathrm{mmol})$ was transformed into epoxide $9 \mathrm{~b}$-trans $(2.96 \mathrm{~g}$, $7.23 \mathrm{mmol}, 91 \%)$, isolated as a colorless oil after column chromatography $\left(\mathrm{SiO}_{2}\right.$, CyHex/EtOAc 30:1).

$\mathbf{R}_{f}=0.34($ CyHex/EtOAc, 19:1).

${ }^{1} \mathrm{H}-\mathrm{NMR}(300 \mathrm{MHz}, \mathrm{CHLOROFORM}-d) \delta=7.28-7.49(\mathrm{~m}, 10 \mathrm{H}), 3.89(\mathrm{~s}, 2 \mathrm{H}) \mathrm{ppm}$.

${ }^{13} \mathrm{C}$ NMR $(75 \mathrm{MHz}, \mathrm{CHLOROFORM}-d) \delta=137.1,128.6,128.3,125.5,62.8 \mathrm{ppm}$.

${ }^{1} \mathrm{H}$ - and ${ }^{13} \mathrm{C}$ NMR data were consistent with those previously reported. ${ }^{24}$

\section{2-Cyclohexyl-3-octyloxiran (9c)}

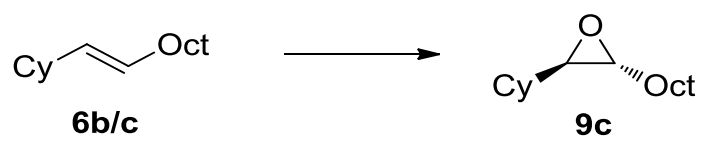

According to $\mathbf{G P 2}^{(*)}$ alkene $6 \mathrm{~b} / \mathrm{c}(140 \mathrm{mg}, 0.63 \mathrm{mmol})$ was transformed into epoxide $9 \mathrm{c}(112 \mathrm{mg}$, $0.47 \mathrm{mmol}, 75 \%)$, isolated as a colorless oil after column chromatography $\left(\mathrm{SiO}_{2}\right.$, CyHex/EtOAc 7:3).

$\mathbf{R}_{\mathbf{f}}=0.74$ (Cyhex/EtOAc, 7:3).

${ }^{1} \mathrm{H}-\mathrm{NMR}(300 \mathrm{MHz}, \mathrm{CHLOROFORM}-d): \delta=2.68-2.73(\mathrm{~m}, 1 \mathrm{H}), 2.42-2.47(\mathrm{dd}, \mathrm{J}=8.8,2.2 \mathrm{~Hz}, 1 \mathrm{H})$, $1.80-1.90(\mathrm{~m}, 1 \mathrm{H}), 1.00-1.69(\mathrm{~m}, 24 \mathrm{H}), 0.88(\mathrm{t}, J=6.9 \mathrm{~Hz}, 3 \mathrm{H}) \mathrm{ppm}$.

${ }^{13} \mathrm{C}-\mathrm{NMR}\left(75 \mathrm{MHZ}, \mathrm{CDCl}_{3}\right): \delta=63.3,57.7,40.2,32.2,31.8,29.8,29.5,29.4,29.2,29.1,26.3,26.1$, 25.7, 25.6, 22.6, $14.1 \mathrm{ppm}$.

IR: $\tilde{v}=2925(\mathrm{~s}), 2853(\mathrm{~m}), 2360(\mathrm{~m}), 2339(\mathrm{~m}), 1652(\mathrm{w}), 1559(\mathrm{w}), 1539(\mathrm{w}), 1456(\mathrm{w}), 668(\mathrm{~s}), 625$ (w), $619(\mathrm{w}) \mathrm{cm}^{-1}$.

MS m/z $\left(\mathrm{ESI}^{+-}\right)$: Compound was not detected by ESI. Identity was confirmed by comparison to data reported for 2-cyclohexyl-3-hexyloxiran. ${ }^{25}$

${ }^{(*)}$ Comment: In divergence from GP2, the product was isolated after stirring for only $3 \mathrm{~h}$.

\footnotetext{
${ }^{24}$ G. Anilkumar, S. Bhor, M. K. Tse, M. Klawonn, B. Bitterlich, M. Beller, Tetrahedron-Asymmetry 2005, 16, 3536-3561.

${ }^{25}$ T. Satoh, Y. Kaneko, K. Yamakawa, Bull. Chem. Soc. Jpn. 1986, 59, 2463-2470.
} 


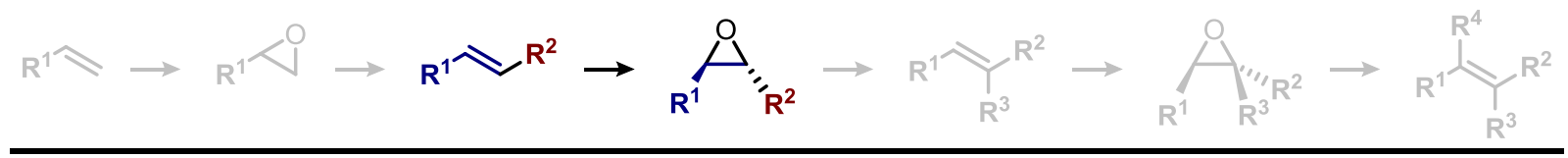

2-Cyclohexyl-3-(2-methyl-2-propanyl) oxiran (9d)

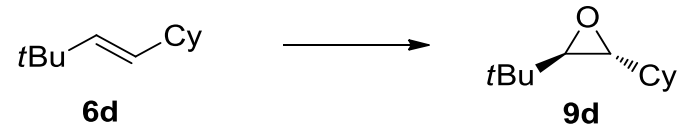

According to $\mathrm{GP2}^{(*)}$ alkene $6 \mathrm{~d}$ (104 $\left.\mathrm{mg}, 1.04 \mathrm{mmol}\right)$ was transformed into epoxide $9 \mathrm{~d}$ (84 $\mathrm{mg}, 0.46$ $\mathrm{mmol}, 44 \%)$, isolated as a colorless oil after column chromatography $\left(\mathrm{SiO}_{2}\right.$, CyHex/EtOAc 7:3).

$\mathbf{R}_{\mathbf{f}}=0.70($ Cyhex/EtOAc, 7:3).

${ }^{1} \mathrm{H}-\mathrm{NMR}\left(300 \mathrm{MHz}, \mathrm{CDCl}_{3}\right): \delta=2.56(\mathrm{dd}, \mathrm{J}=6.6,2.5 \mathrm{~Hz}, 1 \mathrm{H}), 2.47-2.53(\mathrm{~m}, 1 \mathrm{H}), 1.82-1.95(\mathrm{~m}$, $1 \mathrm{H}), 1.56$ - $1.80(\mathrm{~m}, 4 \mathrm{H}), 1.01-1.31(\mathrm{~m}, 6 \mathrm{H}), 0.91$ (s, $9 \mathrm{H}) \mathrm{ppm}$.

${ }^{13} \mathrm{C}-\mathrm{NMR}\left(75 \mathrm{MHZ}, \mathrm{CDCl}_{3}\right): \delta=66.0,59.9,40.4,30.5,29.9,29.1,26.3,25.8,25.7,25.5 \mathrm{ppm}$.

IR: $\tilde{\mathrm{v}}=2360(\mathrm{~s}), 2341(\mathrm{~s}), 1653(\mathrm{w}), 668(\mathrm{~s}) \mathrm{cm}^{-1}$.

MS m/z (ESI $\left.{ }^{+-}\right)$: Compound was not detected by ESI. Identity was confirmed by comparison to other compounds of this series.

${ }^{(*)}$ Comment: In divergence from GP2, the product was isolated after stirring for only $3 \mathrm{~h}$.

2-0ctyl-3-(2-methyl-2-propanyl) oxiran (9e)
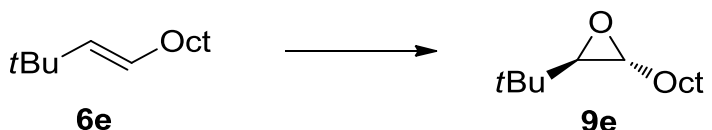

$9 e$

According to $\mathrm{GP2}^{(*)}$ alkene $6 \mathrm{e}(15 \mathrm{mg}, 0.077 \mathrm{mmol})$ was transformed into epoxide $9 \mathrm{e}$ (12 $\mathrm{mg}, 0.031$ $\mathrm{mmol}, 40 \%)$, isolated as a colorless oil after column chromatography $\left(\mathrm{SiO}_{2}, \mathrm{CyHex} / \mathrm{EtOAc} \mathrm{7:3)}\right.$. Yield corrected for grease impurity.

$\mathbf{R}_{\mathbf{f}}=0.80($ Cyhex/EtOAc, $7: 3)$.

${ }^{1} \mathrm{H}-\mathrm{NMR}\left(300 \mathrm{MHz}, \mathrm{CDCl}_{3}\right): \delta=2.74-2.82(\mathrm{~m}, 1 \mathrm{H}), 2.46(\mathrm{~d}, \mathrm{~J}=2.49 \mathrm{~Hz}, 1 \mathrm{H}), 1.35-1.65(\mathrm{~m}, 14 \mathrm{H})$, 0.88-0.91 (m, $12 \mathrm{H}) \mathrm{ppm}$.

${ }^{13} \mathrm{C}-\mathrm{NMR}\left(75 \mathrm{MHZ}, \mathrm{CDCl}_{3}\right): \delta=67.0,55.5,32.3,31.8,30.7,29.7,29.4,29.2,26.2,25.9,22.6,14.1$ ppm.

IR: $\tilde{v}=3744(w), 2923(s), 2854(m), 2360(m), 1700(w), 1652(w), 668(s) \mathrm{cm}^{-1}$.

MS m/z $\left(\mathrm{ESI}^{+-}\right)$: Compound was not detected by ESI. Identity was confirmed by comparison to data reported for 2-Propyl-3-(2-methyl-2-propanyl) oxiran ${ }^{26}$

${ }^{(\star)}$ Comment: In divergence from GP2, the product was isolated after stirring for only $3 \mathrm{~h}$.

${ }^{26}$ A. K. Yudin, J. P. Chiang, H. Adolfsson, C. Copéret, J. Org. Chem. 2001, 66, 4713-4718. 


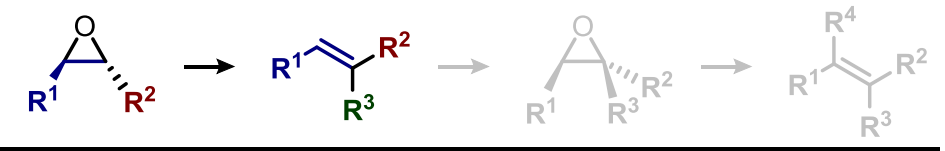

Synthesis of Trisubstituted Alkenes from trans-Epoxides

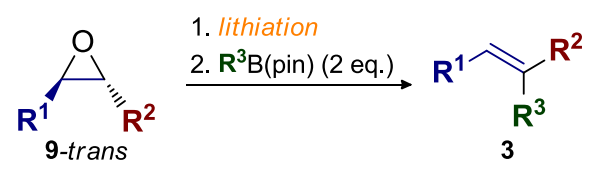

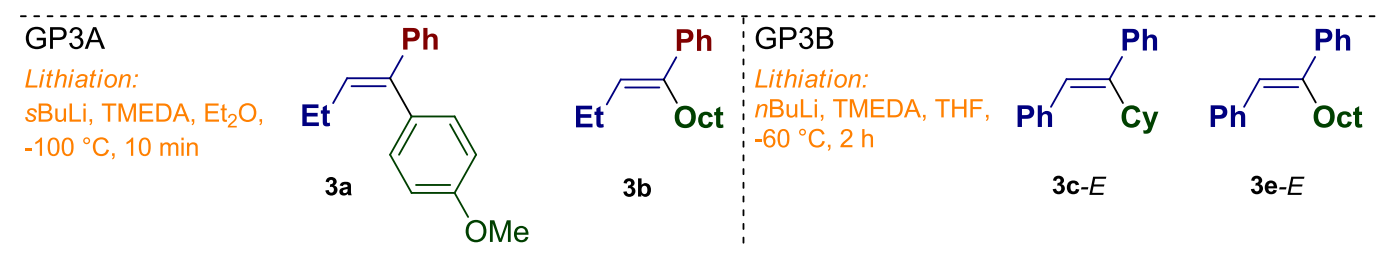

\section{General Procedure Optimized for reaction of 9a (GP3A)}

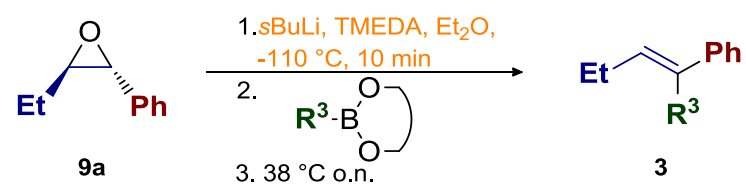

At $-110^{\circ} \mathrm{C} s \mathrm{BuLi}$ in hexanes (1.2 equiv.) was added dropwise to a solution of epoxide 9a and TMEDA (3 equiv.) in dry $\mathrm{Et}_{2} \mathrm{O}(1.5 \mathrm{~mL} / \mathrm{mmol}$ of $9 \mathrm{a})$. After stirring for $10 \mathrm{~min}$ at the same temperature, a solution of appropriate boronic ester in $\mathrm{Et}_{2} \mathrm{O}(2.2$ equiv., $0.34 \mathrm{M})$ was added and stirring was continued for $2 \mathrm{~h}$ at $-110^{\circ} \mathrm{C}$. The reaction mixture was allowed to warm up to room temperature for $0.5 \mathrm{~h}$ and heated to $38^{\circ} \mathrm{C}$ overnight. The solvent was removed in vacuo and the residue was purified by column chromatography $\left(\mathrm{Al}_{2} \mathrm{O}_{3}, \mathrm{CyHex}\right)$.

(Z)-1-Methoxy-4-(1-phenylbut-1-en-1-yl)benzen (3a)<smiles></smiles>

$9 a$<smiles>C/C=C(\c1ccccc1)c1ccc(OC)cc1</smiles>

3a

According to GP3A epoxide 9a (154 mg. $1.04 \mathrm{mmol}$ ) was reacted with $p$-methoxyphenyl neopentyl boronic ester to yield $\mathbf{3 a}$ (156 mg, $0.65 \mathrm{mmol}, 63 \%)$.

$\mathbf{R}_{f}=0.60($ CyHex/EtOAc, 19:1).

${ }^{1} \mathrm{H}$-NMR (300 MHz, CHLOROFORM- $d$ ) $\delta=7.29-7.50(\mathrm{~m}, 5 \mathrm{H}), 7.17-7.29(\mathrm{~m}, 2 \mathrm{H}), 6.95-7.10(\mathrm{~m}, 2$ H), 6.15 (t, J=7.3 Hz, 1 H), 3.97 (s, 3 H), 2.27 (quin, $J=7.5 \mathrm{~Hz}, 2 \mathrm{H}$ ), $1.17 \mathrm{ppm}(\mathrm{t}, J=7.5 \mathrm{~Hz}, 3 \mathrm{H}$ ) ppm.

${ }^{13} \mathrm{C}$ NMR $(75 \mathrm{MHz}, \mathrm{CHLOROFORM}-d) \delta=158.5,143.2,140.5,132.6,131.5,131.0,128.0,127.3$, $126.7,113.5,55.2,23.2,14.5 \mathrm{ppm}$.

${ }^{1} \mathrm{H}$ - and ${ }^{13} \mathrm{C}$ NMR data were consistent with those previously reported. ${ }^{27}$ 


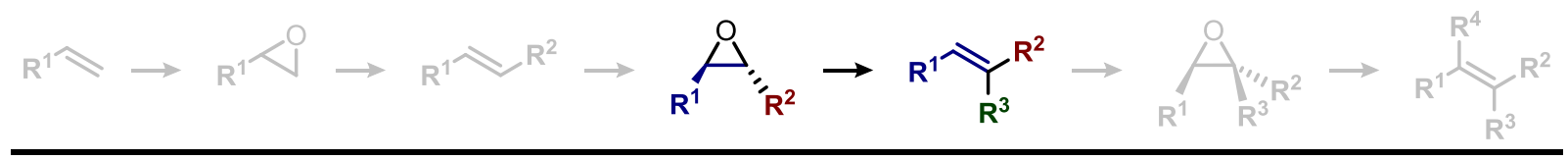

(E)-4-Phenyl-3-dodecene (3b)<smiles>CCOC(=O)C=C(OCC)c1ccccc1</smiles>

According to GP3A epoxide 9a (52 mg. $0.35 \mathrm{mmol}$ ) was reacted with octyl pinacol boronic ester to yield $3 \mathbf{b}$ (56 mg, $0.23 \mathrm{mmol}, 65 \%$ ). When the reaction was conducted with octyl neopentyl boronic ester $\mathbf{3 b}$ was obtained in $53 \%$ yield.

$\mathbf{R}_{f}=0.71$ (CyHex/EtOAc, 19:1).

${ }^{1}$ H-NMR (300 MHz, CHLOROFORM- $d$ ) $\delta=7.14-7.44$ (m, $5 \mathrm{H}$ ), 5.66 (t, $\left.J=7.2 \mathrm{~Hz}, 1 \mathrm{H}\right), 2.42$ - 2.60 (m, $2 \mathrm{H}$ ), 2.24 (quin, J=7.4 Hz, $2 \mathrm{H}$ ), $1.18-1.46(\mathrm{~m}, 12 \mathrm{H}), 1.09$ (t, J=7.5 Hz, $3 \mathrm{H}), 0.73-0.96(\mathrm{~m}, 3 \mathrm{H})$ ppm.

${ }^{13}$ C-NMR (75 MHZ, CHLOROFORM- $d$ ) $\delta=143.5,139.7,130.6,128.1,126.3,126.3,31.9,29.7,29.6$, $29.4,29.3,28.8,22.6,21.9,14.4,14.1 \mathrm{ppm}$.

${ }^{1} \mathrm{H}$ - and ${ }^{13} \mathrm{C} N M R$ data were consistent with those previously reported for (E)-4-Phenyl-3-octene. ${ }^{28}$ Identity was further confirmed after subsequent epoxidation (v.i.).

\section{General Procedure Optimized for reaction of 9b-trans (GP3B)}<smiles></smiles>

9b-trans<smiles>[R3]B1OCCOB(CC)O1</smiles>

3. $60^{\circ} \mathrm{C}$ o.n.<smiles>[R]/C(=C\c1ccccc1)c1ccccc1</smiles>

3

At $-60{ }^{\circ} \mathrm{C} n \mathrm{BuLi}$ in hexanes (1.5 equiv.) was added dropwise to a solution of epoxide $\mathbf{9 b}$-trans and TMEDA ( 3 equiv.) in dry THF $(6.5-7.8 \mathrm{~mL} / \mathrm{mmol}$ of $9 \mathbf{b}$-trans). After stiring for $2 \mathrm{~h}$ at the same temperature, a solution of appropriate boronic ester in THF (2 equiv., $0.61-1.0 \mathrm{M}$ ) was added and stirring was continued for $2 \mathrm{~h}$ at $-60{ }^{\circ} \mathrm{C}$. The reaction mixture was allowed to warm up to room temperature for $0.5 \mathrm{~h}$ and heated to $60^{\circ} \mathrm{C}$ overnight. The reaction mixture was transferred with a small amount of $\mathrm{Et}_{2} \mathrm{O}$ into a separation funnel and extracted with aqueous $\mathrm{NaOH}(1 \mathrm{M}, 3 \mathrm{x})$. The aqueous layers were re-extracted with $\mathrm{Et}_{2} \mathrm{O}(2 \mathrm{x})$ and the combined organic layers were dried over $\mathrm{Na}_{2} \mathrm{SO}_{4}$, concentrated in vacuo and purified by chromatography.

\footnotetext{
${ }^{28}$ J. Gerard, L. Hevesi, Tetrahedron 2001, 57, 9109-9121.
} 


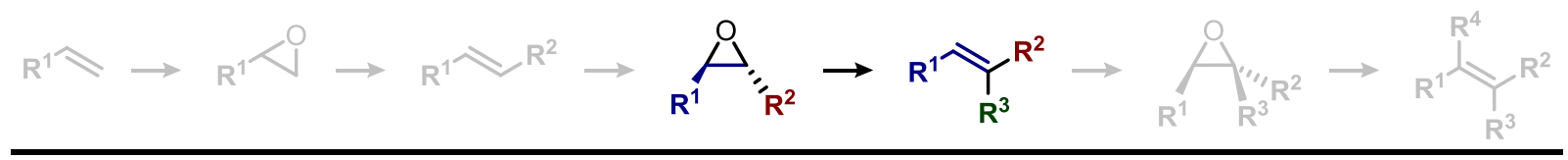

(E)-(1-Cyclohexylethen-1,2-diyl)dibenzen (3c- $E$ )

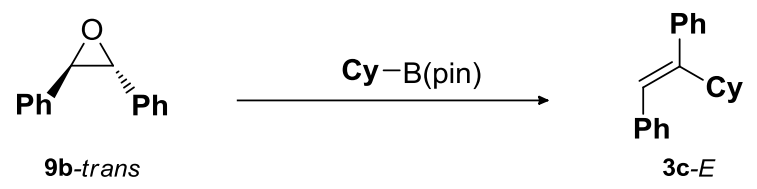

According to GP3B epoxide $9 \mathrm{~b}$-trans $(104 \mathrm{mg}, 0.53 \mathrm{mmol})$ was reacted with cyclohexyl pinacol boronic ester to yield $3 \mathrm{c}-E$ (60 mg, $0.23 \mathrm{mmol}, 44 \%$, de 95\%), as a colorless oil after chromatography $\left(\mathrm{SiO}_{2}, \mathrm{CyHex}\right)$.

$\mathbf{R}_{f}=0.58($ CyHex/EtOAc, 19:1).

${ }^{1} \mathrm{H}$-NMR (300 MHz, CHLOROFORM- $\left.d\right) \delta=7.07-7.48(\mathrm{~m}, 10 \mathrm{H}), 6.31(\mathrm{~s}, 1 \mathrm{H}), 2.79-3.05(\mathrm{~m}, 1 \mathrm{H})$, $0.92-1.85 \mathrm{ppm}(\mathrm{m}, 10 \mathrm{H}) \mathrm{ppm}$.

${ }^{13} \mathrm{C}$ NMR $(75 \mathrm{MHz}$, CHLOROFORM- $d) \delta=149.4,143.3,137.9,128.9,128.8,128.4,128.2,127.5$, $126.5,126.4,40.4,32.1,26.3,25.9 \mathrm{ppm}$.

${ }^{1} \mathrm{H}$ - and ${ }^{13} \mathrm{C} N \mathrm{NM}$ data for the Z-isomer were previously reported and examination of the sprectra published by Zhang et al. revealed contamination with the E-isomer (3c-E). The de for our reaction was determined through integration of the olefinic signals at 6.31 (s, 1H, E-isomer) ppm and 6.38 (s, $1 \mathrm{H}, \mathrm{Z}$-isomer) ppm. ${ }^{29}$ The reaction was also conducted using GP1A and GP3A delivering $3 \mathrm{c}$ in $29 \%$ and $9 \%$ yield, respectively.

(E)-Hex-1-en-1,2-diyldibenzen (3d-E)

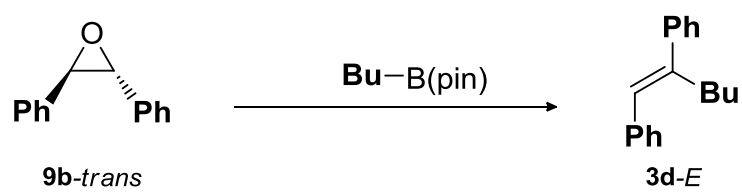

According to GP3B epoxide $9 \mathrm{~b}$-trans $(300 \mathrm{mg} .1 .53 \mathrm{mmol}$ ) was reacted with butyl pinacol boronic ester to yield $3 \mathbf{d}-E(111 \mathrm{mg}, 0.47 \mathrm{mmol}, 31 \%$, de $94 \%)$ as a colorless oil after chromatography $\left(\mathrm{SiO}_{2}\right.$, CyHex).

$\mathbf{R}_{f}=0.52($ CyHex/EtOAc, 19:1).

${ }^{1} \mathrm{H}$-NMR (300 MHz, CHLOROFORM- $\left.d\right) \delta=7.20-7.51(\mathrm{~m}, 10 \mathrm{H}), 6.70(\mathrm{~s}, 1 \mathrm{H}), 2.64-2.76(\mathrm{~m}, 2 \mathrm{H})$, 1.27 - $1.46(\mathrm{~m}, 4 \mathrm{H}), 0.81-0.88(\mathrm{~m}, 3 \mathrm{H}) \mathrm{ppm}$.

${ }^{13}$ C NMR (75 MHz, CHLOROFORM- $\left.d\right) \delta=143.4,143.2,138.4,128.8,128.6,128.3,128.2,128.1$, $127.1,126.6,126.5,125.5,30.9,30.0,22.8,13.9 \mathrm{ppm}$.

${ }^{1} \mathrm{H}$ - and ${ }^{13} \mathrm{C}$ NMR data were consistent with those previously reported. ${ }^{30}$ The de was determined through integration of olefinic signals at 6.70 (s, $1 \mathrm{H}$, E-isomer) ppm and 6.44 (s, $1 \mathrm{H}, \mathrm{Z}$-isomer) ppm. ${ }^{31}$

\footnotetext{
${ }^{29}$ Q.-Q. Wang, Z.-X. Wang, X.-Y. Zhang, X.-S. Fan, Asian J. Org. Chem. 2017, 6, 1445-1450.

${ }^{30}$ F. Xue, J. Zhao, T. S. A. Hor, Chem. Commun. 2013, 49, 10121.

${ }^{31}$ E/Z Relationship according to: D. M. Hodgson, M. J. Fleming, S. J. Stanway, J. Org. Chem. 2007, 72, 4763-4773.
} 


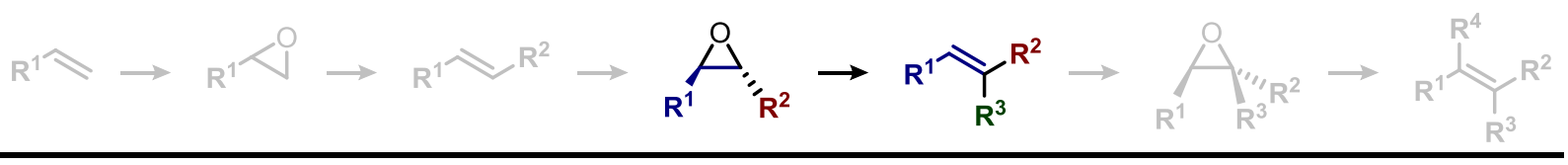

Synthesis of Trisubstituted Alkenes from cis-Stilbene Oxide - General

Procedure (GP3C)

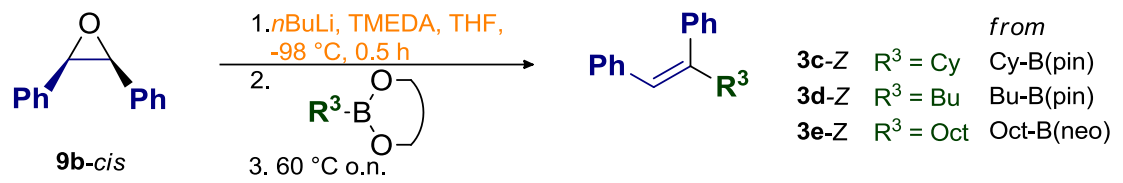

At $-98{ }^{\circ} \mathrm{C} n \mathrm{BuLi}$ in hexanes (1.5 equiv.) was added dropwise to a solution of epoxide $\mathbf{9 b}$-cis and TMEDA (1.5 equiv.) in dry THF ( $8 \mathrm{~mL} / \mathrm{mmol}$ of $9 \mathrm{~b}$-cis). After stirring for $0.5 \mathrm{~h}$ at the same temperature, a solution of appropriate boronic ester in THF $(2.0$ equiv., $0.50 \mathrm{M})$ was added and stirring was continued for $10 \mathrm{~min}$ at $-98^{\circ} \mathrm{C}$. The reaction mixture was allowed to warm up to room temperature for $0.5 \mathrm{~h}$ and heated to $60^{\circ} \mathrm{C}$ overnight. The reaction mixture was transferred with a small amount of $\mathrm{Et}_{2} \mathrm{O}$ into a separation funnel and extracted with aqueous $\mathrm{NaOH}(1 \mathrm{M}, 3 \mathrm{x})$. The aqueous layers were reextracted with $\mathrm{Et}_{2} \mathrm{O}(2 \mathrm{x})$ and the combined organic layers were dried over $\mathrm{Na}_{2} \mathrm{SO}_{4}$, concentrated in vacuo and purified by chromatography over $\mathrm{Al}_{2} \mathrm{O}_{3}$.

(Z)-(1-Cyclohexylethen-1,2-diyl)dibenzen (3c-Z)

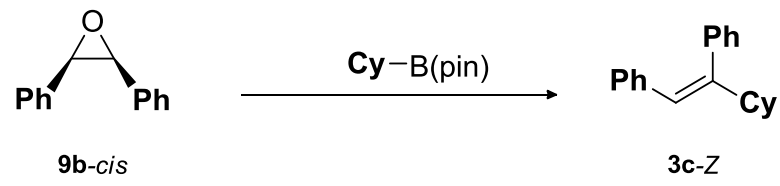

According to GP3C epoxide $9 \mathrm{~b}$-cis $(49 \mathrm{mg}, 0.25 \mathrm{mmol}$ ) was reacted with cyclohexyl pinacol boronic ester to yield $3 \mathbf{c}-Z$ (58 $\mathrm{mg}, 0.22 \mathrm{mmol}, 88 \%)$, as a colorless oil after chromatography $\left(\mathbf{A l}_{2} \mathbf{O}_{3}\right.$, CyHex/EtOAc, 20:1).

$\mathbf{R}_{f}=0.76\left(\mathbf{A l}_{2} \mathbf{O}_{3}\right.$, CyHex/EtOAc, 20:1).

${ }^{1}$ H-NMR (300 MHz, CHLOROFORM- $d$ ) $\delta=7.20-7.36(\mathrm{~m}, 3 \mathrm{H}), 6.92-7.18(\mathrm{~m}, 5 \mathrm{H}), 6.71-6.91(\mathrm{~m}, 2$ $\mathrm{H}), 6.39(\mathrm{~s}, 1 \mathrm{H}), 2.19-2.44(\mathrm{~m}, 1 \mathrm{H}), 1.54-1.96(\mathrm{~m}, 5 \mathrm{H}), 1.03-1.40(\mathrm{~m}, 5 \mathrm{H}) \mathrm{ppm}$.

${ }^{13} \mathrm{C}$ NMR $(75 \mathrm{MHz}$, CHLOROFORM- $d) \delta=148.9,141.6,137.7,129.0,128.9,128.3,127.7,126.6$, $125.9,124.5,47.7,32.3,26.8,26.3 \mathrm{ppm}$.

${ }^{1} \mathrm{H}$ - and ${ }^{13} \mathrm{C}$ NMR data were consistent with those previously reported. ${ }^{32}$.

${ }^{32}$ Q.-Q. Wang, Z.-X. Wang, X.-Y. Zhang, X.-S. Fan, Asian J. Org. Chem. 2017, 6, 1445-1450. 


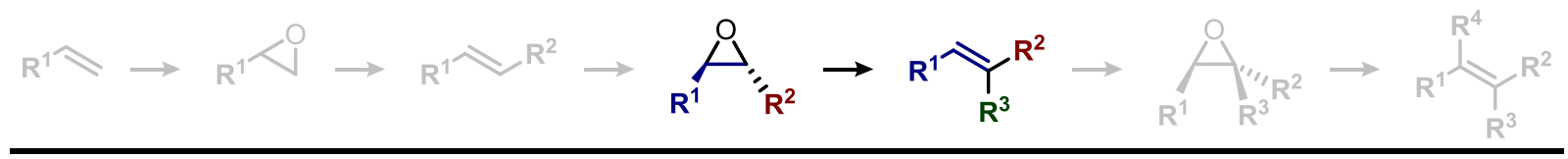

(Z)-Hex-1-en-1,2-diyldibenzen (3d-Z)

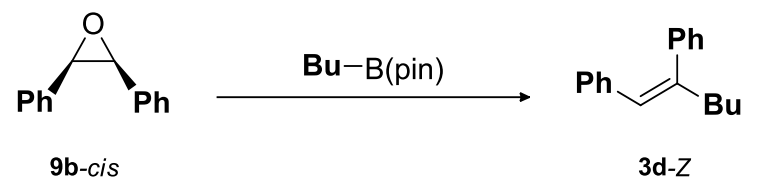

According to GP3C epoxide $9 \mathrm{~b}$-cis $(49 \mathrm{mg} .0 .25 \mathrm{mmol}$ ) was reacted with butyl pinacol boronic ester to yield $\mathbf{3 d}-Z$ (56 mg, $0.24 \mathrm{mmol}, 95 \%)$ as a colorless oil after chromatography $\left(\mathbf{A l}_{2} \mathbf{O}_{3}\right.$, CyHex).

$\mathbf{R}_{\boldsymbol{f}}=0.74\left(\mathbf{A l}_{2} \mathbf{O}_{3}\right.$, CyHex/EtOAc, 20:1).

${ }^{1}$ H-NMR (300 MHz, CHLOROFORM- $d$ ) $\delta=7.19-7.39(\mathrm{~m}, 3 \mathrm{H}), 7.10-7.18(\mathrm{~m}, 2 \mathrm{H}), 6.97-7.11(\mathrm{~m}, 3$ $\mathrm{H}), 6.81-6.96(\mathrm{~m}, 2 \mathrm{H}), 6.42(\mathrm{~s}, 1 \mathrm{H}), 2.48(\mathrm{td}, \mathrm{J}=7.3,1.3 \mathrm{~Hz}, 2 \mathrm{H}), 1.16-1.46(\mathrm{~m}, 4 \mathrm{H}), 0.89(\mathrm{t}, \mathrm{J}=7.2$ $\mathrm{Hz}, 2 \mathrm{H}) \mathrm{ppm}$.

${ }^{13} \mathrm{C}$ NMR $(75 \mathrm{MHz}$, CHLOROFORM- $d) \delta=143.6,141.5,137.6,129.0,128.5,128.4,127.8,126.8$, $126.1,126.0,40.4,30.1,22.3,13.9 \mathrm{ppm}$.

${ }^{1} \mathrm{H}$ - and ${ }^{13} \mathrm{C}$ NMR data were consistent with those previously reported. ${ }^{33}$

(Z)-Dec-1-en-1,2-diyldibenzen $(3 e-Z)$

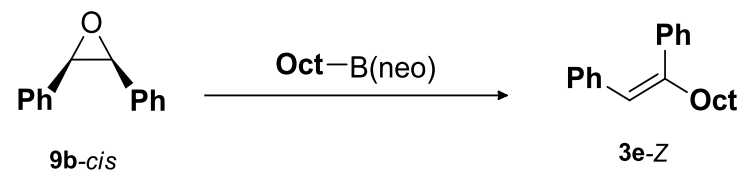

According to GP3C epoxide $9 \mathrm{~b}$-cis (50 mg. $0.25 \mathrm{mmol}$ ) was reacted with octy neopentyl boronic ester to yield $3 \mathbf{e}-Z$ (57 mg, $0.19 \mathrm{mmol}, 78 \%)$ as a colorless oil after chromatography $\left(\mathbf{A l}_{2} \mathbf{O}_{3}\right.$, CyHex/EtOAc, 20:1).

$\mathbf{R}_{\boldsymbol{f}}=0.80\left(\mathbf{A l}_{2} \mathbf{O}_{3}\right.$, CyHex/EtOAc, 20:1).

${ }^{1}$ H-NMR (300 MHz, CHLOROFORM- $d$ ) $\delta=7.22-7.36(\mathrm{~m}, 3 \mathrm{H}), 7.00-7.22(\mathrm{~m}, 5 \mathrm{H}), 6.86-6.98(\mathrm{~m}, 2$ $\mathrm{H}), 6.44(\mathrm{~s}, 1 \mathrm{H}), 2.27$ - $2.66(\mathrm{~m}, 2 \mathrm{H}), 1.06-1.49(\mathrm{~m}, 12 \mathrm{H}), 0.73-0.98(\mathrm{~m}, 3 \mathrm{H}) \mathrm{ppm}$.

${ }^{13} \mathrm{C}$ NMR $(75 \mathrm{MHz}$, CHLOROFORM- $d) \delta=143.6,141.5,137.6,129.0,128.5,128.4,127.8,126.8$, $126.1,126.0,40.7,31.9,29.4,29.3,29.2,27.9,22.6,14.1 \mathrm{ppm}$.

${ }^{1} \mathrm{H}$ - and ${ }^{13} \mathrm{C}$ NMR data were consistent with those previously reported. ${ }^{34}$

\footnotetext{
${ }^{33}$ B. C. Chary, S. Kim, D. Shin, P. H. Lee, Chem. Comm. 2011, 47, 7851.

${ }^{34}$ G. Liu, L. Kong, J. Shen, G. Zhu, Org. Biomol. Chem. 2014, 12, 2310-2321.
} 


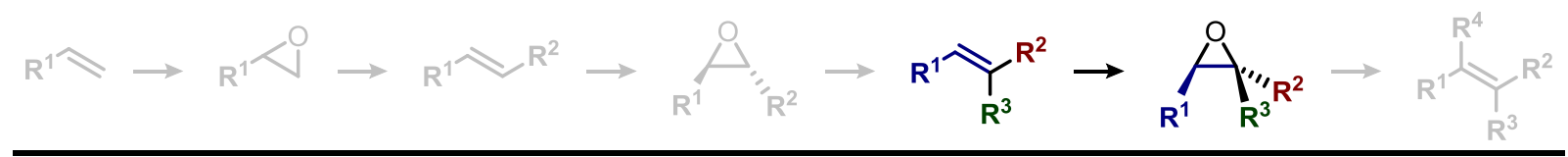

Synthesis of Trisubstituted Epoxides

(2R,3R)-2-Cyclohexyl-2,3-diphenyloxiran (10a-trans)

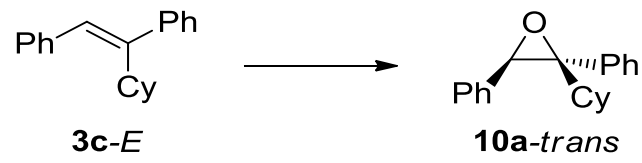

According to GP2 alkene 3c-E (200 mg, $0.76 \mathrm{mmol})$ was transformed into epoxide 10a-trans (200 mg, $0.60 \mathrm{mmol}, 83 \%)$, isolated as a white solid after column chromatography $\left(\mathrm{SiO}_{2}\right.$, CyHex/EtOAc 19:1).

$\mathbf{R}_{f}=0.41$ (CyHex/EtOAc, 19:1).

${ }^{1} \mathrm{H}$-NMR $(600 \mathrm{MHz}, \mathrm{CHLOROFORM}-d) \delta=7.30-7.60(\mathrm{~m}, 10 \mathrm{H}), 4.11(\mathrm{~s}, 1 \mathrm{H}), 1.87-2.01(\mathrm{~m}, 1 \mathrm{H})$, $1.63-1.73(\mathrm{~m}, 1 \mathrm{H}), 1.37-1.52(\mathrm{~m}, 3 \mathrm{H}), 1.31$ (tt, $J=12.1,3.3 \mathrm{~Hz}, 1 \mathrm{H}), 1.13$ (qt, $J=13.0,3.4 \mathrm{~Hz}, 1 \mathrm{H}$ ), 0.97 (qd, J=12.5, $3.5 \mathrm{~Hz}, 1 \mathrm{H}), 0.83-0.93(\mathrm{~m}, 2 \mathrm{H}), 0.73-0.82(\mathrm{~m}, 1 \mathrm{H}) \mathrm{ppm}$

${ }^{13} \mathrm{C}-\mathrm{NMR}(75 \mathrm{MHz}$, CHLOROFORM- $d) \delta=139.2,135.5,130.5,128.2,128.0,127.6,127.5,127.4$, $126.6,70.7,64.7,39.8,28.9,28.2,26.0,25.8 \mathrm{ppm}$.

IR: $\tilde{v}=3086(w), 3064(w), 3032(w), 2929(m), 2855(m), 2360$ (w), 2161 (w, br.), 2024 (w, br.), 1967 (w, br.), $1446(\mathrm{~m}), 882(\mathrm{~m}), 767(\mathrm{~m}), 754(\mathrm{~s}), 693(\mathrm{~s}) \mathrm{cm}^{-1}$.

MS m/z (ESI $): 301.2\left(\mathrm{M}+\mathrm{Na}^{+}, 100 \%\right)$.

HR-MS m/z (ESI $)$ : found: $\left[\mathrm{M}+\mathrm{H}^{+}\right]$279.1744, $\mathrm{C}_{20} \mathrm{H}_{22} \mathrm{OH}$ calculated: 279.1743 .

(2R,3R)-2-Cyclohexyl-2,3-diphenyloxiran (10a-cis)

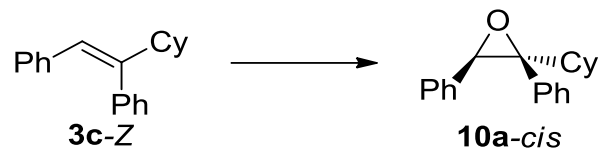

According to GP2 alkene $3 \mathrm{c}-Z$ ( $58 \mathrm{mg}, 0.22 \mathrm{mmol})$ was transformed into epoxide 10a-cis (58 $\mathrm{mg}$, $0.21 \mathrm{mmol}, 94 \%)$, isolated as a white solid after column chromatography $\left(\mathrm{Al}_{2} \mathrm{O}_{3}, \mathrm{CyHex}\right)$.

$\mathbf{R}_{\boldsymbol{f}}=0.67\left(\mathrm{Al}_{2} \mathrm{O}_{3}\right.$, CyHex/EtOAc, 20:1).

${ }^{1} \mathrm{H}$-NMR $(300 \mathrm{MHz}, \mathrm{CHLOROFORM}-d) \delta=7.02-7.20(\mathrm{~m}, 32 \mathrm{H}), 6.87-7.19(\mathrm{~m}, 10 \mathrm{H}), 4.16(\mathrm{~s}, 1 \mathrm{H})$, 1.57 - $2.15(\mathrm{~m}, 6 \mathrm{H}), 0.97-1.36(\mathrm{~m}, 5 \mathrm{H}) \mathrm{ppm}$.

${ }^{13}$ C-NMR (75 MHz, CHLOROFORM- $d$ ) $\delta=136.0,135.6,128.9,127.5,127.2,127.1,126.9,126.4$, $72.3,63.5,46.4,29.3,28.4,26.3,26.1,26.0 \mathrm{ppm}$.

IR: $\tilde{v}=3086$ (w), 3060 (w), 3028 (w), 2927 (w), 2852 (w), 2360 (s), 2339 (s), 1446 (w), 754 (w), $717(w), 698(\mathrm{~m}), 667(w) \mathrm{cm}^{-1}$.

MS (ESI, $70 \mathrm{eV}$ ): found: $\left[\mathrm{M}+\mathrm{H}^{+}\right] 279.1740$, calculated: $\left[\mathrm{M}+\mathrm{H}^{+}\right] 279.1743$. 


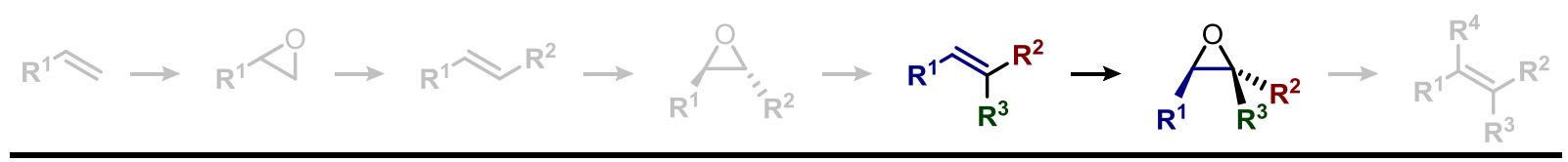

(2R,3R)-2-butyl-2,3-diphenyloxirane (10b-cis)

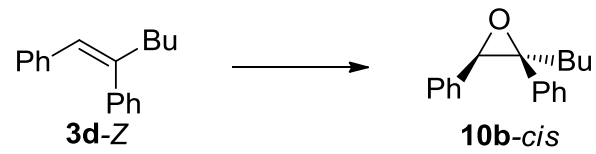

According to GP2 alkene $3 \mathbf{d}-Z$ (46 $\mathrm{mg}, 0.19 \mathrm{mmol}$ ) was transformed into epoxide $10 \mathrm{~b}$-cis (53 $\mathrm{mg}$, $0.16 \mathrm{mmol}, 84 \%$, yield corrected for $12 \%$ CyHex), isolated as a colorless oil after column chromatography $\left(\mathrm{Al}_{2} \mathrm{O}_{3}, \mathrm{CyHex}\right)$.

$\mathbf{R}_{f}=0.60\left(\mathbf{A l}_{2} \mathbf{O}_{3}\right.$, CyHex/EtOAc, 20:1).

${ }^{1}$ H-NMR (300 MHz, CHLOROFORM- $d$ ) $\delta=7.04-7.22(\mathrm{~m}, 8 \mathrm{H}), 6.91-7.06(\mathrm{~m}, 2 \mathrm{H}), 4.15(\mathrm{~s}, 1 \mathrm{H})$, $2.01-2.24(\mathrm{~m}, 1 \mathrm{H}), 1.75-1.95(\mathrm{~m}, 1 \mathrm{H}), 1.13-1.59(\mathrm{~m}, 4 \mathrm{H}), 0.89(\mathrm{t}, \mathrm{J}=6.9 \mathrm{~Hz}, 3 \mathrm{H}) \mathrm{ppm}$.

${ }^{13}$ C-NMR (75 MHz, CHLOROFORM- $d$ ) $\delta=137.1,135.7,127.7,127.6,127.5,127.2,127.0,126.5$, $69.3,64.6,38.7,27.0,22.8,14.0 \mathrm{ppm}$.

IR: $\tilde{v}=3032$ (w), 2954 (w), 2937 (w), 2870 (w), 2856 (w), 2160 (w), 2027 (w, br.), 1977 (w, br.), 1496 (w), $1456(w), 1201(w), 1076(w), 912(w), 885(w), 860(w), 754(m), 698(s) \mathrm{cm}^{-1}$.

MS m/z (ESI $)^{+}: 253.0\left(\mathrm{M}+\mathrm{H}^{+}, 100 \%\right)$.

HR-MS m/z $\left(\mathrm{ESI}^{+}\right)$: found: $\left[\mathrm{M}+\mathrm{H}^{+}\right] 253.160, \mathrm{C}_{18} \mathrm{H}_{20} \mathrm{OH}$ calculated 253.159.

Comment: Using butyl iodide instead of ethyl iodide, the conditions reported below for the synthesis of $10 \mathrm{c}$-cis were also used for preparation of $\mathbf{1 0 b}$-cis in $96 \%$ yield.

(2R,3R)-2-Ethyl-2,3-diphenyloxirane (10c-cis)<smiles>CCOC(C)[Pb]1CCCCC1(C)P</smiles>

To a solution of $9 \mathbf{b}$-cis $(202 \mathrm{mg}, 1.03 \mathrm{mmol})$ in THF $(8 \mathrm{~mL})$ at $-98^{\circ} \mathrm{C}$ was added $s B u L i$ in Hexanes $(0.9 \mathrm{~mL}, 1.35 \mathrm{M}, 1.22 \mathrm{mmol})$ in a drop wise manner. After stirring for $0.5 \mathrm{~h}$ ethyl iodide $(0.1 \mathrm{~mL}$, $1.22 \mathrm{mmol}$ ) was added. The reaction mixture was allowed to reach $\mathrm{rt}$ and stirred overnight after which saturated aq. $\mathrm{NH}_{4} \mathrm{Cl}(4 \mathrm{~mL})$ was added and the mixture was transferred into a separation funnel containing brine $(10 \mathrm{~mL})$. After extraction with EtOAc $(3 \times 10 \mathrm{~mL})$ the combined organic phases were dried over $\mathrm{Na}_{2} \mathrm{SO}_{4}$ and concentrated in vacuo. The residue was purified by chromatography $\left(\mathbf{A l}_{2} \mathrm{O}_{3}\right.$, CyHex/EtOAc 30:1), yielding 10c-cis (216 mg, $0.96 \mathrm{mmol}, 94 \%)$ as a colorless oil. ${ }^{[*]}$

$\mathbf{R}_{f}=0.70\left(\mathrm{Al}_{2} \mathrm{O}_{3}\right.$, CyHex/EtOAc, 10:1).

${ }^{1} \mathrm{H}-\mathrm{NMR}\left(300 \mathrm{MHz}, \mathrm{CDCl}_{3}\right): \delta=7.03-7.41(\mathrm{~m}, 10 \mathrm{H}), 4.27(\mathrm{~s}, 1 \mathrm{H}), 2.28(\mathrm{dq}, \mathrm{J}=14.1,7.5 \mathrm{~Hz}, 1 \mathrm{H}),{ }^{[* *]}$ 2.01 (dq, J=14.3, 7.2 Hz, $1 \mathrm{H}$ ), 1.10 (t, J=7.5 Hz, $3 \mathrm{H}$ ) ppm.

${ }^{13} \mathrm{C}-\mathrm{NMR}\left(75 \mathrm{MHz}, \mathrm{CDCl}_{3}\right): \delta=136.8,135.7,127.8,127.6,127.2,127.0,126.5,69.9,64.4,31.8,9.1$ ppm. 


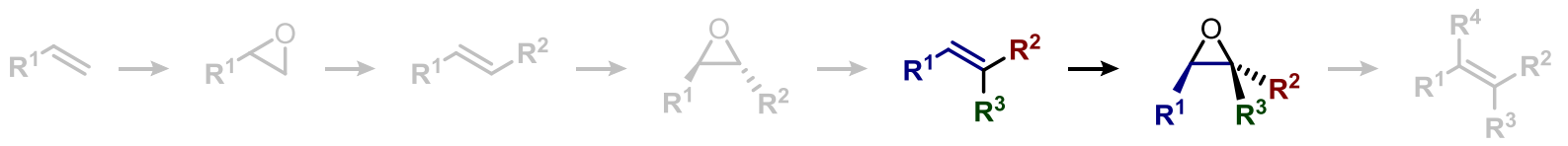

${ }^{1} \mathrm{H}$ - and ${ }^{13} \mathrm{C}$ NMR data were consistent with those previously reported..$^{35}$

\section{Comments:}

${ }^{[*]}$ These conditions were also used to prepare the other diastereomer (10c-trans) from trans-stilbene oxide (9b-trans). This delivered a 7:1 mixture of 10c-trans and the ortho-lithiation product in $57 \%$ yield.

${ }^{[* *]}$ Resolution of this signal in a $300 \mathrm{MHz}$ NMR required application of a Lorenz-Gaussian window function upon Fourier-Transformation.

(2R,3R)-3-Ethyl-2-octyl-2-phenyloxirane (10d)<smiles></smiles>

According to GP2 alkene $3 \mathbf{b}$ (56 $\mathrm{mg}, 0.23 \mathrm{mmol}$ ) was transformed into epoxide $10 \mathrm{~d}$ (42 $\mathrm{mg}$,

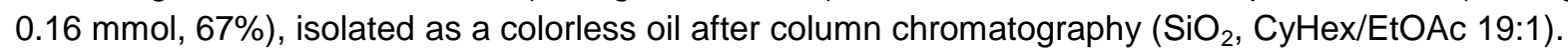

$\mathbf{R}_{\boldsymbol{f}}=0.57$ (CyHex/EtOAc, 9:1).

${ }^{1}$ H-NMR (300 MHz, CHLOROFORM- $d$ ) $\delta=7.12-7.42(\mathrm{~m}, 5 \mathrm{H}), 2.78(\mathrm{t}, \mathrm{J}=6.4 \mathrm{~Hz}, 1 \mathrm{H}), 1.98$ - $2.22(\mathrm{~m}$, $1 \mathrm{H}), 1.59-1.83(\mathrm{~m}, 3 \mathrm{H}), 1.15-1.48(\mathrm{~m}, 12 \mathrm{H}), 1.10(\mathrm{t}, \mathrm{J}=7.5 \mathrm{~Hz}, 3 \mathrm{H}), 0.87$ (t, J=6.6 Hz, $3 \mathrm{H}) \mathrm{ppm}$.

${ }^{13} \mathrm{C}-N M R(75 \mathrm{MHz}$, CHLOROFORM- $d) \delta=141.8,128.2,127.0,125.9,67.7,64.7,31.8,31.1,29.8$, $29.4,29.2,25.1,22.6,22.0,14.1,10.6 \mathrm{ppm}$.

IR: $\tilde{v}=3064(w), 3035(w), 2955(m), 2924(m), 2855(m), 2360(s), 2341(s), 2158(w, b r),. 2026(w$, br.), $1653(\mathrm{~m}), 1559(\mathrm{~m}), 1507(\mathrm{~m}), 1457(\mathrm{~m}), 905(\mathrm{w}), 744(\mathrm{~m}), 698(\mathrm{~s}), 668(\mathrm{~s}) \mathrm{cm}^{-1}$.

MS m/z (ESI $\left.{ }^{+}\right): 283.2\left(\mathrm{M}+\mathrm{Na}^{+}, 100 \%\right)$.

HR-MS m/z (ESI $)$ : found: [M+Na $\left.{ }^{+}\right]$283.2038, $\mathrm{C}_{18} \mathrm{H}_{28} \mathrm{ONa}$ calculated: 283.2032.

Comment: This compound was prepared to confirm structure $\mathbf{3 b}$.

\footnotetext{
${ }^{35}$ S. Oudeyer, E. Léonel, J. P. Paugam, J.-Y. Nédélec, Synthesis 2004, 389-400.
} 


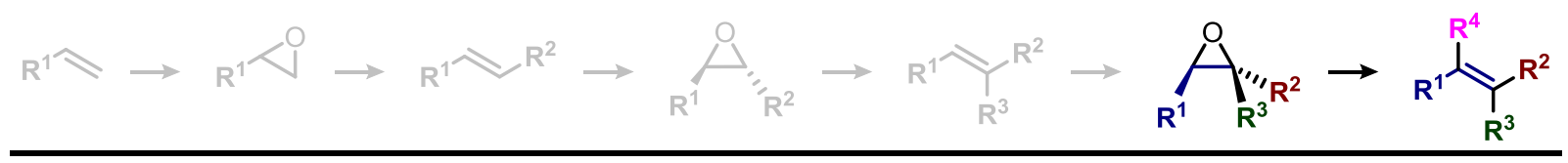

Synthesis of Tetrasubstituted Alkenes - General Procedure (GP4)<smiles>[P][C@]1(P)O[C@@H]1c1ccccc1</smiles>

$10-c i s$

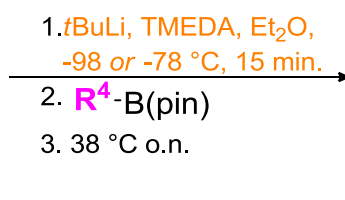<smiles></smiles>

11b $\mathrm{R}^{3}=\mathrm{Bu} \quad \mathrm{R}^{4}=\mathrm{Ph}$

11c $\mathrm{R}^{3}=\mathrm{Bu} \quad \mathrm{R}^{4}=\mathrm{Cy}$

11d $R^{3}=B u \quad R^{4}=$ Oct

11e $\mathrm{R}^{3}=\mathrm{Et} \quad \mathrm{R}^{4}=\mathrm{Ph}$

$11 f \quad R^{3}=$ Et $\quad R^{4}=P M P$

$11 \mathrm{E} E$-Tamoxifen

At $-78{ }^{\circ} \mathrm{C}$ tBuLi in pentane (1.1-1.3 equiv.) was added dropwise to a solution of epoxide 10-cis and TMEDA (6 equiv.) in dry $\mathrm{Et}_{2} \mathrm{O}(9-10 \mathrm{~mL} / \mathrm{mmol}$ of 10 -cis). After stirring for $15 \mathrm{~min}$. at the same temperature, a solution of appropriate boronic ester in $\mathrm{Et}_{2} \mathrm{O}$ (2.0 equiv., 0.40-0.44 $\mathrm{M}$ ) was added. The reaction mixture was allowed to warm up to room temperature for $0.5 \mathrm{~h}$ and heated to $38^{\circ} \mathrm{C}$ overnight. The reaction mixture was transferred with a small amount of $\mathrm{Et}_{2} \mathrm{O}$ into a separation funnel and extracted with aqueous $\mathrm{NaOH}(1 \mathrm{M}, 3 \mathrm{x})$. The aqueous layers were re-extracted with $\mathrm{Et}_{2} \mathrm{O}(2 \mathrm{x})$ and the combined organic layers were dried over $\mathrm{Na}_{2} \mathrm{SO}_{4}$, concentrated in vacuo and purified by chromatography.

Hex-1-ene-1,1,2-triyltribenzene (11b)<smiles>[Pb]C1OC1[Pb]</smiles>

10b-cis

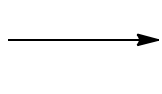

According to GP4 epoxide $10 \mathrm{~b}$-cis ( $50 \mathrm{mg}, 0.20 \mathrm{mmol}$ ) was transformed into alkene 11b (20 $\mathrm{mg}, 0.06$ $\mathrm{mmol}, 32 \%)$ at $-78{ }^{\circ} \mathrm{C}$, isolated as a white solid after column chromatography $\left(\mathbf{A l}_{2} \mathbf{O}_{3}, \mathrm{CyHex}\right)$.

$\mathbf{R}_{\boldsymbol{f}}=0.55\left(\mathrm{SiO}_{2}\right.$, CyHex/EtOAc, 20:1).

${ }^{1}$ H-NMR (300 MHz, CHLOROFORM- $d$ ) $\delta=7.33-7.38(\mathrm{~m}, 2 \mathrm{H}), 7.24-7.31(\mathrm{~m}, 3 \mathrm{H}), 7.10-7.18(\mathrm{~m}, 5$ $\mathrm{H}), 6.97-7.05(\mathrm{~m}, 3 \mathrm{H}), 6.86-6.95(\mathrm{~m}, 2 \mathrm{H}), 2.45(\mathrm{t}, \mathrm{J}=7.5 \mathrm{~Hz}, 2 \mathrm{H}), 1.17-1.37(\mathrm{~m}, 4 \mathrm{H}), 0.79(\mathrm{t}$, $J=7.2 \mathrm{~Hz}, 3 \mathrm{H}) \mathrm{ppm}$.

${ }^{13}$ C-NMR (75 MHz, CHLOROFORM- $\left.d\right) \delta=143.5,143.1,142.5,141.1,139.0,130.7,129.6,129.5$, $128.1,127.8,127.3,126.5,126.1,125.7,35.6,31.1,22.8,13.9 \mathrm{ppm}$.

${ }^{1} \mathrm{H}$ - and ${ }^{13} \mathrm{C}$ NMR data were consistent with those previously reported. ${ }^{36}$

Comment: When deprotonation was attempted at $-98^{\circ} \mathrm{C}$ the product was isolated in $22 \%$ yield.

\footnotetext{
${ }^{36}$ C. Zhou, R. C. Larock, J. Org. Chem. 2005, 70, 3765-3777.
} 


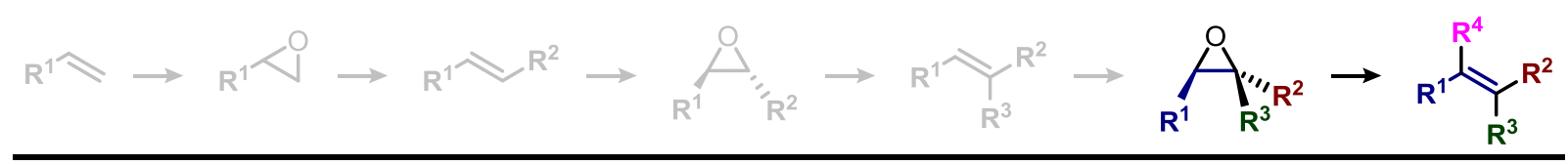

(Z)-(1-Cyclohexylhex-1-ene-1,2-diyl)dibenzene (11c)<smiles>[Pb]C1OC1[PbH3+]</smiles>

$10 \mathrm{~b}-c i s$<smiles>ClC(Br)=C(Cl)c1ccccc1</smiles>

According to GP4 epoxide $10 \mathrm{~b}$-cis $(50 \mathrm{mg}, 0.20 \mathrm{mmol}$ ) was transformed into alkene 11c $(36 \mathrm{mg}$, $0.11 \mathrm{mmol}, 56 \%)$ at $-78{ }^{\circ} \mathrm{C}$, isolated as a colorless oil after column chromatography $\left(\mathrm{Al}_{2} \mathrm{O}_{3}, \mathrm{CyHex}\right)$.

$\mathbf{R}_{f}=0.62($ CyHex/EtOAc, 20:1).

${ }^{1} \mathrm{H}$-NMR (300 MHz, CHLOROFORM- $d$ ) $\delta=6.81-7.08(\mathrm{~m}, 10 \mathrm{H}), 2.81$ (tt, J=11.9, $\left.3.1 \mathrm{~Hz}, 1 \mathrm{H}\right), 2.45-$ $2.63(\mathrm{~m}, 2 \mathrm{H}), 1.56-1.84(\mathrm{~m}, 5 \mathrm{H}), 1.25-1.46(\mathrm{~m}, 5 \mathrm{H}), 0.95-1.22(\mathrm{~m}, 4 \mathrm{H}), 0.91(\mathrm{t}, \mathrm{J}=6.9 \mathrm{~Hz}, 3 \mathrm{H})$ ppm.

${ }^{13}$ C-NMR $(75 \mathrm{MHz}$, CHLOROFORM- $d) \delta=143.9,143.4,141.2,138.1,130.7,129.4,127.1,126.7$, $125.2,125.1,41.3,33.4,32.2,31.0,26.8,25.9,22.7,14.0$ ppm.

IR: $\tilde{v}=3078(w), 3053(w), 3020(w), 2925(m), 2852(w), 2360(w), 2339(w), 1489(w), 1442(w), 771$ (w), $698(\mathrm{~s}) \mathrm{cm}^{-1}$.

HR-MS m/z $\left(\mathrm{ESI}^{+}\right)$: found: [M+Na $]$341.2240, $\mathrm{C}_{24} \mathrm{H}_{30} \mathrm{Na}$ calculated: 341.2240 .

Stereochemical assignment: $\mathrm{A}$ clear nOe signal between the allylic cyclohexyl $\mathrm{CH}(2.81, \mathrm{tt}, \mathrm{J}=11.3,3.3 \mathrm{~Hz})$, and the allylic butyl $\mathrm{CH}_{2}(2.55, \mathrm{~m})$ confirmed formation of the Z-olefin $11 \mathrm{c}$.

Comment: When deprotonation was attempted at $-98{ }^{\circ} \mathrm{C}$ the product was

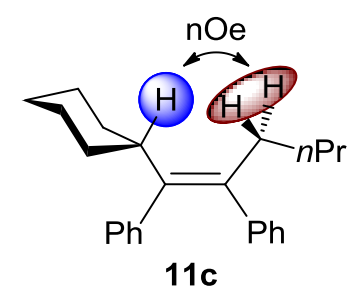
isolated in $28 \%$ yield.

(Z)-Tetradec-5-ene-5,6-diyldibenzene (11d)

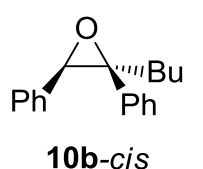

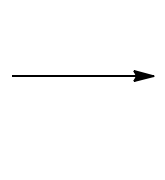<smiles>CCOC(=C(Br)c1ccccc1)c1ccccc1</smiles>

According to GP4 epoxide 10b-cis $(50 \mathrm{mg}, 0.20 \mathrm{mmol}$ ) was transformed into alkene 11d (45 mg, $0.13 \mathrm{mmol}, 64 \%)$ at $-78{ }^{\circ} \mathrm{C}$, isolated as a colorless oil after column chromatography $\left(\mathrm{Al}_{2} \mathrm{O}_{3}, \mathrm{CyHex}\right)$.

$\mathbf{R}_{\boldsymbol{f}}=0.58($ CyHex/EtOAc, 20:1).

1H-NMR (300 MHz, CHLOROFORM-d) $\delta=6.86-7.12(\mathrm{~m}, 10 \mathrm{H}), 2.47-2.60(\mathrm{~m}, 4 \mathrm{H}), 1.16-1.40(\mathrm{~m}$, $16 \mathrm{H}), 0.89$ (t, J=6.6 Hz, $6 \mathrm{H}) \mathrm{ppm}$.

${ }^{13}$ C-NMR $(75 \mathrm{MHz}$, CHLOROFORM- $d) \delta=143.6,138.3,138.3,129.8,127.3,125.3,34.3,34.1,31.9$, $30.7,29.6,29.5,29.3,28.4,22.7,22.6,14.1,14.0 \mathrm{ppm}$.

IR: $\tilde{v}=3078(w), 3057(w), 3020(w), 2924(m), 2856(w), 1441(w), 769(m), 896(s) \mathrm{cm}^{-1}$.

HR-MS m/z (ESI $\left.{ }^{+}\right)$: found: $\left[\mathrm{M}+\mathrm{Na}^{+}\right] 371.2710, \mathrm{C}_{18} \mathrm{H}_{28} \mathrm{ONa}$ calculated: 371.2709 .

Comment: When deprotonation was attempted at $-98^{\circ} \mathrm{C}$ the product was isolated in $36 \%$ yield. As the allylic signals overlapped, no confirmation of the configuration by nOe was possible in this case. 


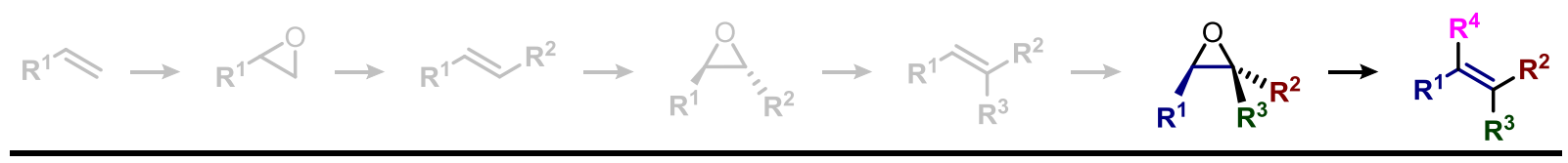

But-1-ene-1,1,2-triyltribenzene (11e)
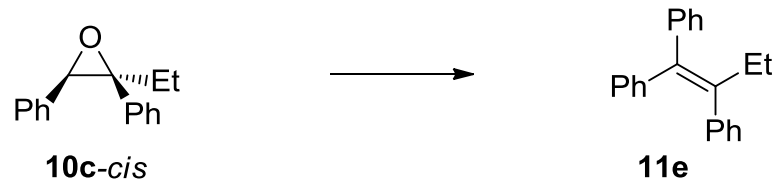

According to GP4 epoxide 10c-cis (50 mg, $0.22 \mathrm{mmol}$ ) was transformed into alkene 11e (26 mg, 0.09 $\mathrm{mmol}, 41 \%)$ at $-78{ }^{\circ} \mathrm{C}$, isolated as a white solid after column chromatography $\left(\mathrm{Al}_{2} \mathrm{O}_{3}, \mathrm{CyHex}\right)$.

$\mathbf{R}_{f}=0.70\left(\mathbf{A l}_{2} \mathrm{O}_{3}\right.$, CyHex/EtOAc, 20:1).

${ }^{1}$ H-NMR (300 MHz, CHLOROFORM- $d$ ) $\delta=7.23-7.39(\mathrm{~m}, 5 \mathrm{H}), 7.07-7.20(\mathrm{~m}, 5 \mathrm{H}), 6.94-7.05(\mathrm{~m}, 3$ H), 6.85 - 6.94 (m, 2 H), 2.49 (q, J=7.5 Hz, 2 H), 0.95 (t, J=7.5 Hz, 3 H) ppm.

${ }^{13} \mathrm{C}-\mathrm{NMR}(75 \mathrm{MHz}$, CHLOROFORM- $d) \delta=143.5,143.0,142.2,142.2,138.8,130.7,129.7,129.4$, $128.1,127.8,127.3,126.6,126.1,125.7,29.0,13.5 \mathrm{ppm}$.

${ }^{1} \mathrm{H}$ - and ${ }^{13} \mathrm{C}$ NMR data were consistent with those previously reported. ${ }^{37}$

Comment: When deprotonation was attempted at $-98^{\circ} \mathrm{C}$ the product was isolated in $35 \%$ yield.

(E)-(1-(4-Methoxyphenyl)but-1-ene-1,2-diyl)dibenzene (11f)<smiles>CC[Pb]1(P)OC1[Pb]</smiles>

10c-cis<smiles>CCC(=C(c1ccccc1)c1ccccc1)c1ccccc1</smiles>

$11 \mathrm{f}$

According to GP4 epoxide 10c-cis (51 $\mathrm{mg}, 0.23 \mathrm{mmol}$ ) was transformed into alkene 11e $(69 \mathrm{mg}$, $0.20 \mathrm{mmol}, 87 \%)$ at $-78^{\circ} \mathrm{C}$, isolated as a white solid after column chromatography $\left(\mathbf{A l}_{2} \mathrm{O}_{3}, \mathrm{CyHex}\right)$.

$\mathbf{R}_{f}=0.57\left(\mathbf{A l}_{2} \mathrm{O}_{3}\right.$, CyHex/EtOAc, 20:1).

${ }^{1}$ H-NMR (300 MHz, CHLOROFORM- $\left.d\right) \delta=6.97-7.21(\mathrm{~m}, 10 \mathrm{H}), 6.83-6.95(\mathrm{~m}, 4 \mathrm{H}), 3.84(\mathrm{~s}, 3 \mathrm{H})$, 2.53 (q, J=7.5 Hz, $2 \mathrm{H}$ ), 0.96 (t, J=7.5 Hz, $3 \mathrm{H}$ ) ppm.

${ }^{13} \mathrm{C}-\mathrm{NMR}(75 \mathrm{MHz}$, CHLOROFORM- $d) \delta=158.3,143.4,142.4,141.9,138.4,136.0,130.8,130.6$, $129.7,127.7,127.3,126.0,125.6,55.2,29.0,13.6 \mathrm{ppm}$.

${ }^{1} \mathrm{H}$ - and ${ }^{13} \mathrm{C}$ NMR data were consistent with those previously reported. ${ }^{38}$

Comment: When deprotonation was attempted at $-98{ }^{\circ} \mathrm{C}$ the product was isolated in $61 \%$ yield. $\left(^{*}\right)$ Sample initially contaminated with $10 \%$ starting material. Yield corrected accordingly.

\footnotetext{
${ }^{37}$ Z. He, S. Kirchberg, R. Fröhlich, A. Studer, Angew. Chem., Int. Ed. 2012, 51, 3699-3702.

${ }^{38}$ B. X. Li, D. N. Le, K. A. Mack, A. McClory, N.-K. Lim, T. Cravillion, S. Savage, C. Han, D. B. Collum, H. Zhang, et al., J. Am. Chem. Soc. 2017, 139, 10777-10783.
} 


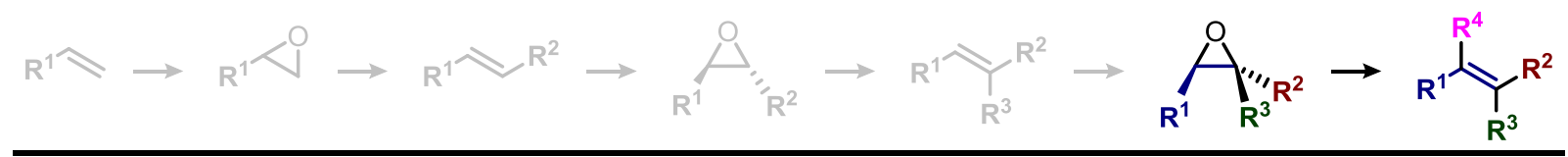

(E)-2-(4-(1,2-diphenylbut-1-en-1-yl)phenoxy)- $N, N$-dimethylethanamine (11g)

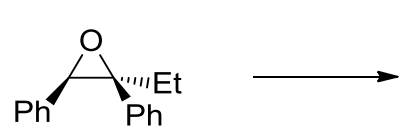

10c-cis<smiles>CCC(=C(c1ccccc1)c1ccc(OCCN(C)C)cc1)c1ccccc1</smiles>

$11 \mathrm{~g}$

According to GP4 epoxide 10c-cis (47 mg, $0.21 \mathrm{mmol}$ ) was transformed into alkene $11 \mathrm{~g}(49 \mathrm{mg}$, $0.13 \mathrm{mmol}, 63 \%)$ at $-78{ }^{\circ} \mathrm{C}$, isolated as a white solid after column chromatography $\left(\mathrm{Al}_{2} \mathrm{O}_{3}, \mathrm{DCM} / \mathrm{MeOH}\right.$ 99:1).

$\mathbf{R}_{f}=0.25\left(\mathrm{Al}_{2} \mathbf{O}_{3}, \mathrm{DCM} / \mathrm{MeOH}, 9: 1\right)$.

${ }^{1}$ H-NMR (300 MHz, CHLOROFORM- $d$ ) $\delta=6.96-7.21(\mathrm{~m}, 10 \mathrm{H}), 6.85-6.94(\mathrm{~m}, 4 \mathrm{H}), 4.12(\mathrm{t}, \mathrm{J}=5.8$ $\mathrm{Hz}, 2 \mathrm{H}$ ), 2.79 (t, J=5.6 Hz, $2 \mathrm{H}$ ), 2.52 (q, J=7.3 Hz, $2 \mathrm{H}$ ), 2.39 (s, $6 \mathrm{H}), 0.95$ (t, J=7.4 Hz, $3 \mathrm{H}$ ) ppm.

${ }^{13}$ C-NMR (75 MHz, CHLOROFORM- $d$ ) $\delta=157.7,143.5,142.6,142.1,138.6,136.3,130.9,130.7$, $129.9,127.9,127.4,126.2,125.8,114.3,65.9,58.4,46.0,29.2,13.7 \mathrm{ppm}$.

${ }^{1} \mathrm{H}$ - and ${ }^{13} \mathrm{C}$ NMR data were consistent with those previously reported. ${ }^{39}$

Comment: The boronic ester employed was not completely soluble in $\mathrm{Et}_{2} \mathrm{O}$ and added as a suspension in $1 \mathrm{~mL}$ dry $\mathrm{Et}_{2} \mathrm{O}$. Therefore the flask and syringe were rinsed with additional $\mathrm{Et}_{2} \mathrm{O}(1 \mathrm{~mL})$.

\section{Optimization Experiments}

The following experiments were carried out in order to optimize GP 4 using a mixture of $\mathbf{1 0 b} / \mathbf{c}$-cis. These experiments indicate that lithiation times of $15-30 \mathrm{~min}$ at $-98{ }^{\circ} \mathrm{C}$ are optimal. While shorter lithiation times led to incomplete conversion, longer lithiation times could very well lead to decomposition of the formed carbenoids.

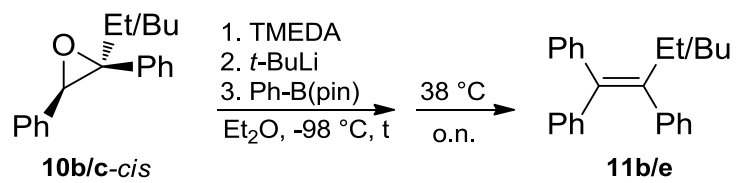

\begin{tabular}{|c|c|c|}
\hline Entry & $\mathbf{t}$ & Yield Alkene \\
\hline 1 & $5 \mathrm{~min}$ & $48 \%$ \\
\hline 2 & $15 \mathrm{~min}$ & $60 \%$ \\
\hline 3 & $30 \mathrm{~min}$ & $62 \%$ \\
\hline 4 & $60 \mathrm{~min}$ & $50 \%$ \\
\hline
\end{tabular}

\footnotetext{
${ }^{39}$ K. Itami, T. Kamei, J. Yoshida, J. Am. Chem. Soc. 2003, 125, 14670-14671.
} 


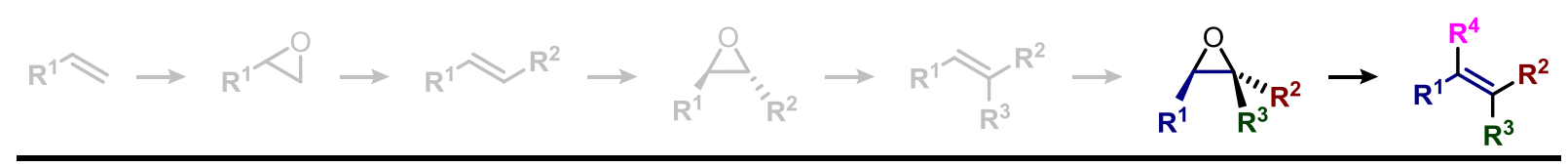

Failed Attempts at Quarternary Alkene Synthesis from 10-trans

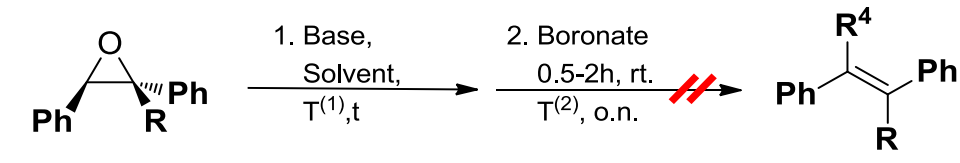

10a-trans $\mathbf{R}=\mathbf{C y}$

11

10c-trans $\mathbf{R}=\mathbf{E t}$

\begin{tabular}{|c|c|c|c|c|c|c|c|c|}
\hline Entry & Base & Solvent & $T^{(1)}$ & $t^{(1)}$ & Boronate & $\mathbf{R}$ & $T^{(2)}$ & Result \\
\hline 1 & LiTMP & THF & $0{ }^{\circ} \mathrm{C}$ & $30 \mathrm{~min}$. & $\begin{array}{l}\text { PMP-B(neo) } \\
\text { (in situ) }\end{array}$ & Cyclohexyl & $60^{\circ} \mathrm{C}$ & $\begin{array}{c}\text { no conversion } \\
\text { of } 10 \mathrm{a} \text {-trans }\end{array}$ \\
\hline 2 & $\begin{array}{c}\text { sBuLi } \\
\text { (TMEDA } \\
3 \text { equiv.) }\end{array}$ & $\mathrm{Et}_{2} \mathrm{O}$ & $-110^{\circ} \mathrm{C}$ & $10 \mathrm{~min}$. & PMP-B(pin) & Cyclohexyl & $38^{\circ} \mathrm{C}$ & $\begin{array}{c}\text { no conversion } \\
\text { of } 10 \text { a-trans }\end{array}$ \\
\hline 3 & $\begin{array}{c}t \text { BuLi } \\
\text { (TMEDA } \\
3 \text { equiv.) }\end{array}$ & $\mathrm{Et}_{2} \mathrm{O}$ & $-110^{\circ} \mathrm{C}$ & $10 \mathrm{~min}$. & PMP-B(neo) & Cyclohexyl & $38^{\circ} \mathrm{C}$ & $\begin{array}{c}\text { no conversion } \\
\text { of } 10 \mathrm{a} \text {-trans }\end{array}$ \\
\hline 4 & $\begin{array}{c}\text { nBuLi } \\
\text { (TMEDA } \\
\text { 3 equiv.) }\end{array}$ & THF & $-60^{\circ} \mathrm{C}$ & $2 \mathrm{~h}$ & PMP-B(neo) & Cyclohexyl & $60^{\circ} \mathrm{C}$ & $\begin{array}{c}\text { no conversion } \\
\text { of } 10 \text { a-trans }\end{array}$ \\
\hline 5 & $\begin{array}{c}\text { sBuLi } \\
\text { (TMEDA } \\
\text { 3 equiv.) }\end{array}$ & PhMe & $-50^{\circ} \mathrm{C}$ & $30 \mathrm{~min}$. & PMP-B(neo) & Cyclohexyl & $100^{\circ} \mathrm{C}$ & $\begin{array}{c}\text { no conversion } \\
\text { of } 10 \text { a-trans }\end{array}$ \\
\hline 6 & $\begin{array}{c}\text { sBuLi } \\
\text { (TMEDA } \\
\text { 3 equiv.) }\end{array}$ & PhMe & $-50^{\circ} \mathrm{C}$ & $2 \mathrm{~h}$ & PMP-B(neo) & Cyclohexyl & $100^{\circ} \mathrm{C}$ & $\begin{array}{c}\text { no conversion } \\
\text { of } 10 \text { a-trans }\end{array}$ \\
\hline 7 & $\begin{array}{c}t \text { BuLi } \\
\text { (TMEDA } \\
6 \text { equiv.) }\end{array}$ & $\mathrm{Et}_{2} \mathrm{O}$ & $-98^{\circ} \mathrm{C}$ & $5 \mathrm{~min}$ & $\mathrm{Ph}-\mathrm{B}($ neo) & Ethyl & $38^{\circ} \mathrm{C}$ & $\begin{array}{c}\text { no conversion } \\
\text { of } 10 \mathrm{c} \text {-trans }\end{array}$ \\
\hline 8 & $\begin{array}{c}t \text { BuLi } \\
\text { (TMEDA } \\
6 \text { equiv.) }\end{array}$ & $\mathrm{Et}_{2} \mathrm{O}$ & $-78^{\circ} \mathrm{C}$ & $2 \mathrm{~h}$ & $\mathrm{Ph}-\mathrm{B}($ neo) & Ethyl & $38^{\circ} \mathrm{C}$ & $\begin{array}{c}\text { no conversion } \\
\text { of } 10 \mathrm{c} \text {-trans }\end{array}$ \\
\hline 9 & $\begin{array}{c}t \text { BuLi } \\
\text { (TMEDA } \\
6 \text { equiv.) }\end{array}$ & $\mathrm{Et}_{2} \mathrm{O}$ & $-50^{\circ} \mathrm{C}$ & $2 \mathrm{~h}$ & $\mathrm{Ph}-\mathrm{B}($ neo) & Ethyl & $38^{\circ} \mathrm{C}$ & $\begin{array}{c}\text { no conversion } \\
\text { of } 10 \text { c-trans }\end{array}$ \\
\hline 10 & $\begin{array}{c}\mathrm{KOt}-\mathrm{Bu} \\
n-\mathrm{BuLi}^{(\mathrm{a})}\end{array}$ & THF & $\begin{array}{c}-78^{\circ} \mathrm{C} \\
\text { to }-48^{\circ} \mathrm{C}\end{array}$ & $2 \mathrm{~h}$ & Ph-B(neo) & Cyclohexyl & $60^{\circ} \mathrm{C}$ & $\begin{array}{l}13 \text { Су } \\
(>95 \%)^{*}\end{array}$ \\
\hline 11 & $\begin{array}{c}\mathrm{KOt}-\mathrm{Bu} \\
n-\mathrm{BuLi}^{(\mathrm{b})}\end{array}$ & THF & $\begin{array}{c}-78{ }^{\circ} \mathrm{C} \\
\text { to }-48^{\circ} \mathrm{C}\end{array}$ & $2 \mathrm{~h}$ & $\mathrm{Ph}-\mathrm{B}($ neo) & Cyclohexyl & $60^{\circ} \mathrm{C}$ & $\begin{array}{c}{ }_{13}^{P h} \mathrm{Cy} \\
(>95 \%)^{*}\end{array}$ \\
\hline
\end{tabular}

$\left(^{*}\right)$ Yield of 13 was obtained by ${ }^{1} \mathrm{H}$ NMR using methyl benzoate as an internal standard. 


\section{Selected NMR-Spectra}
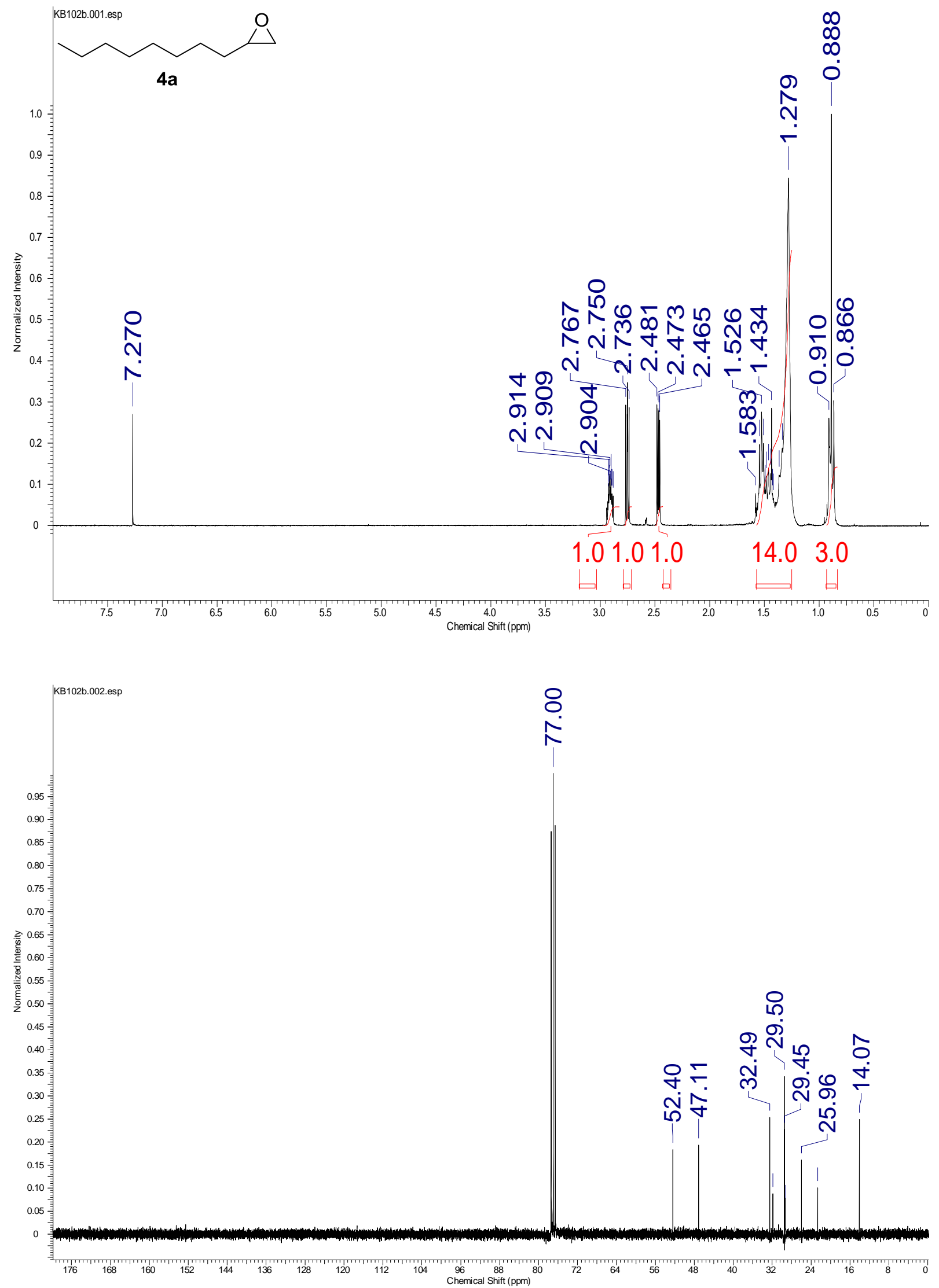

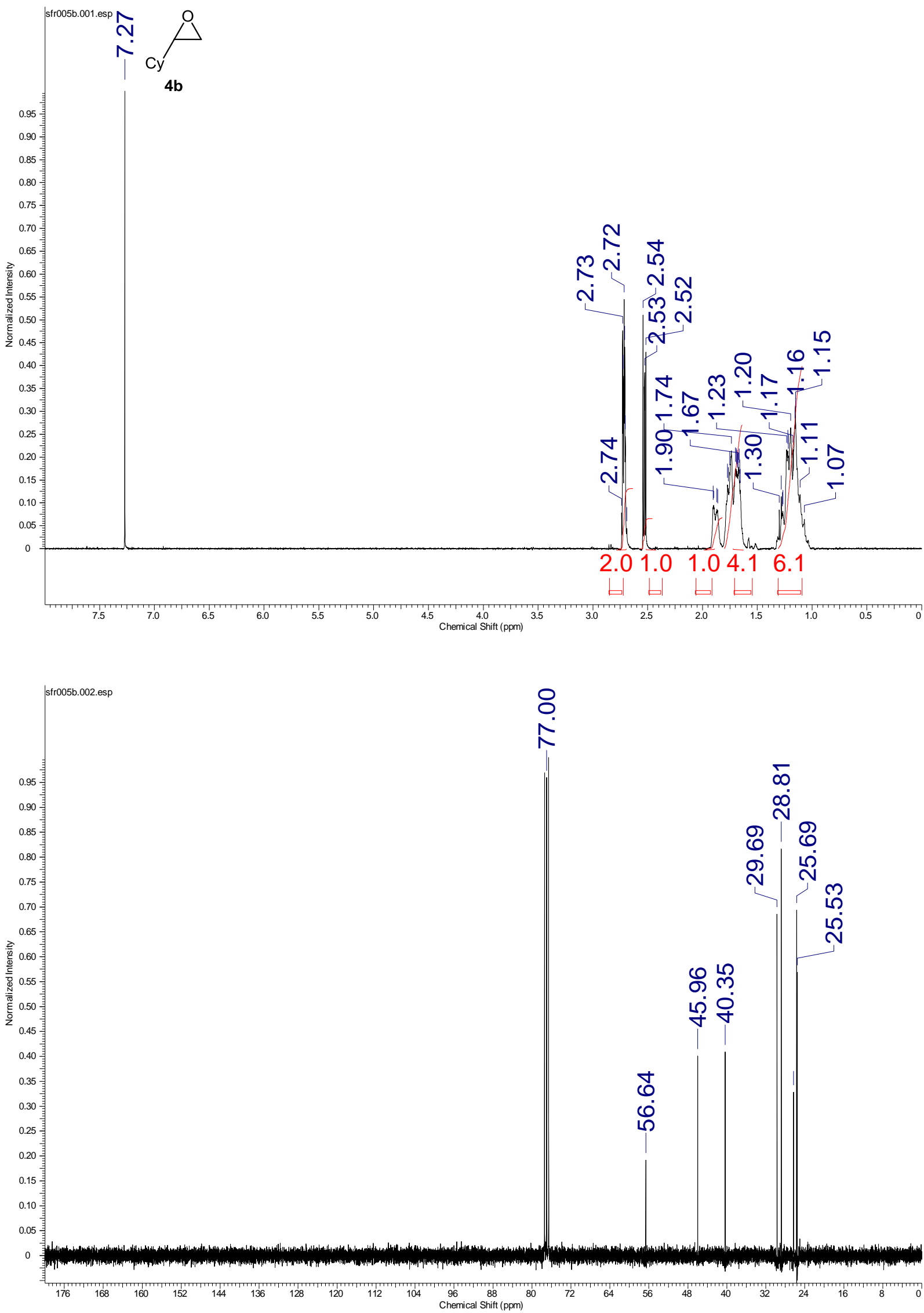

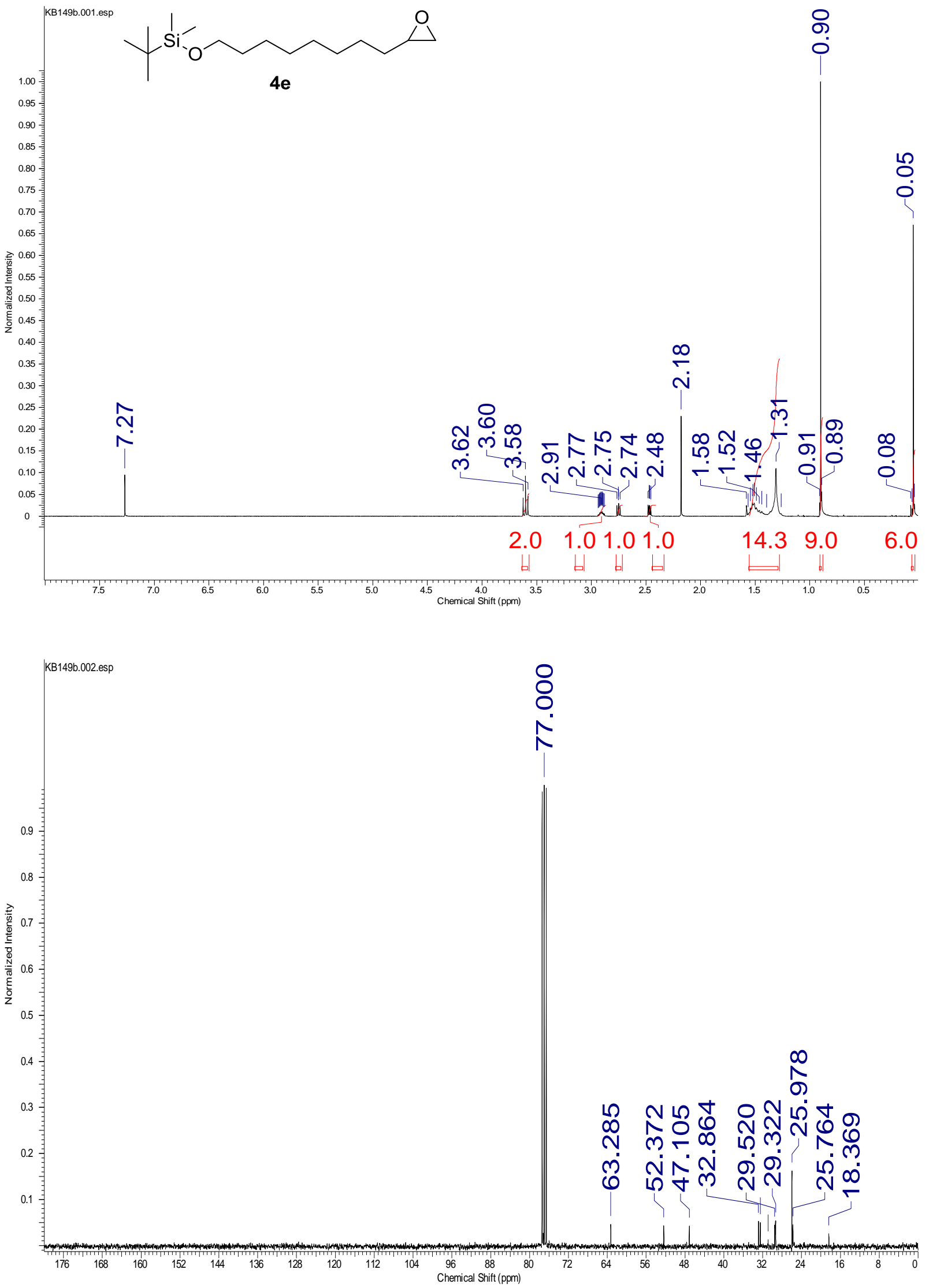

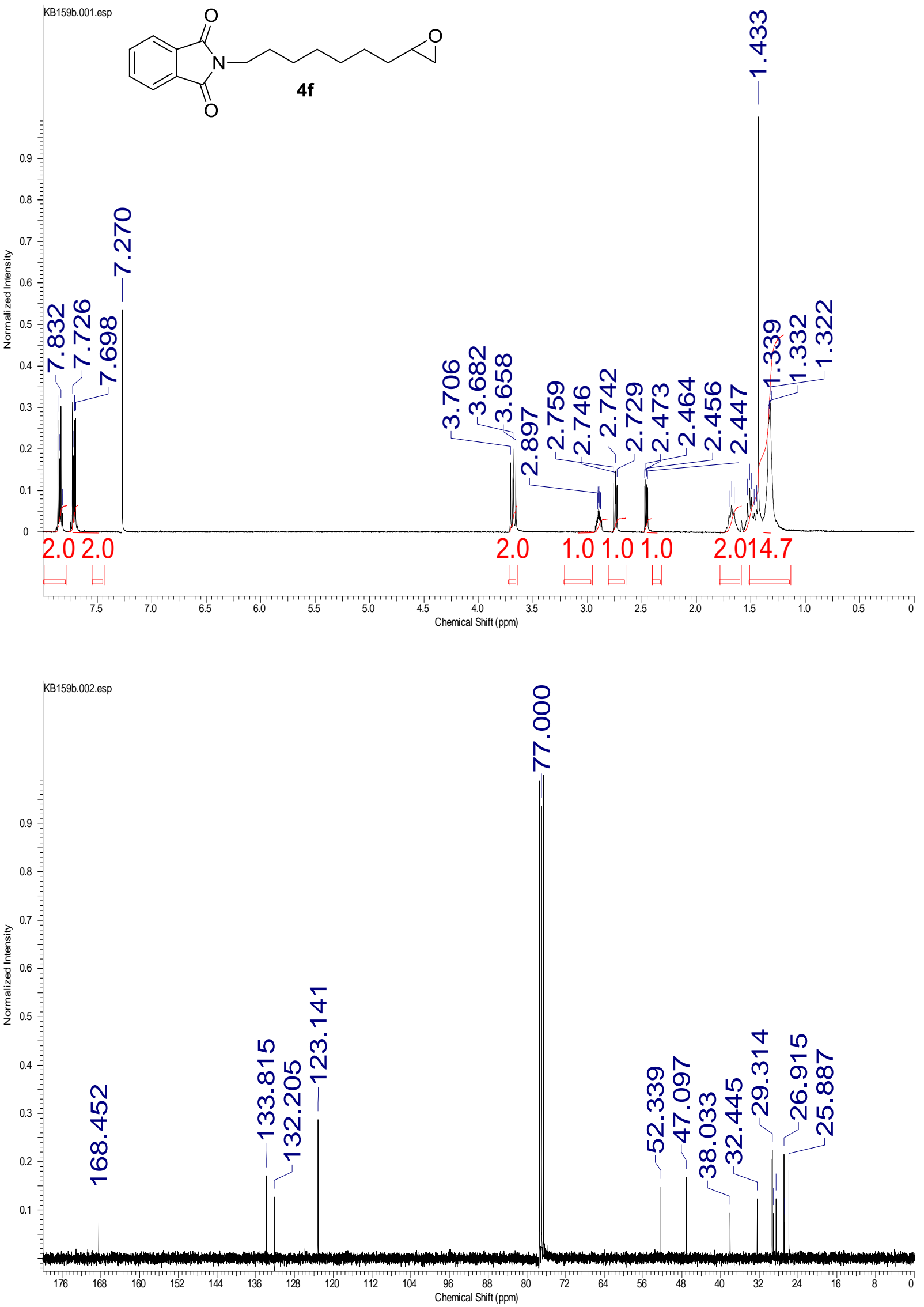

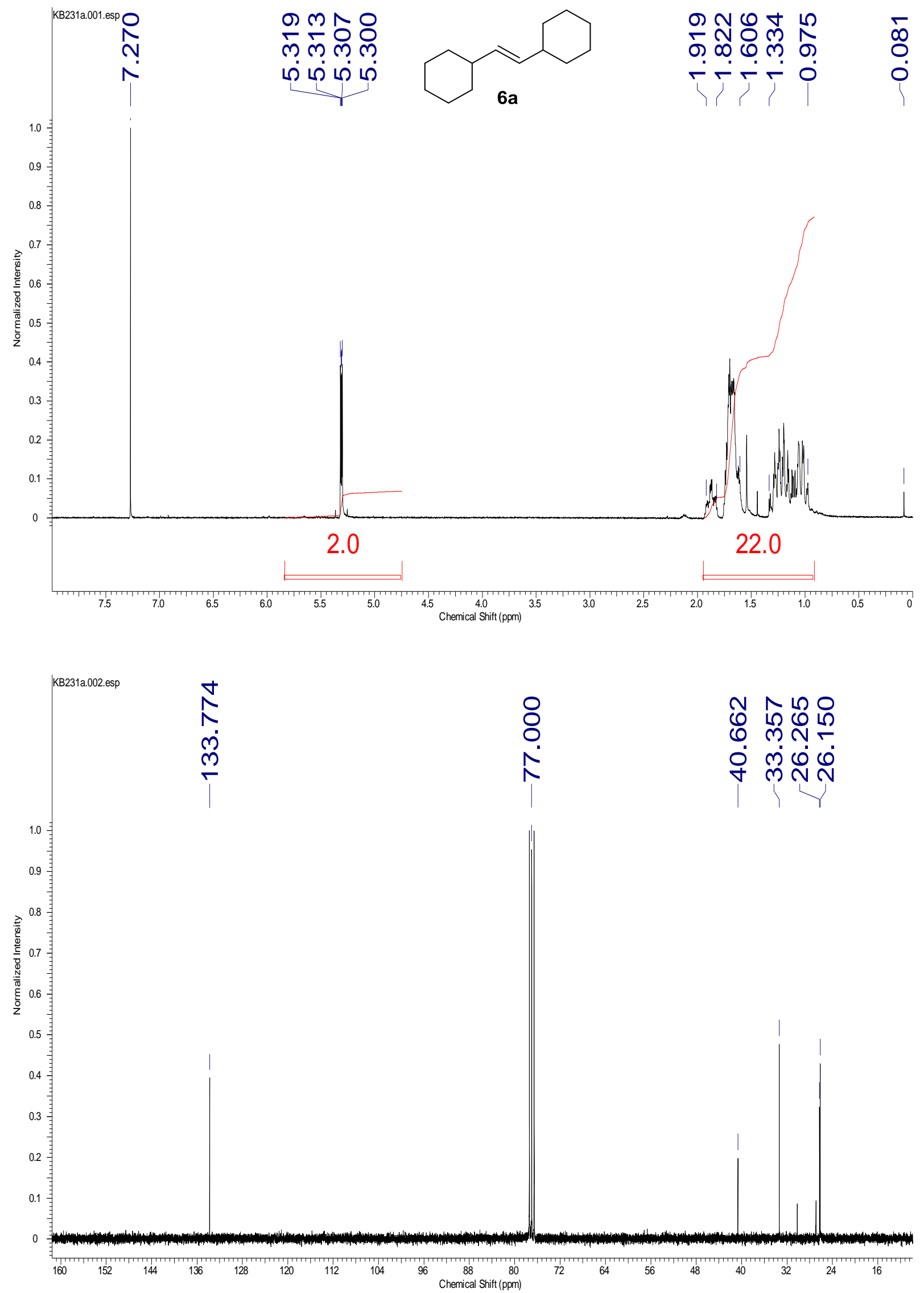

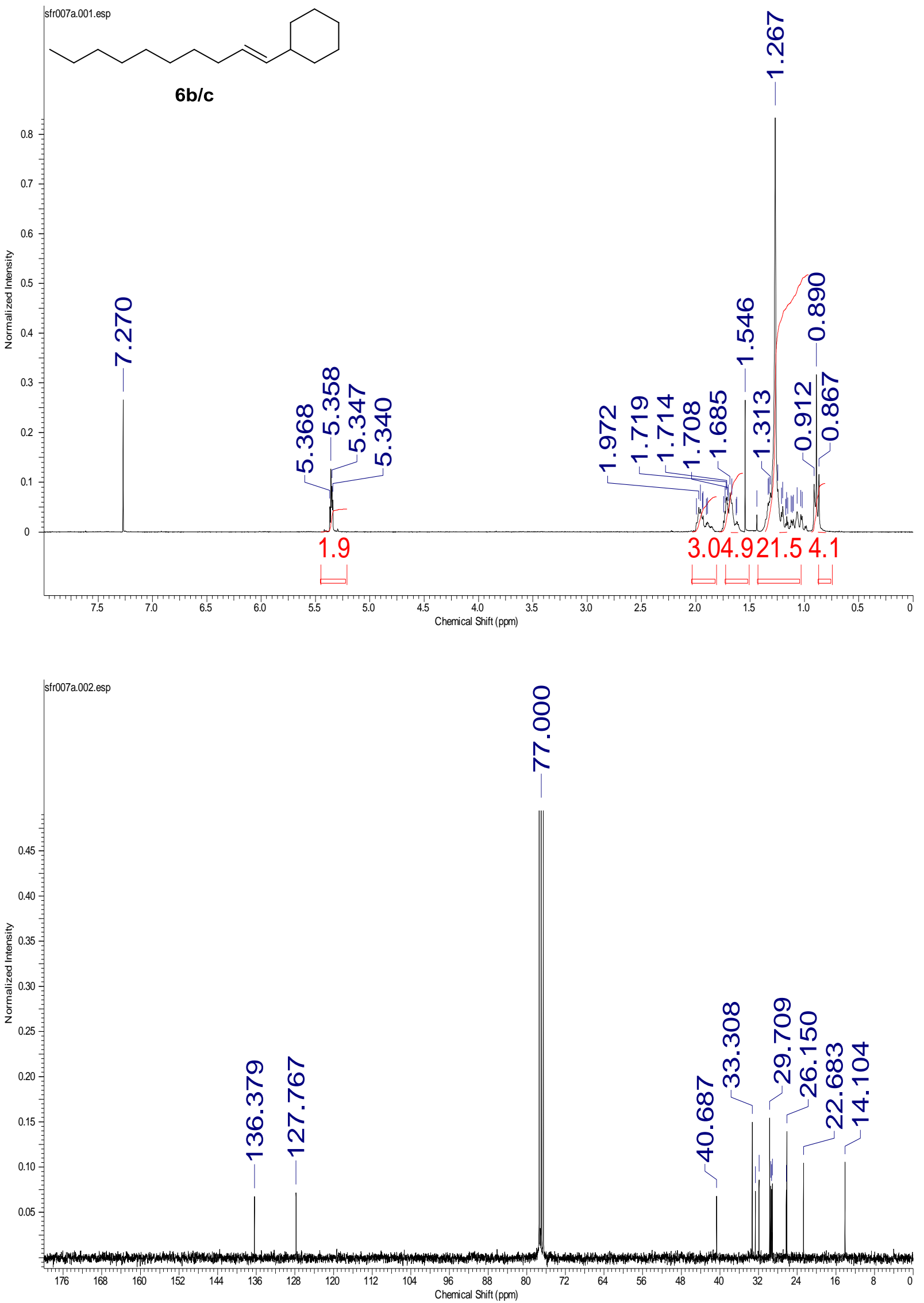

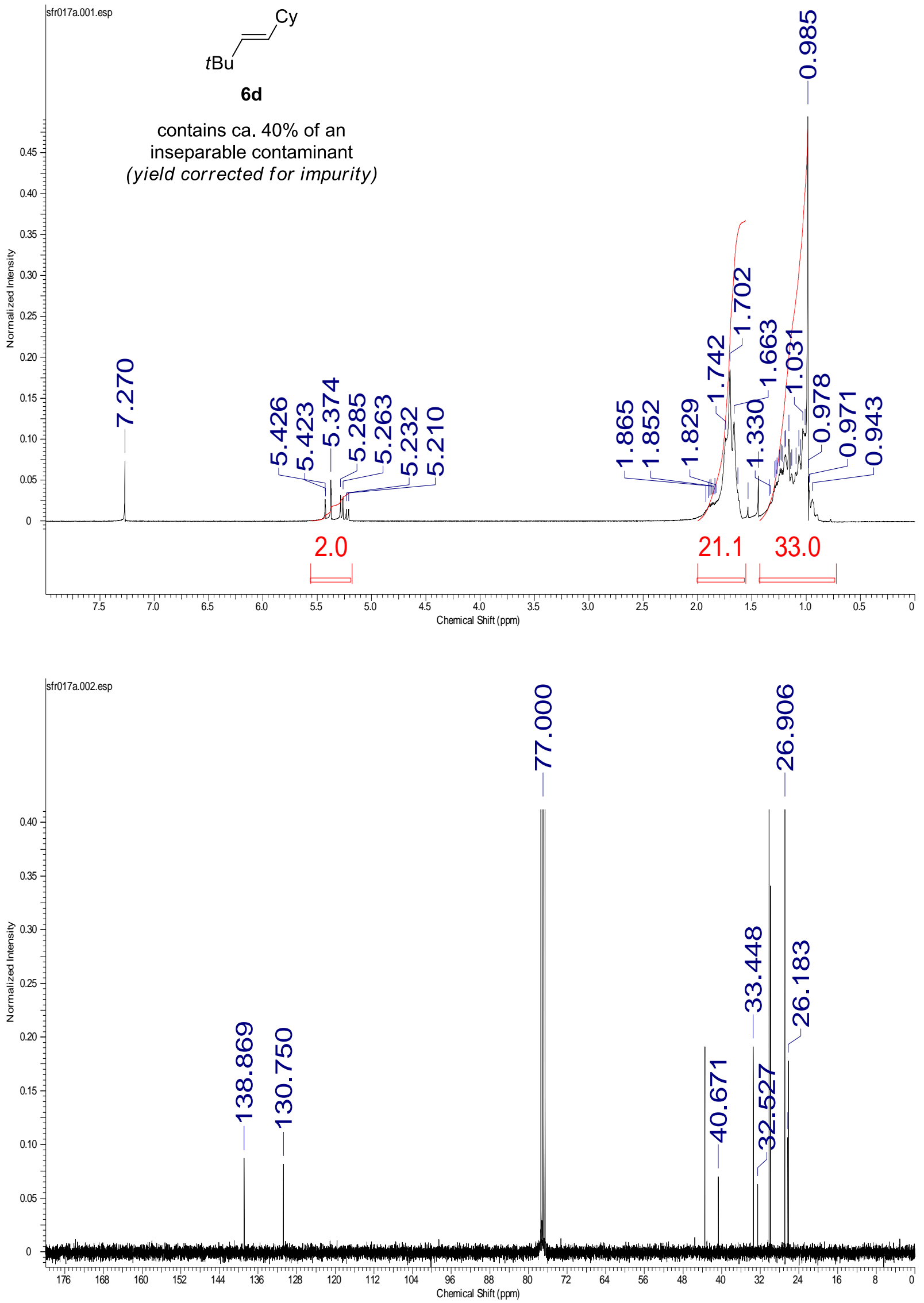

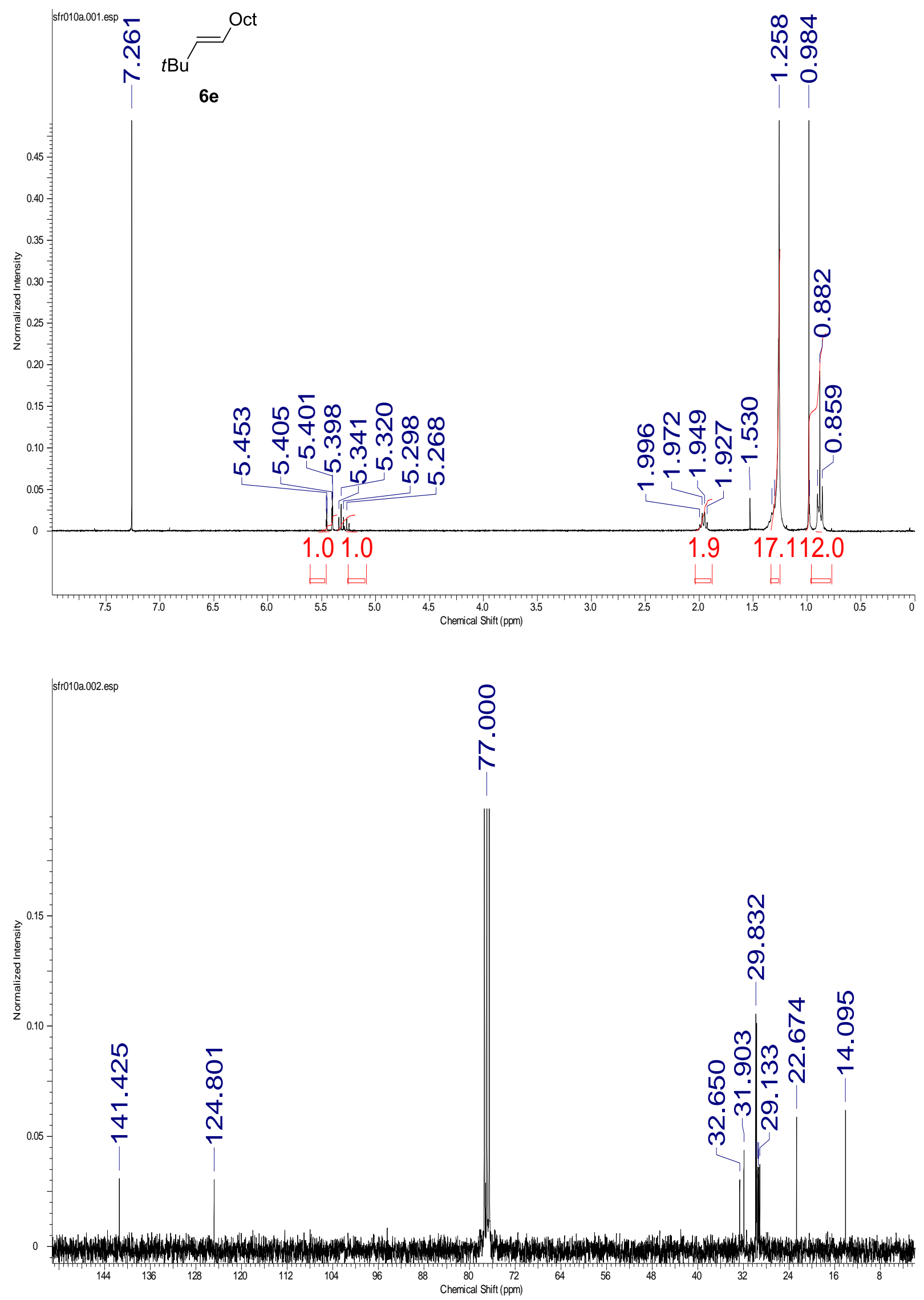

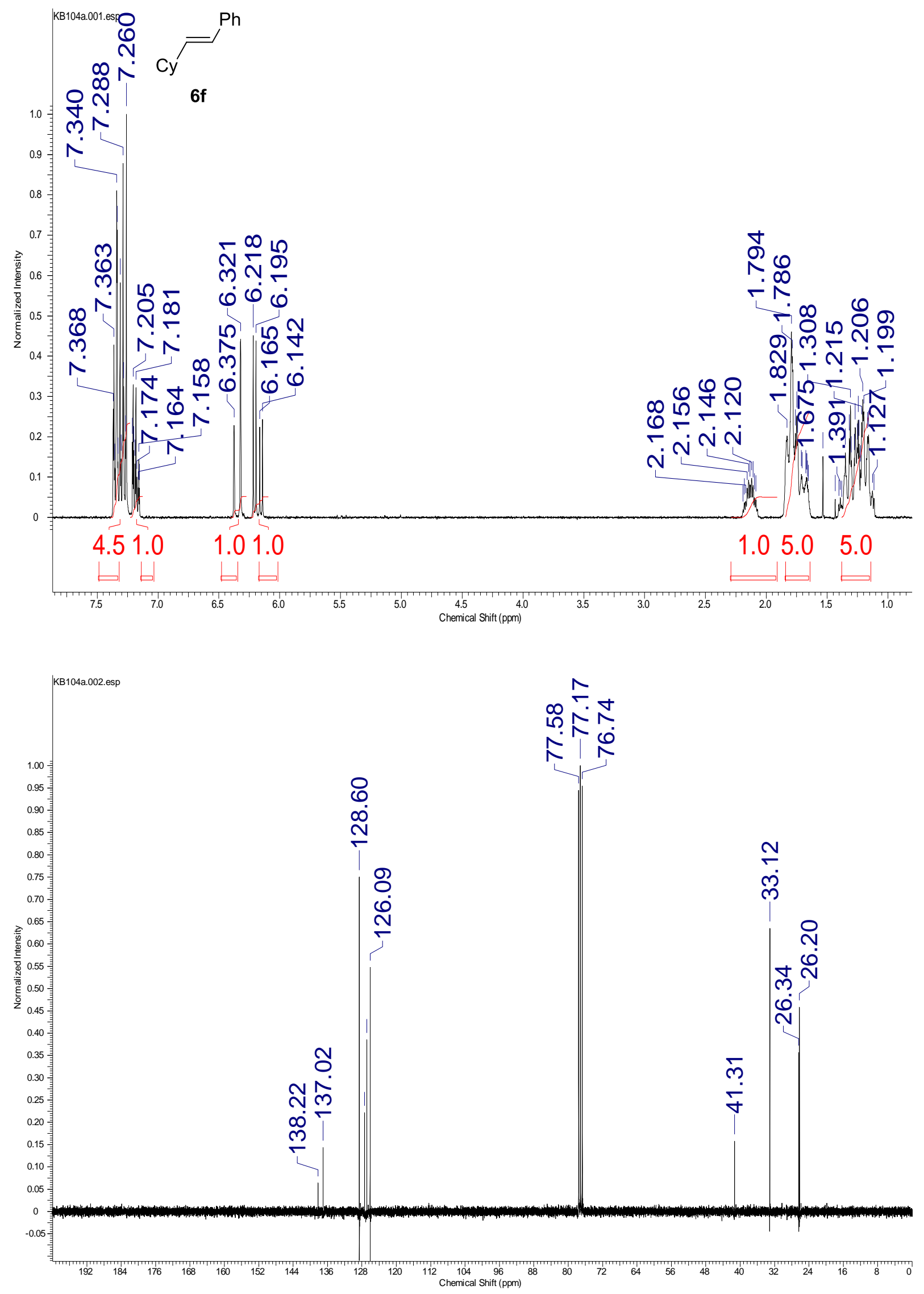

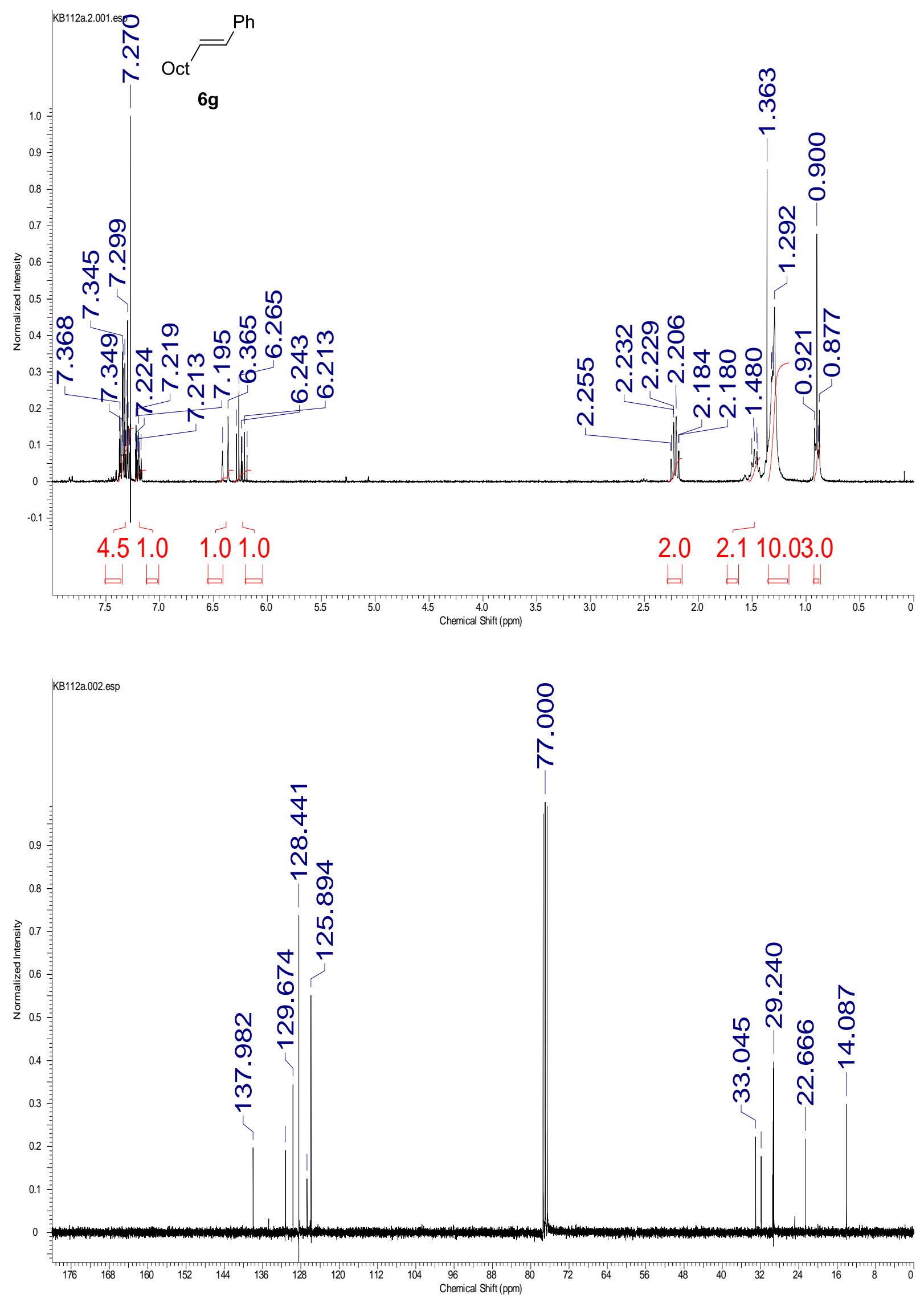

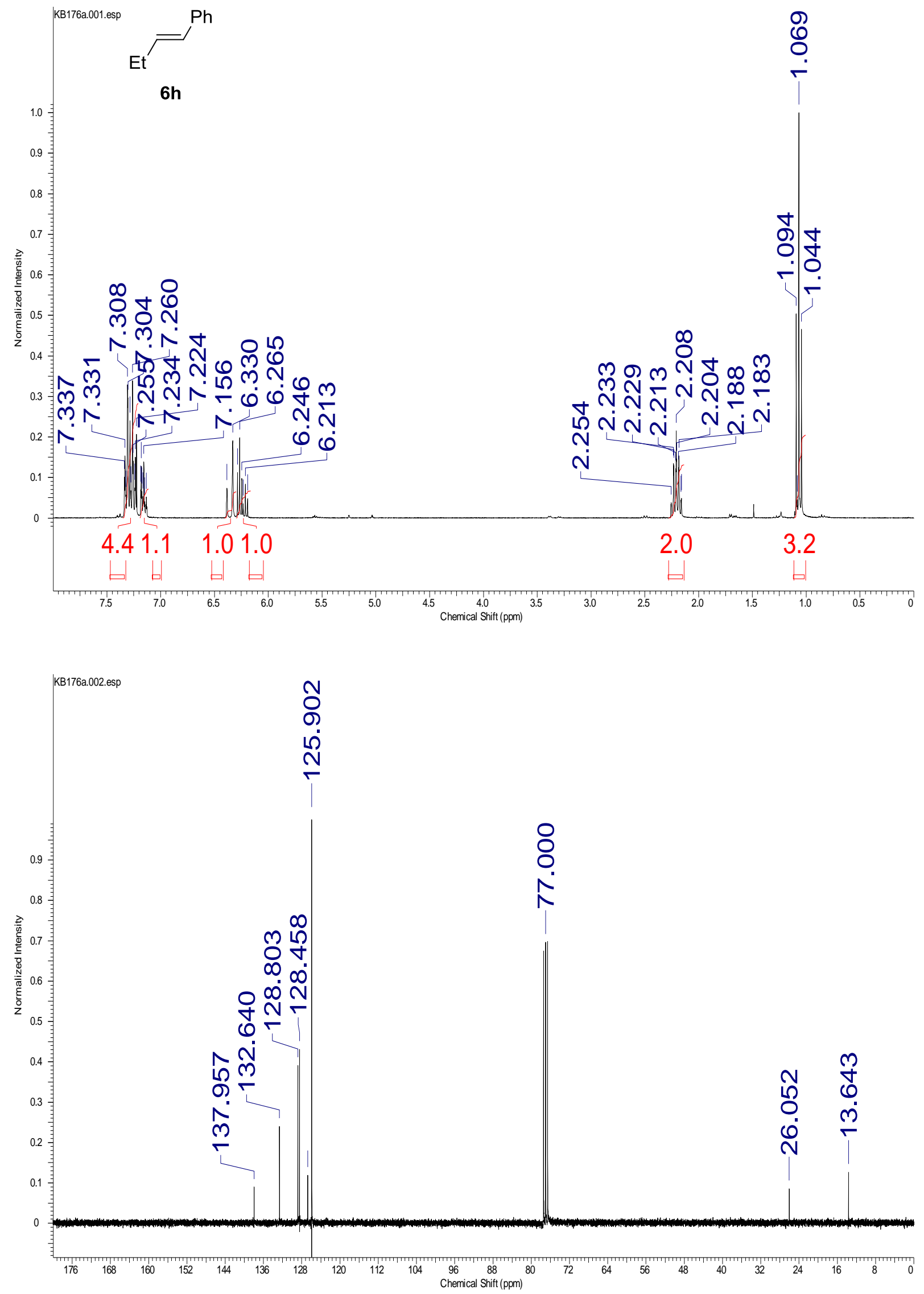

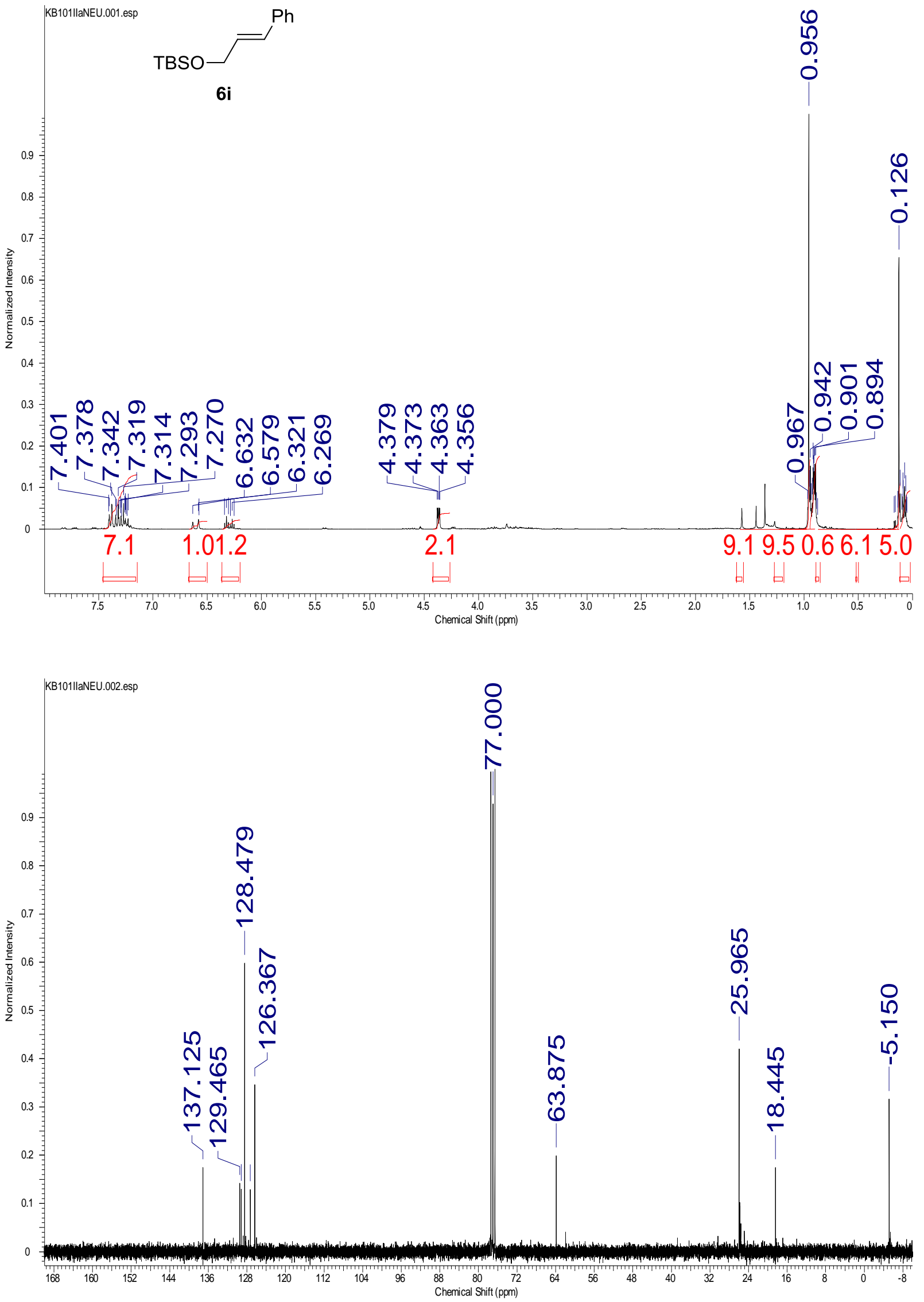

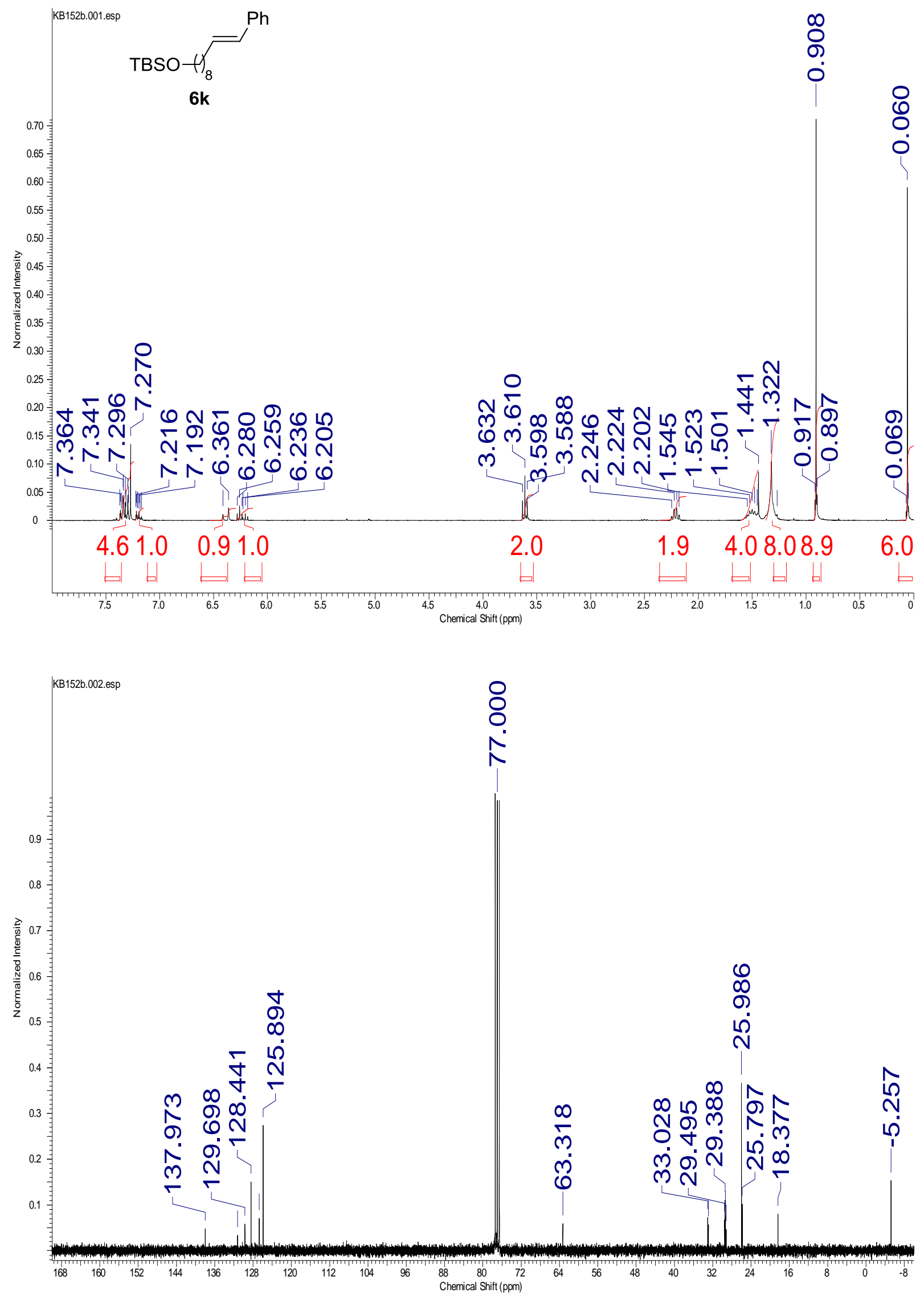

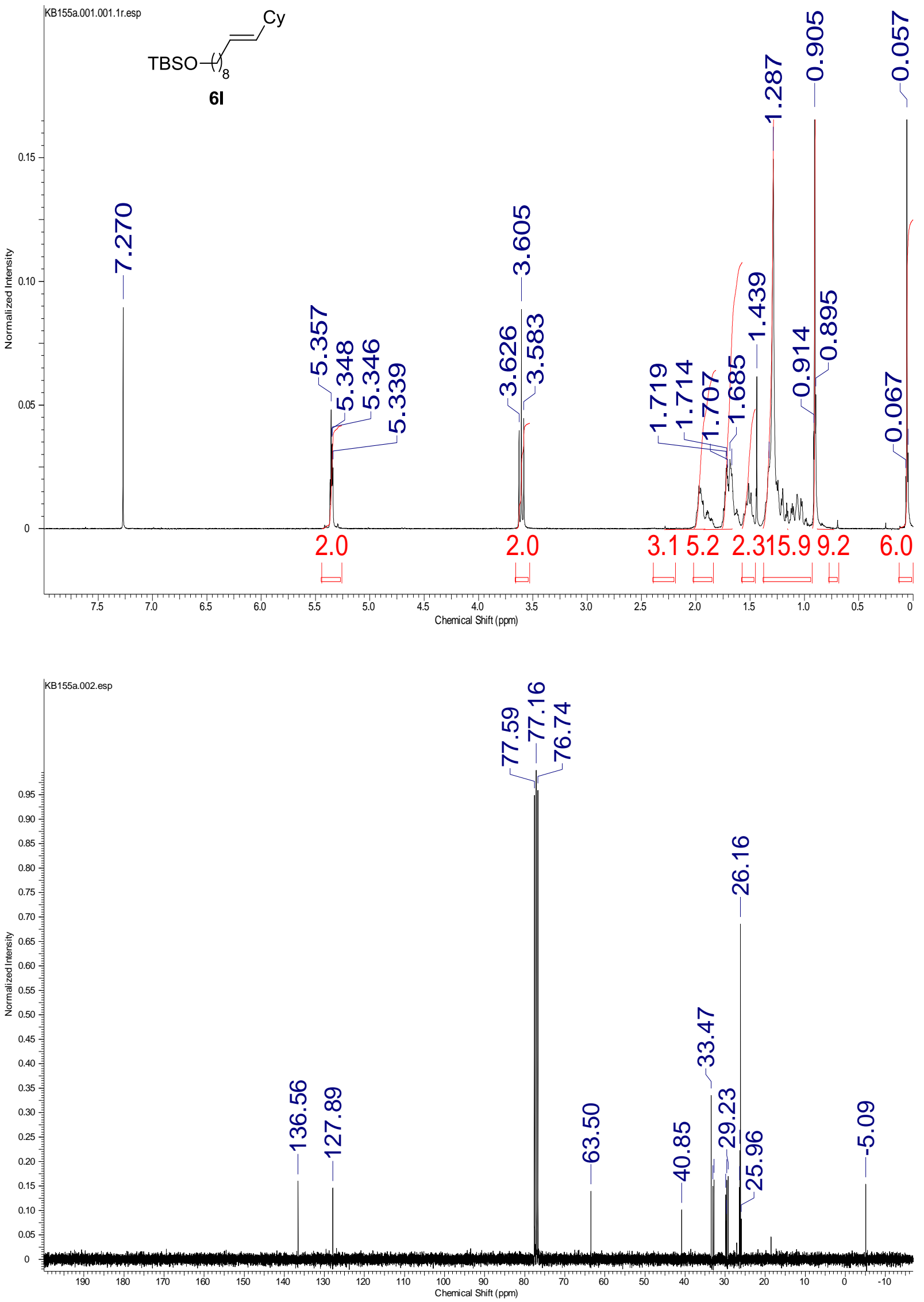

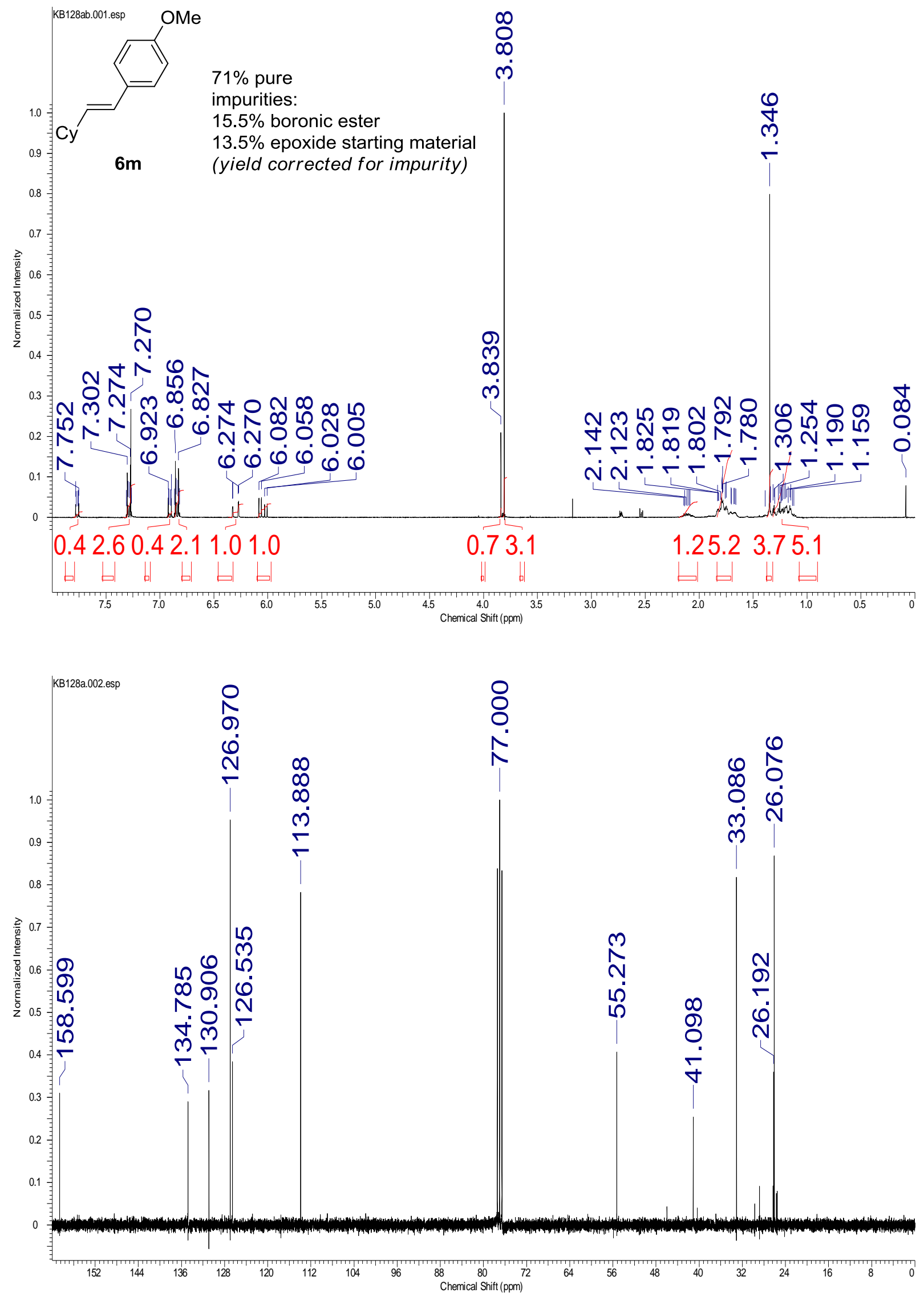

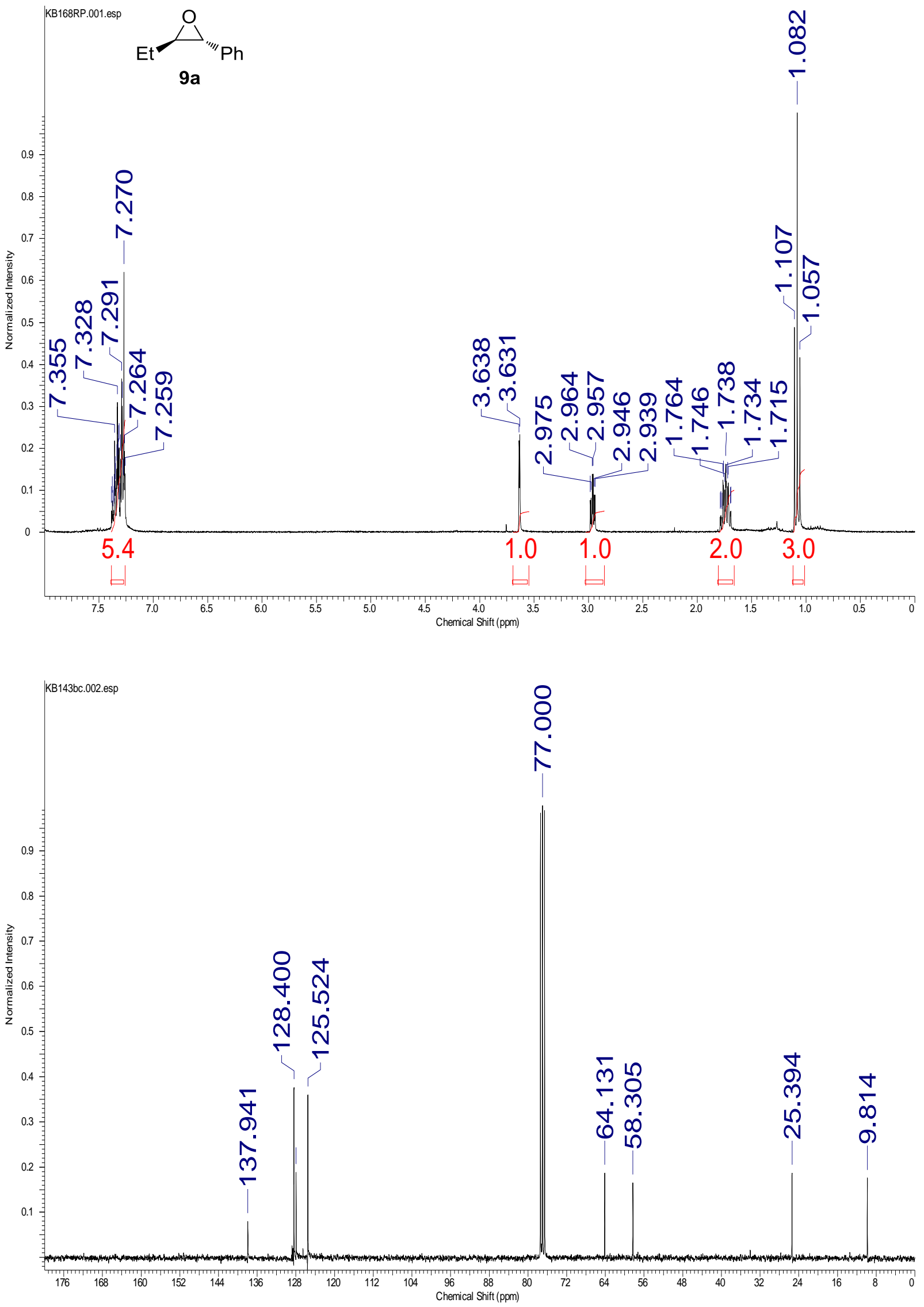

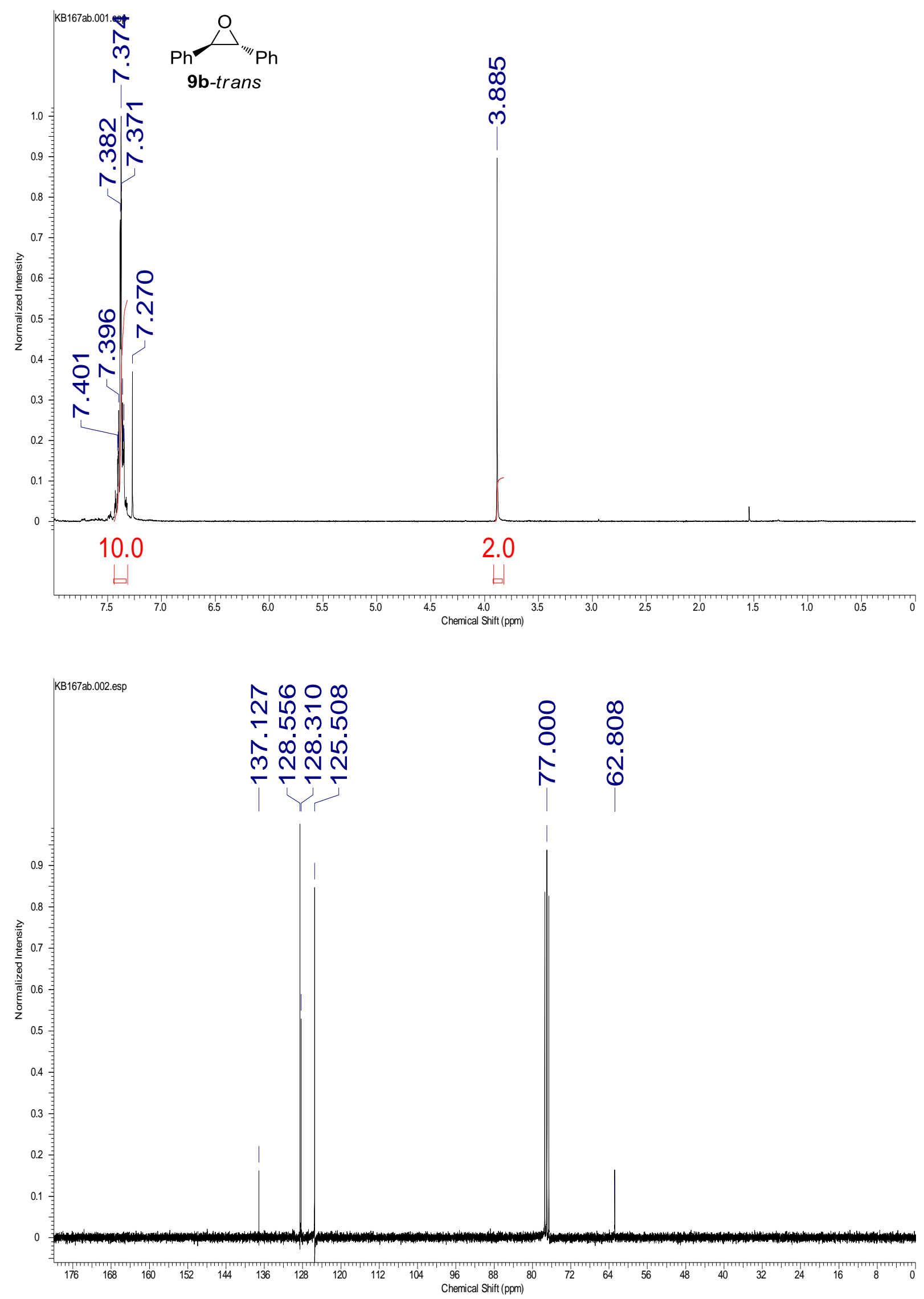

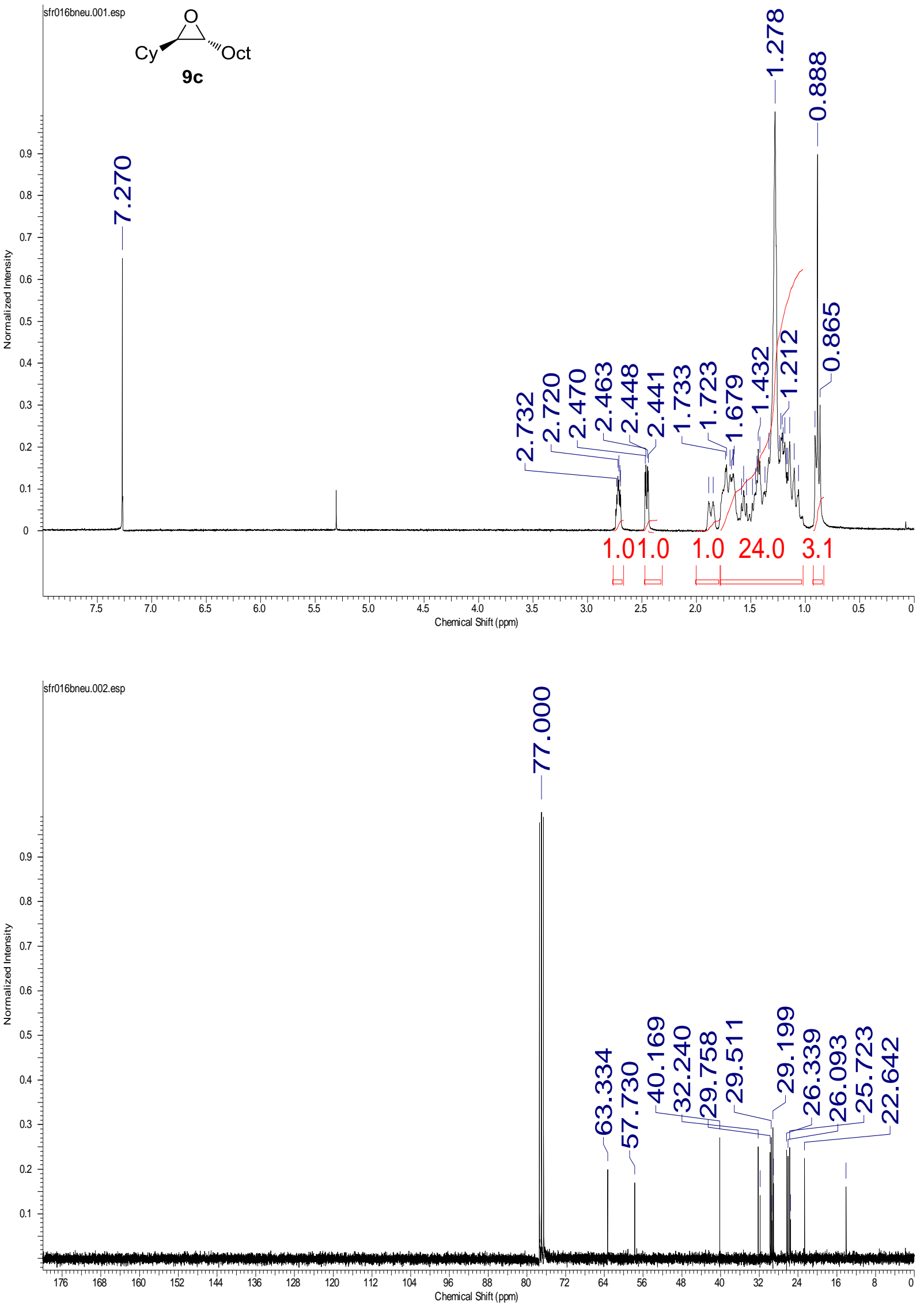

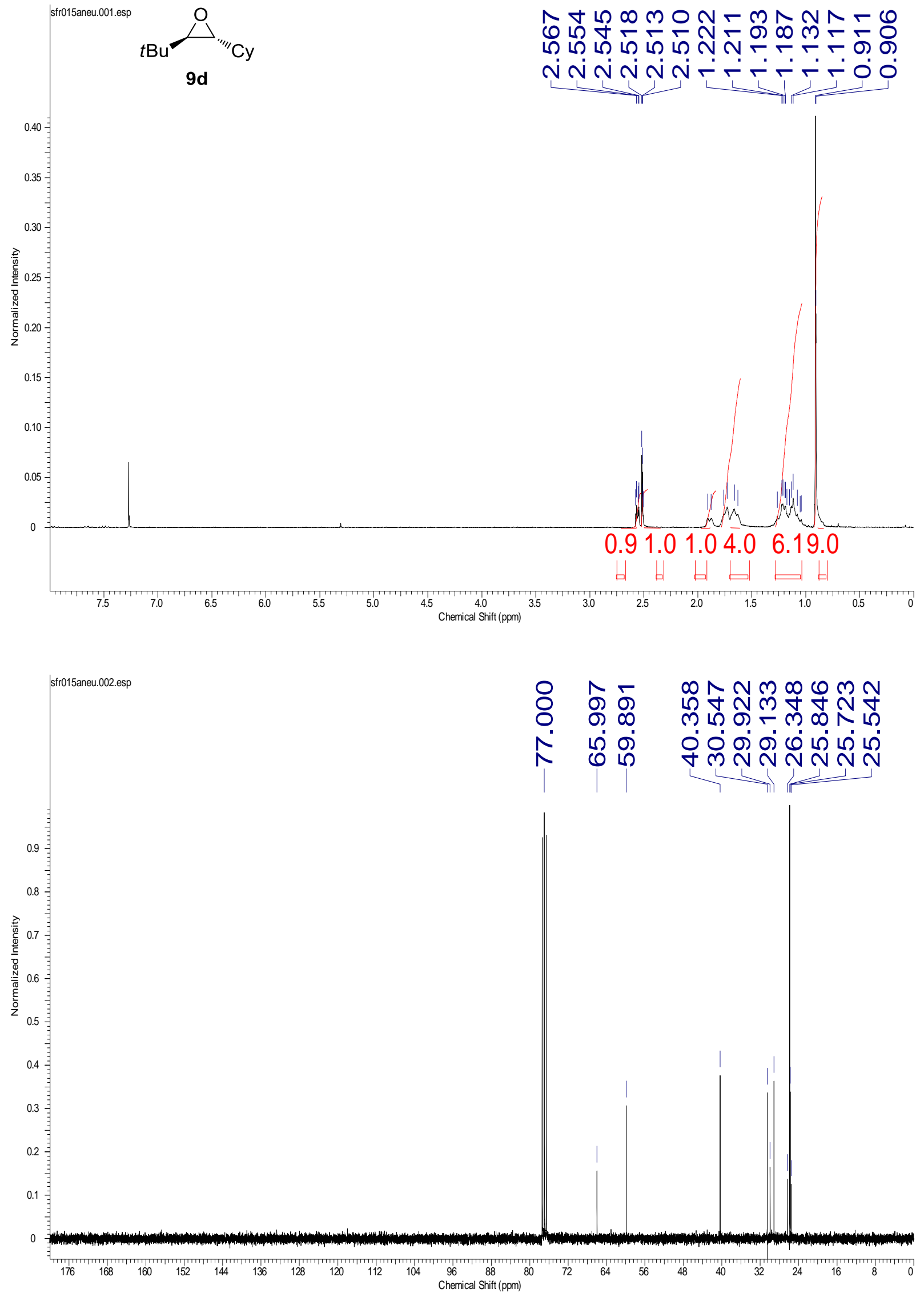

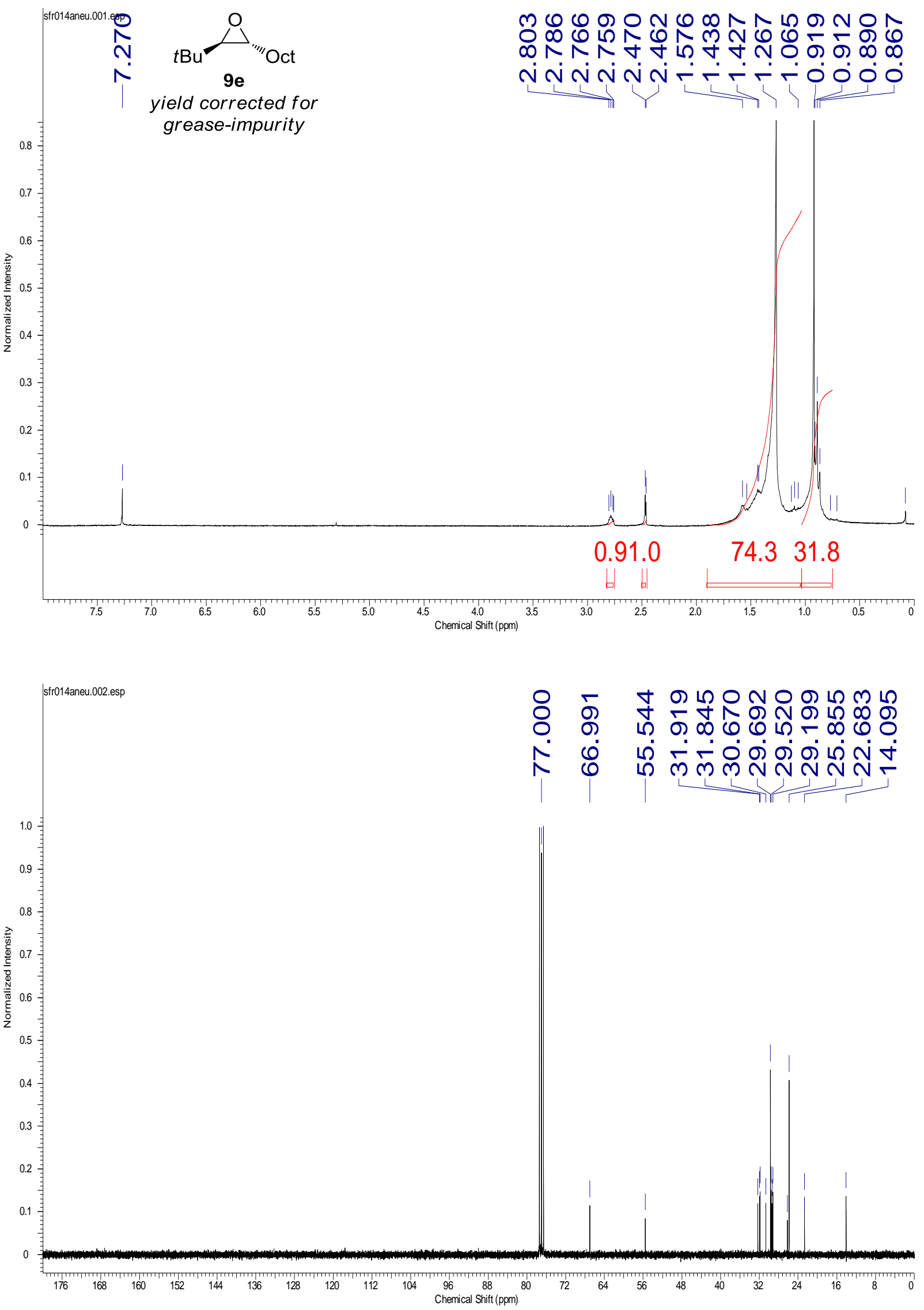

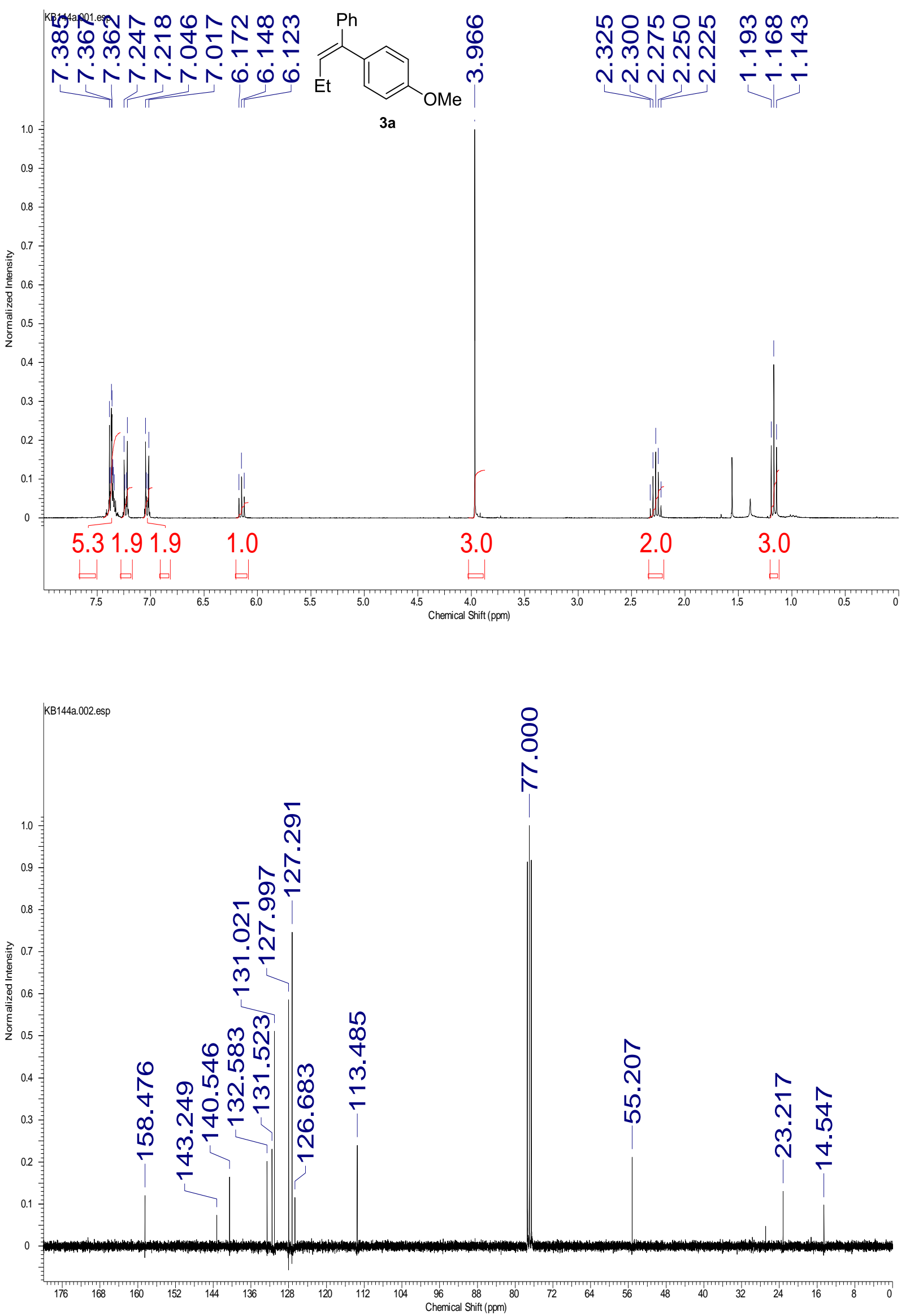

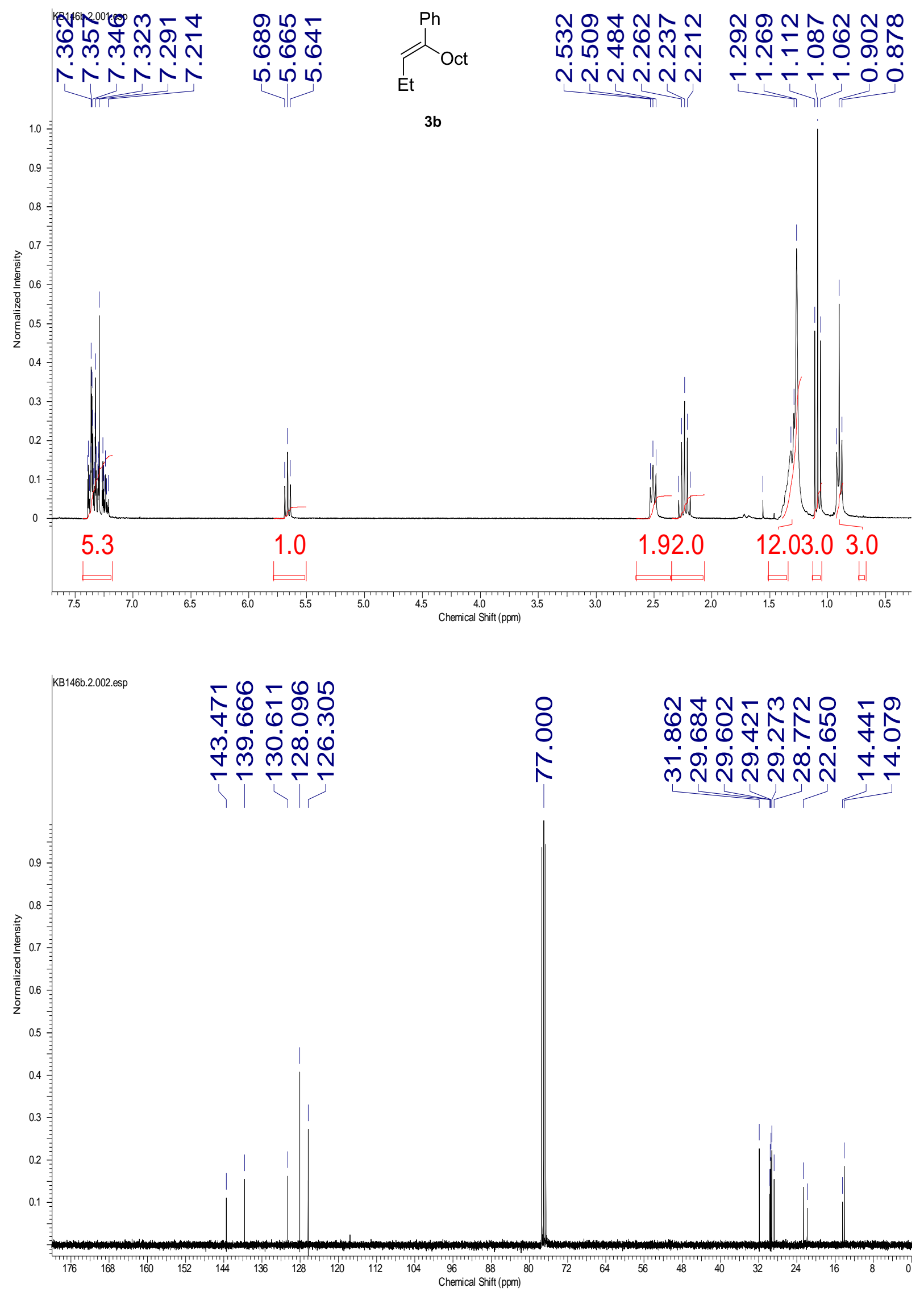

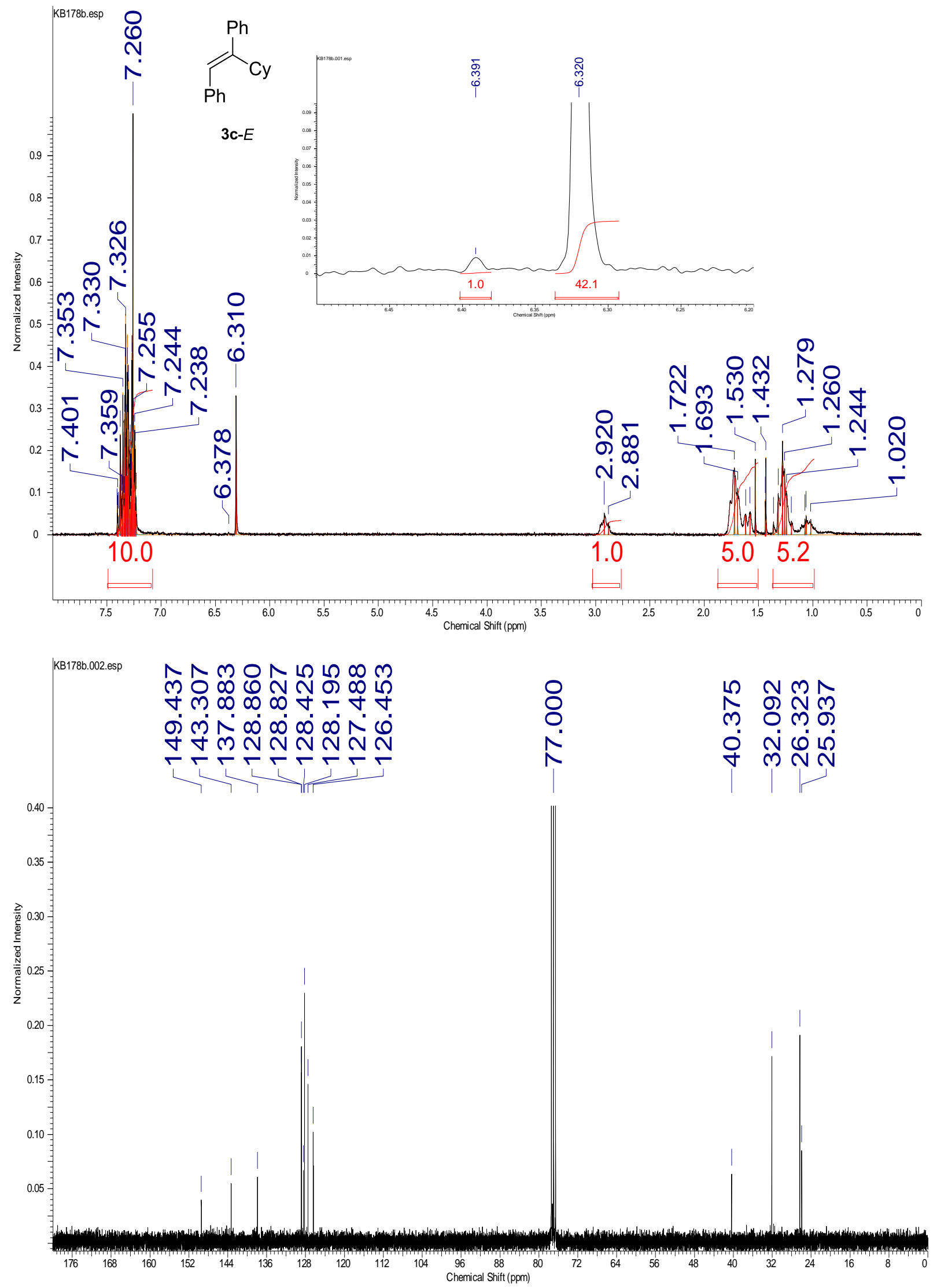

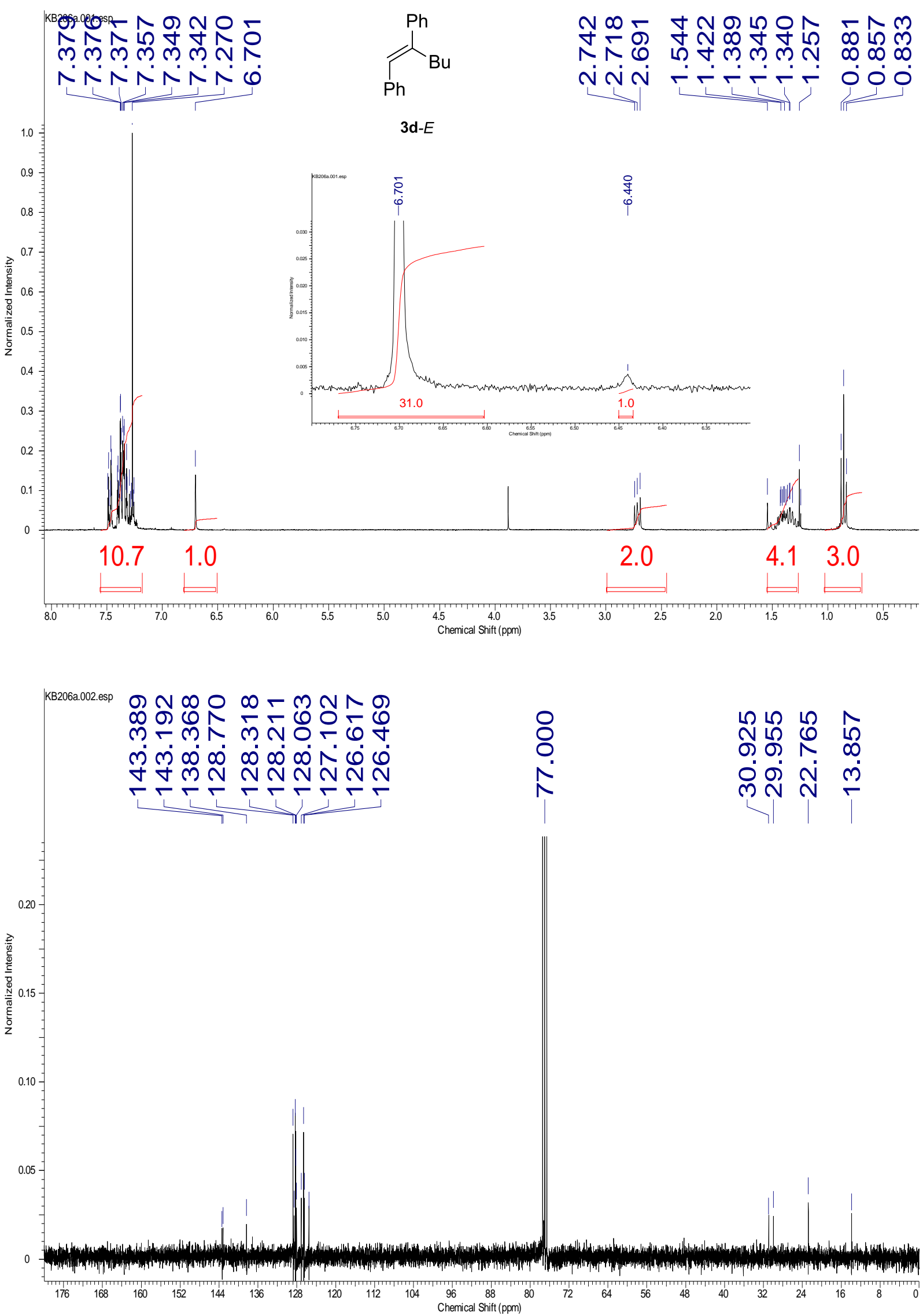

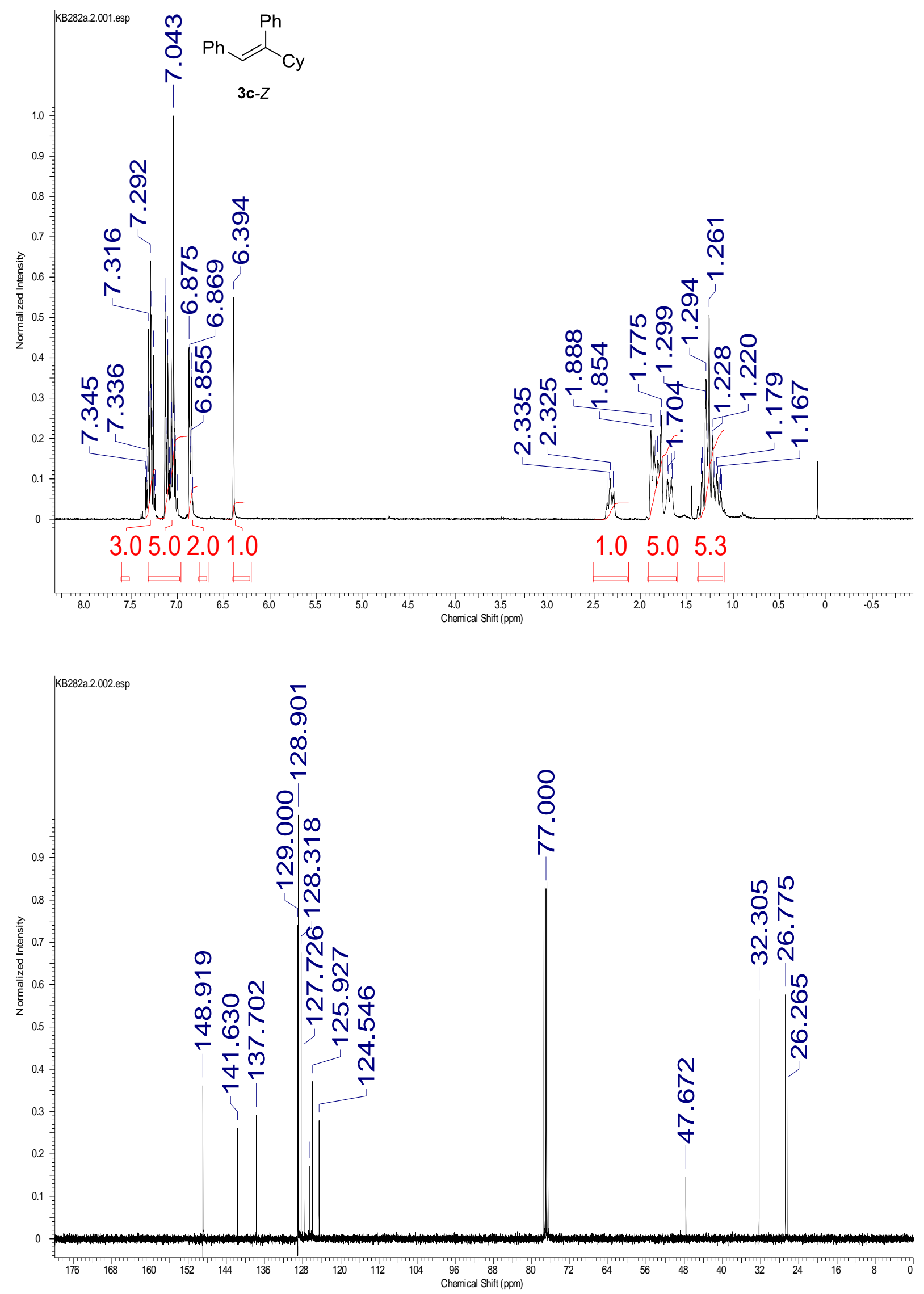

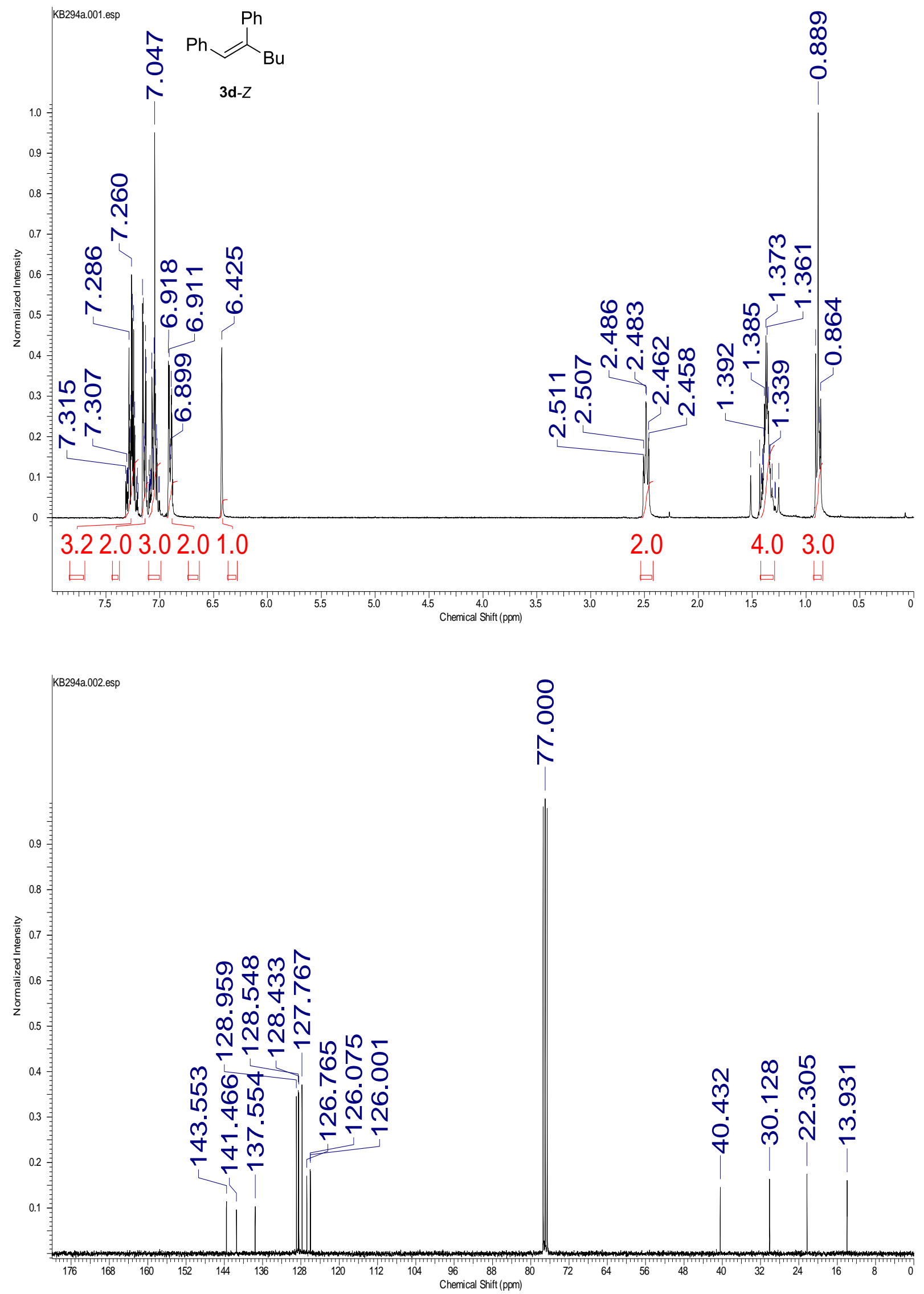

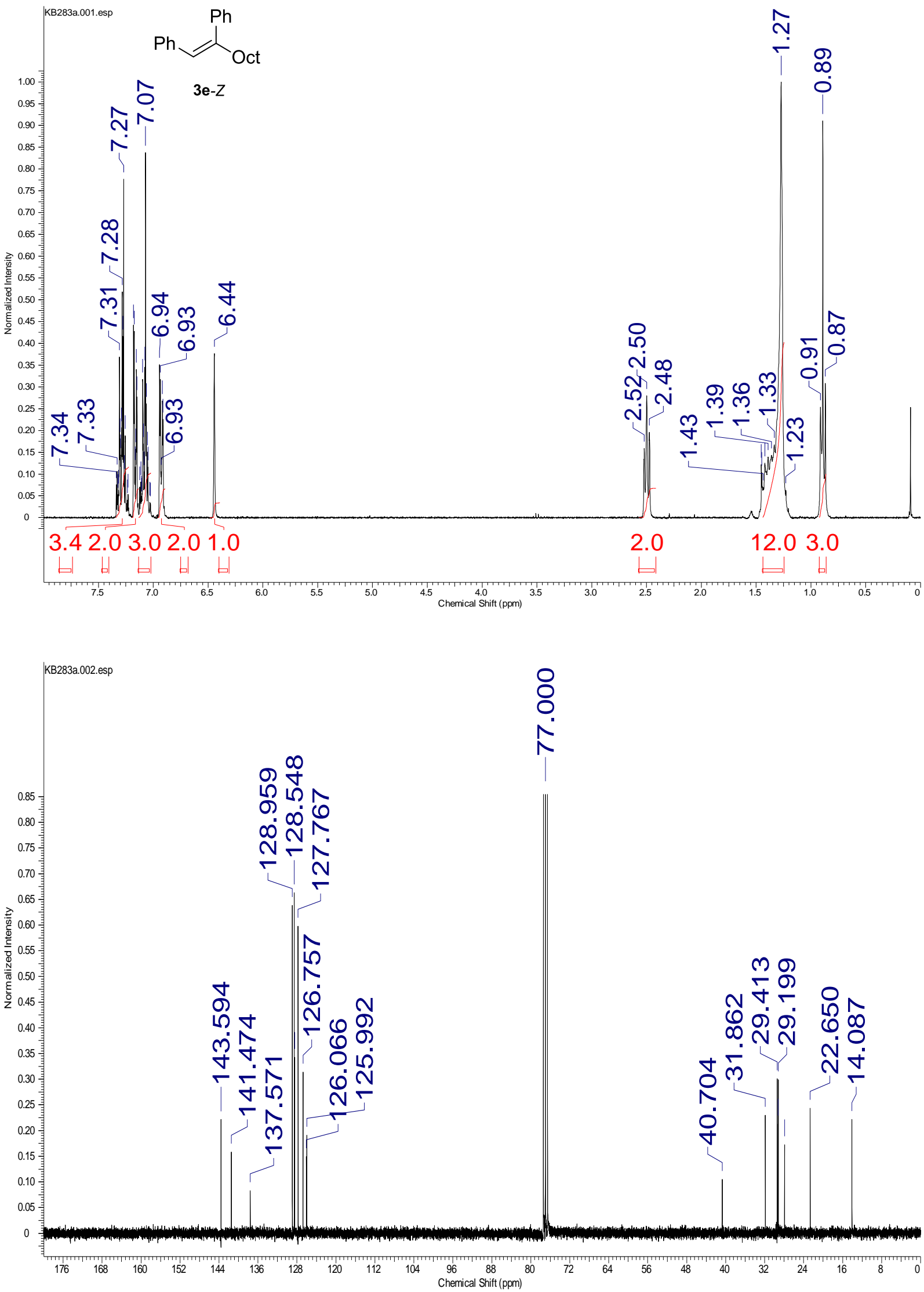

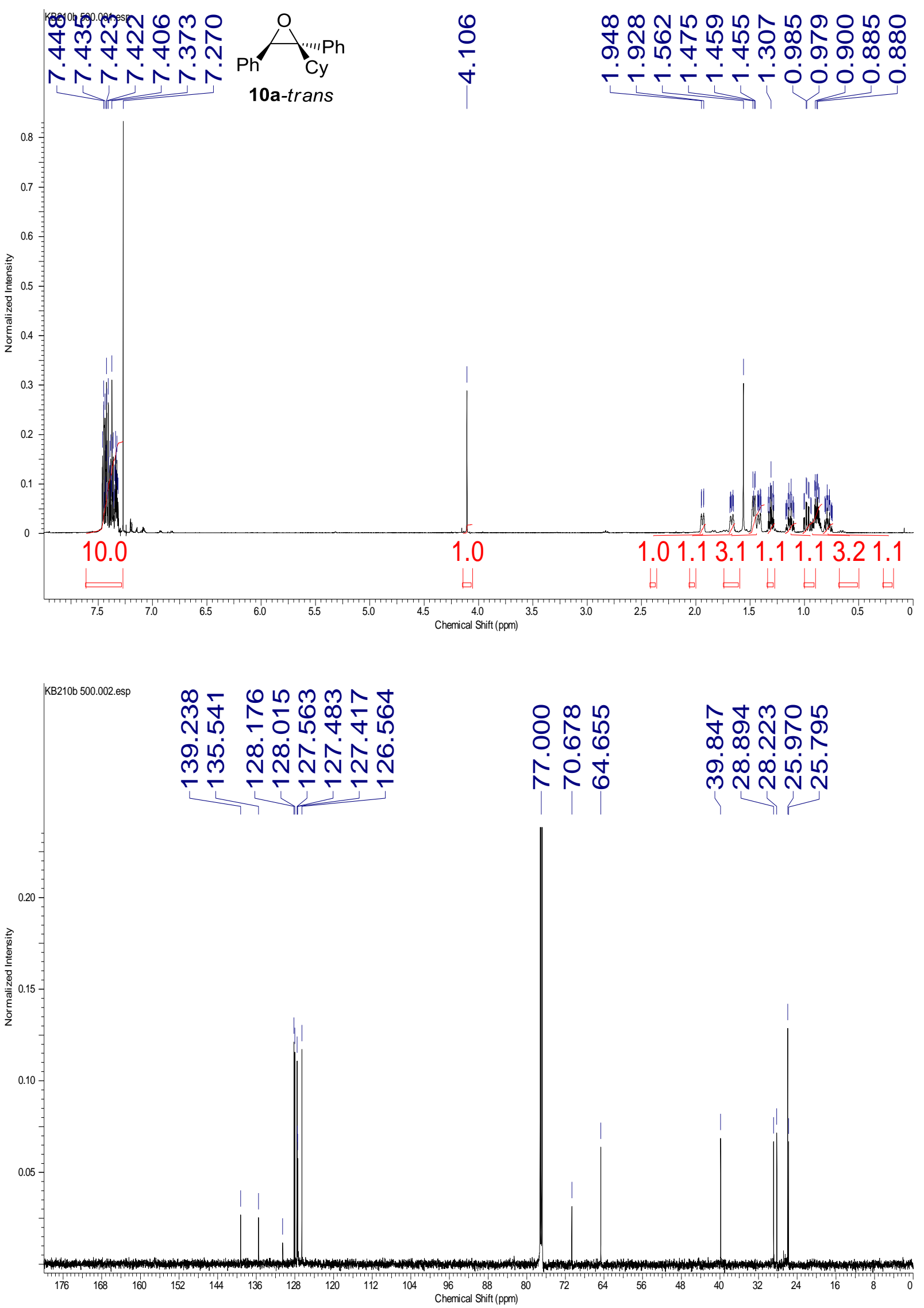

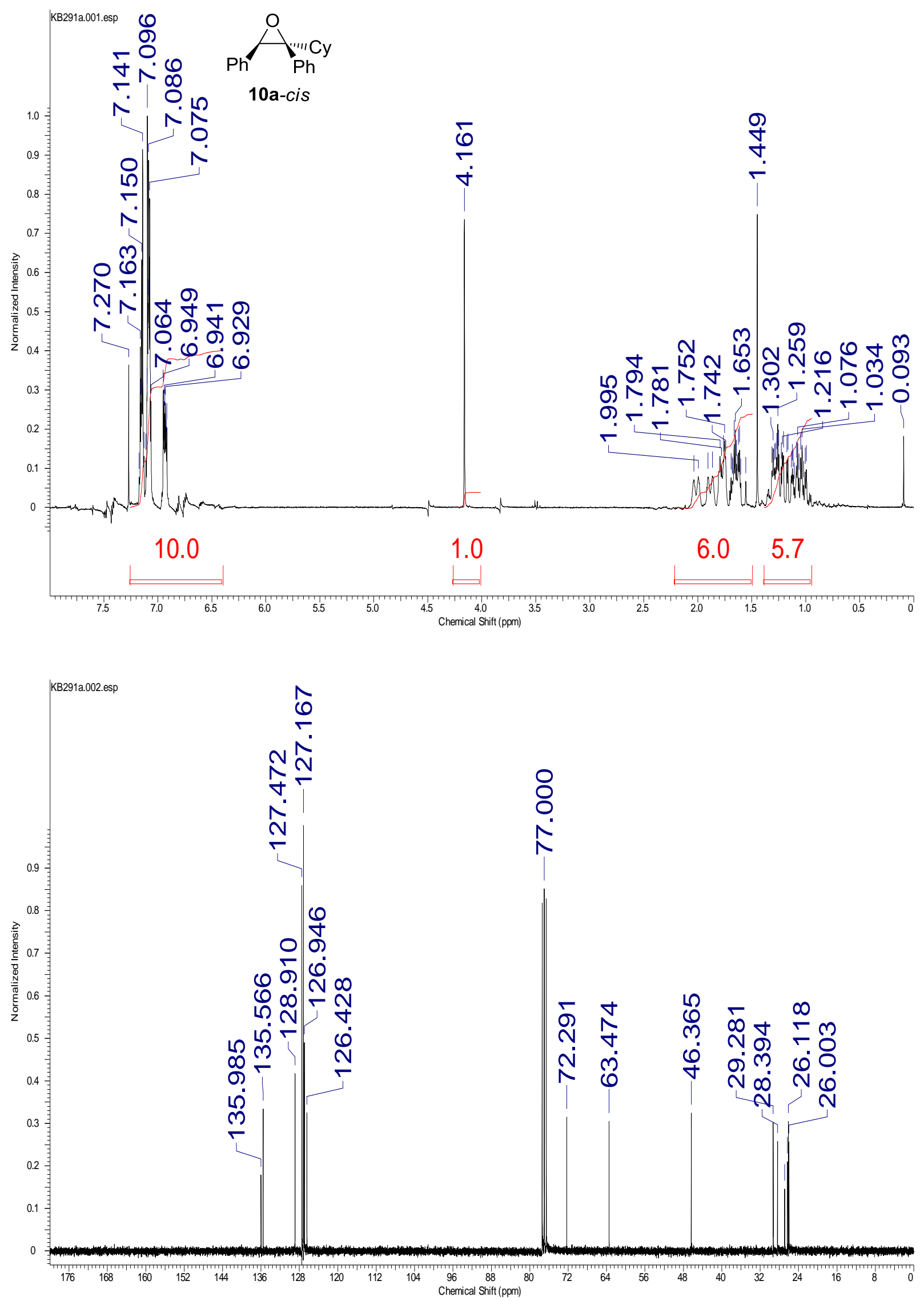

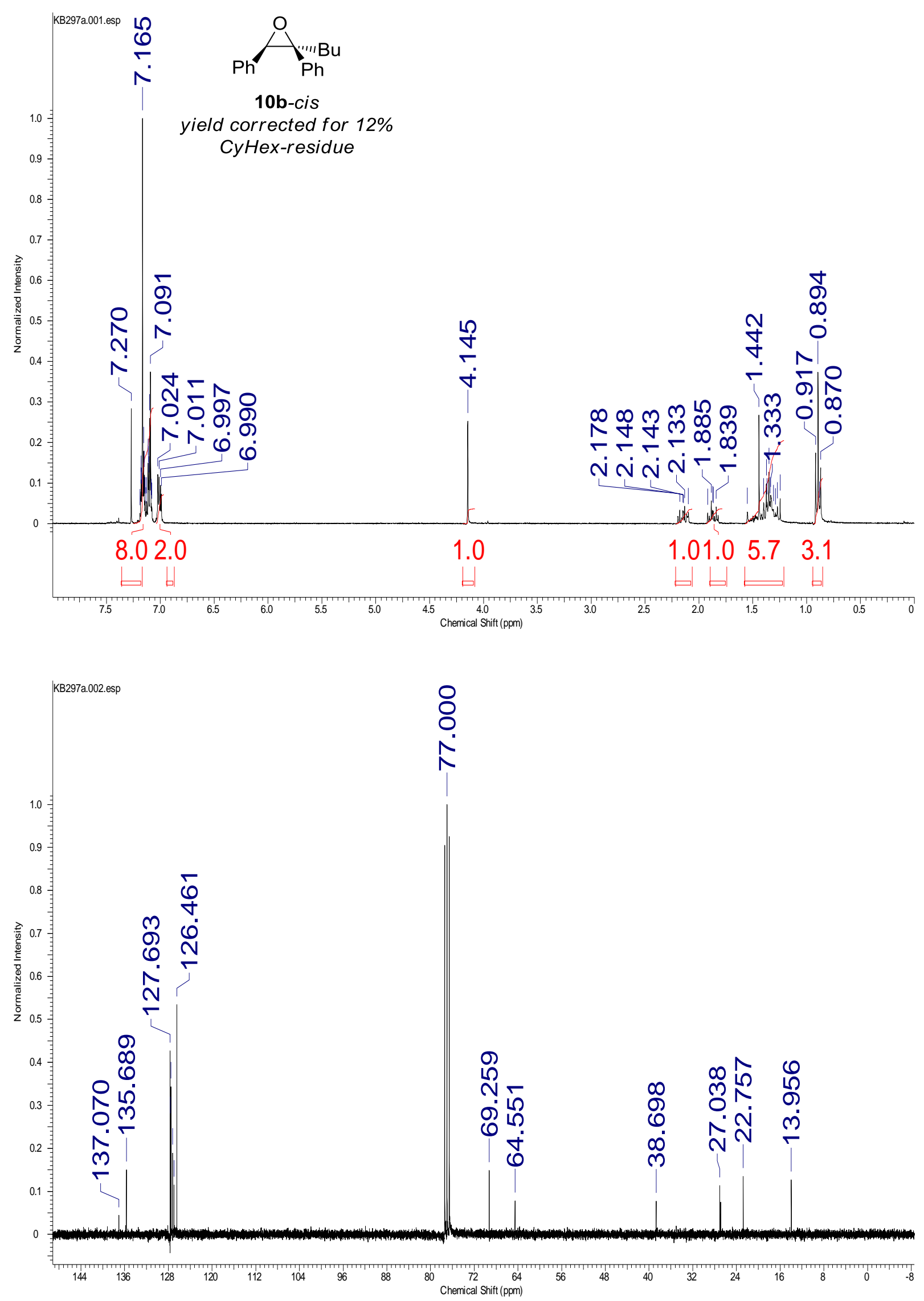

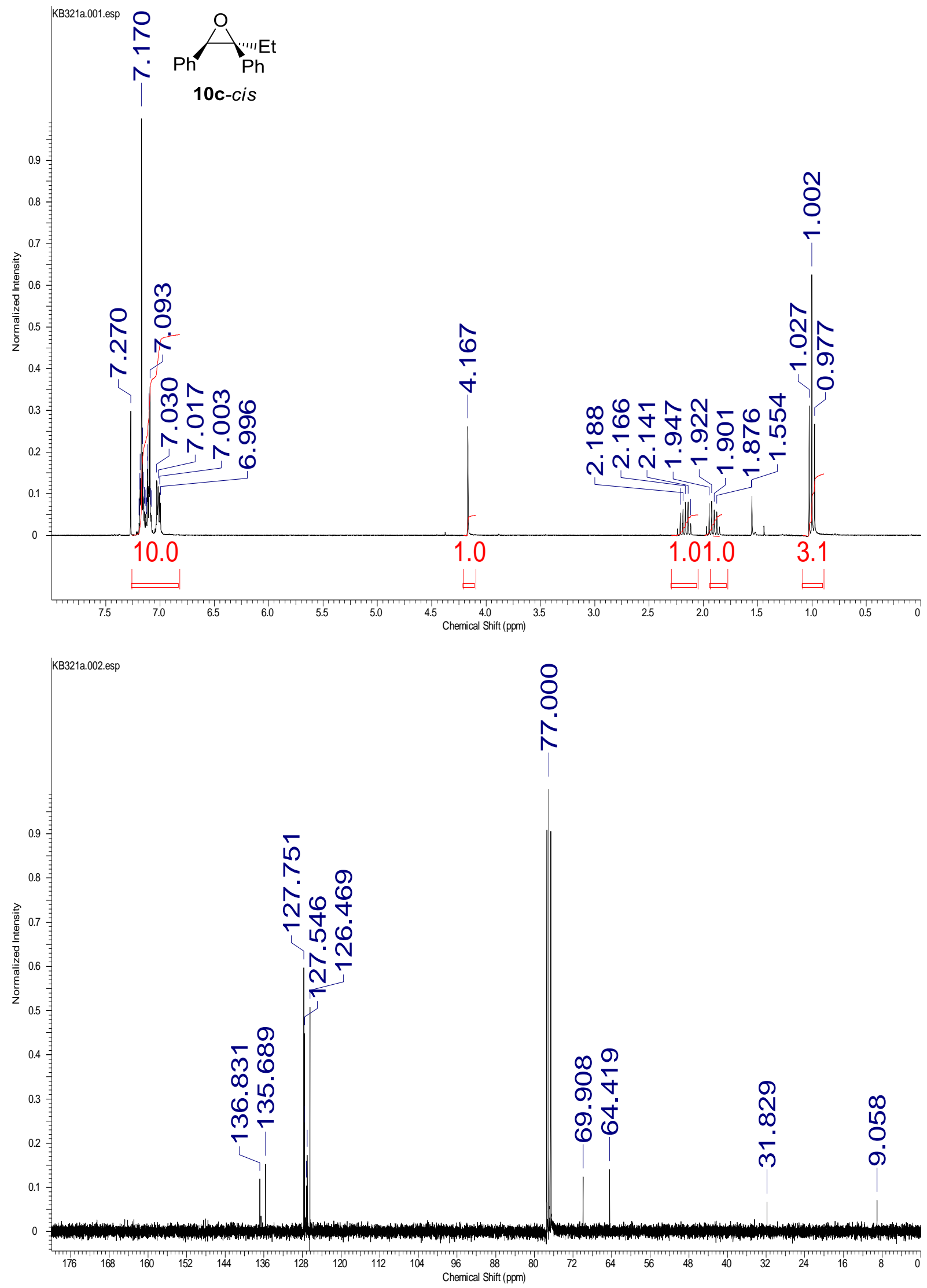

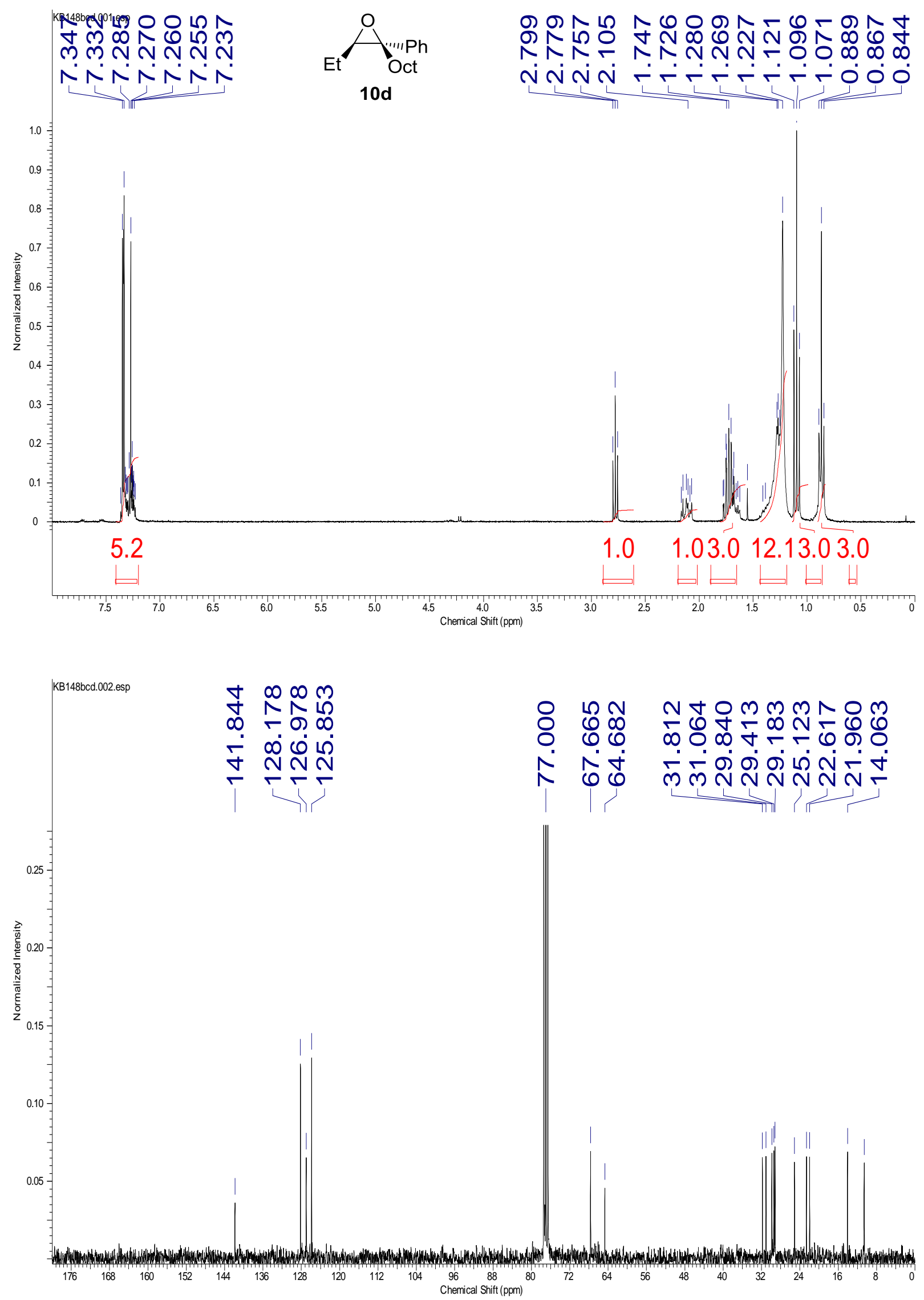

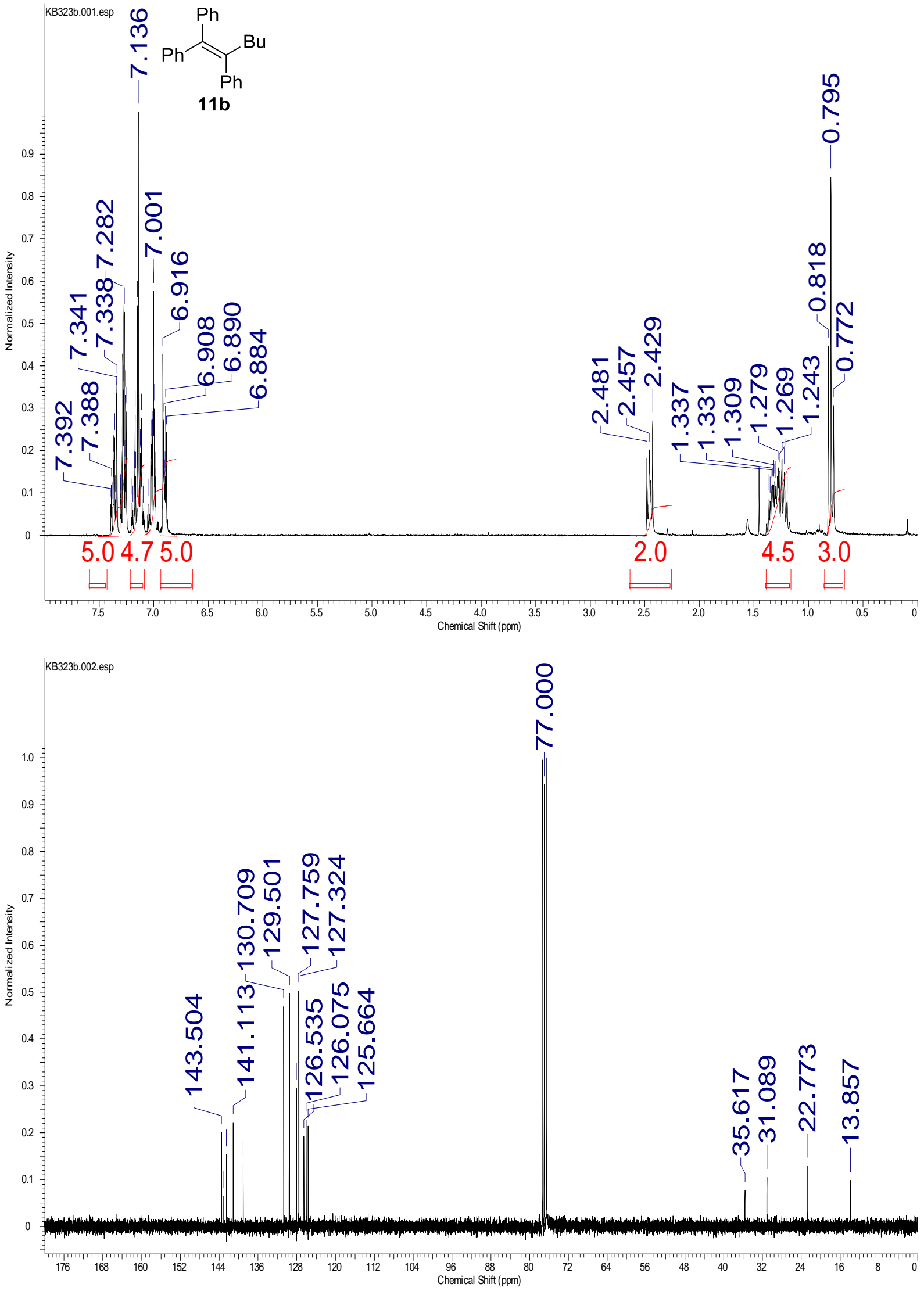

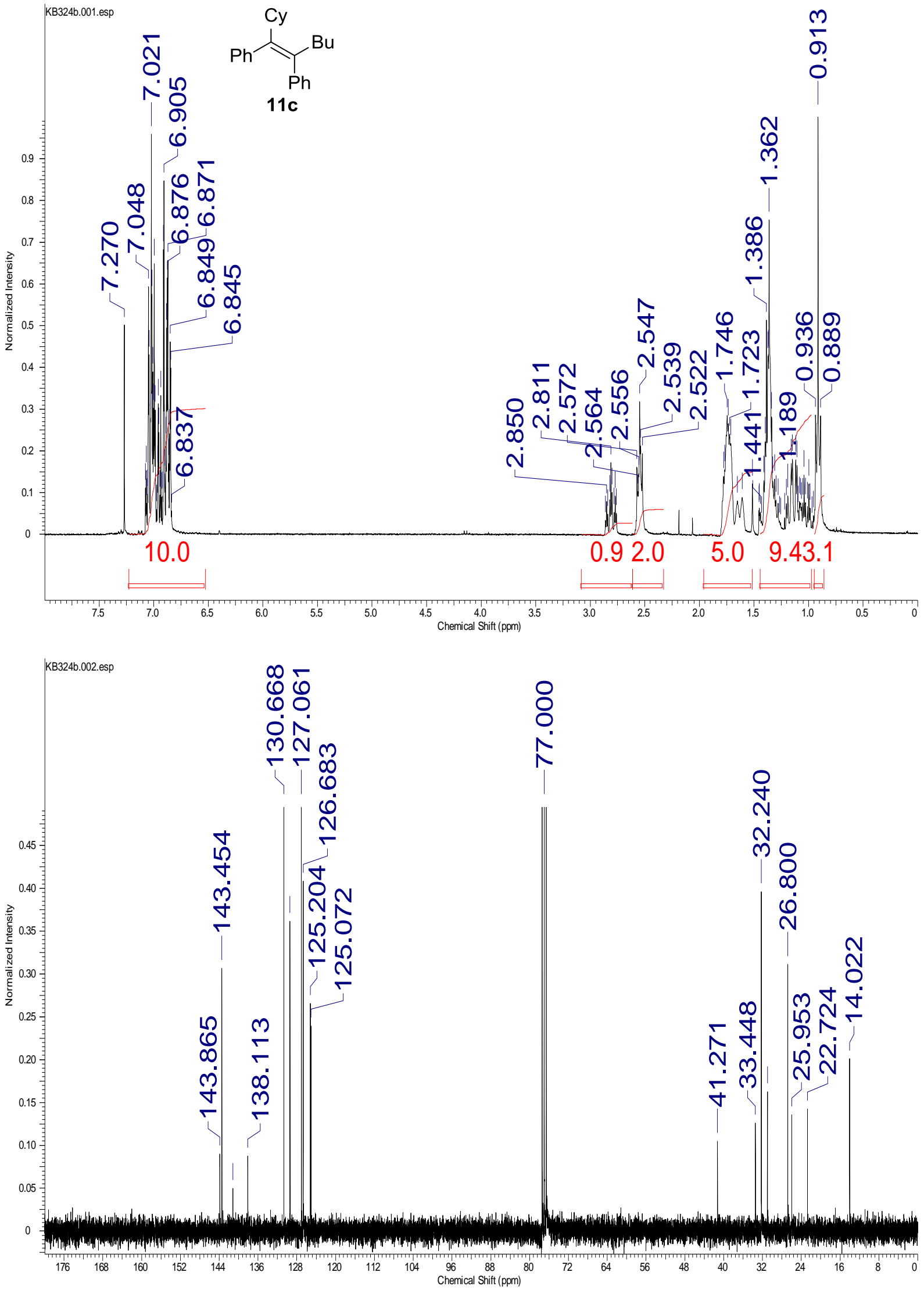

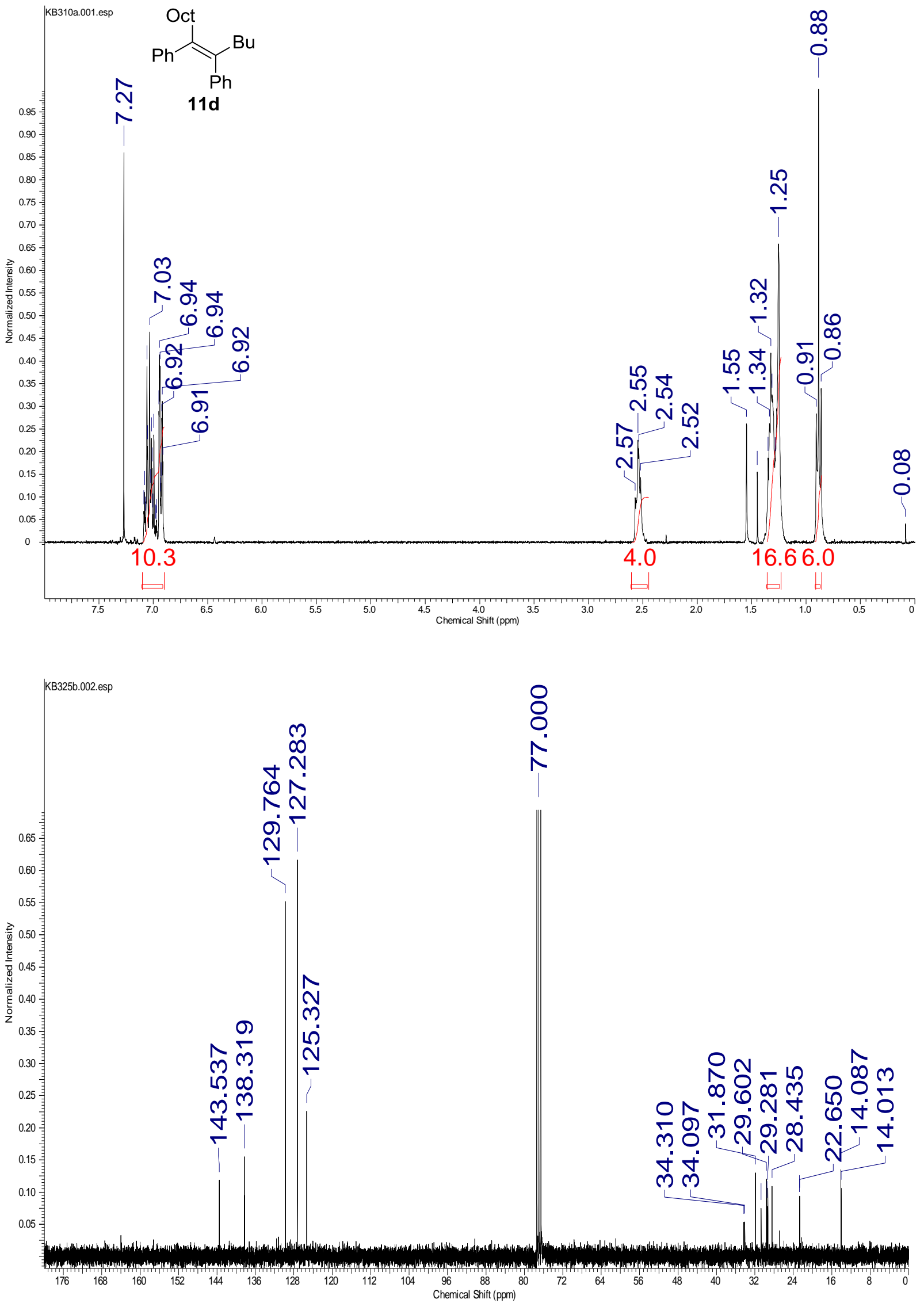

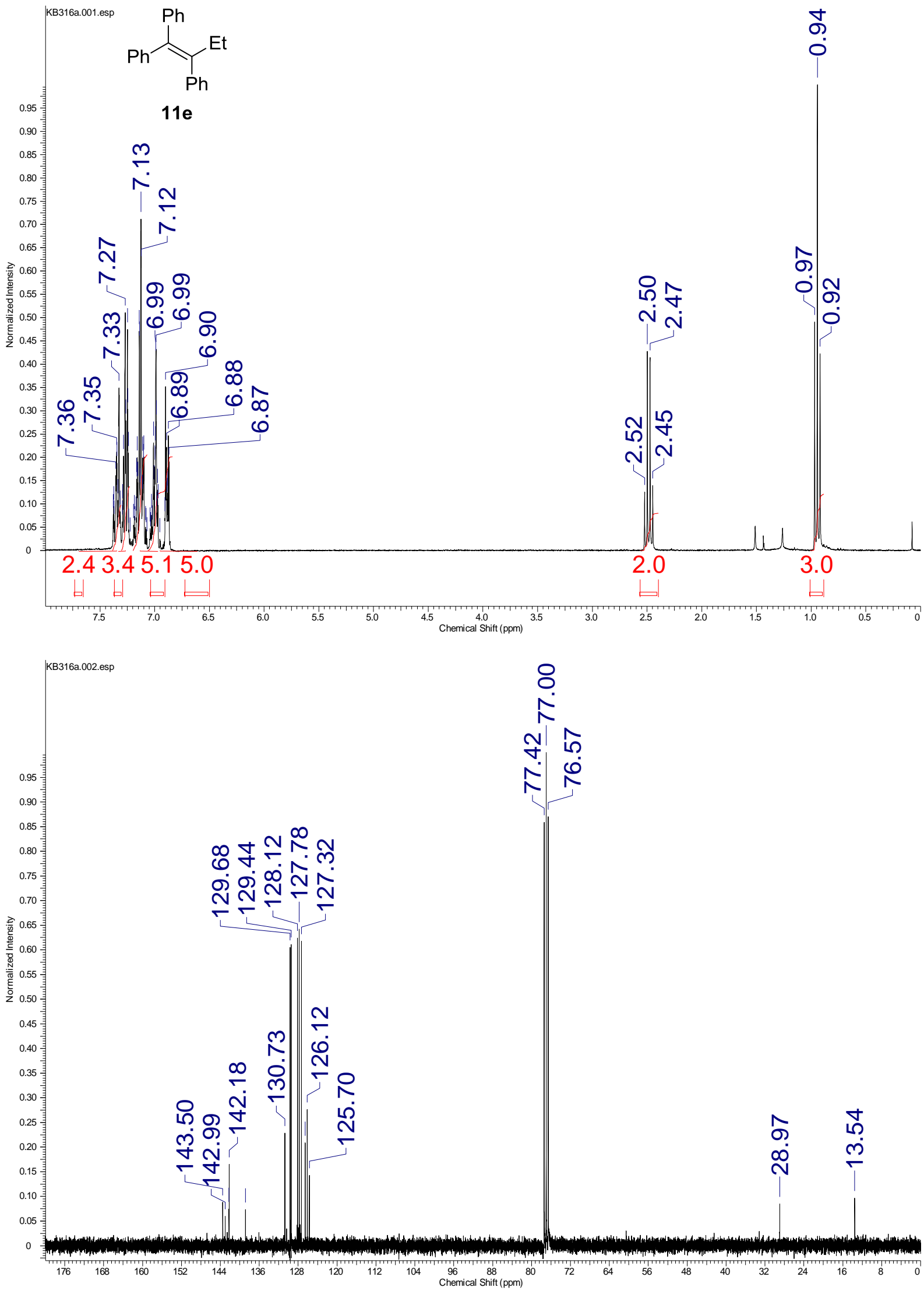

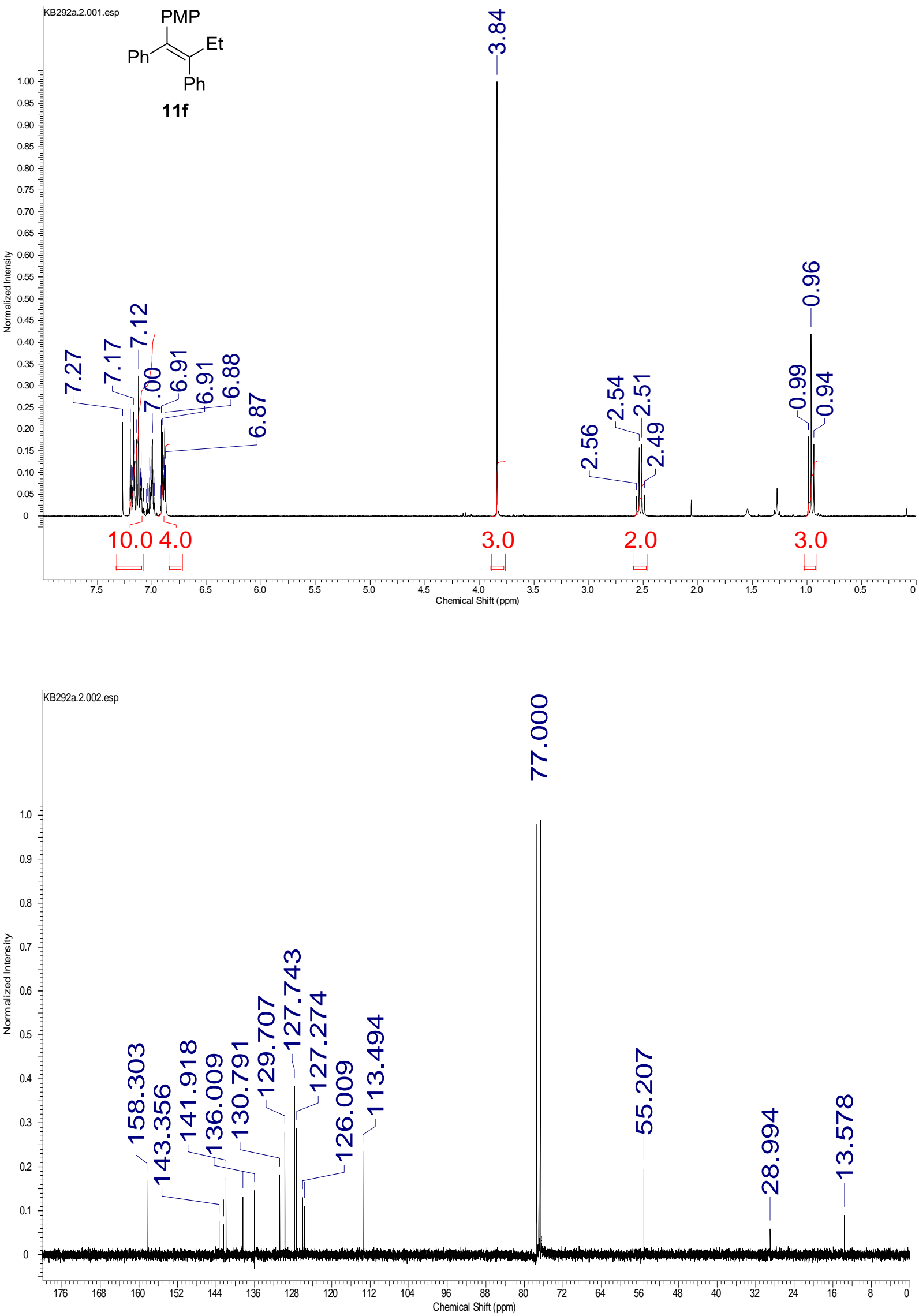

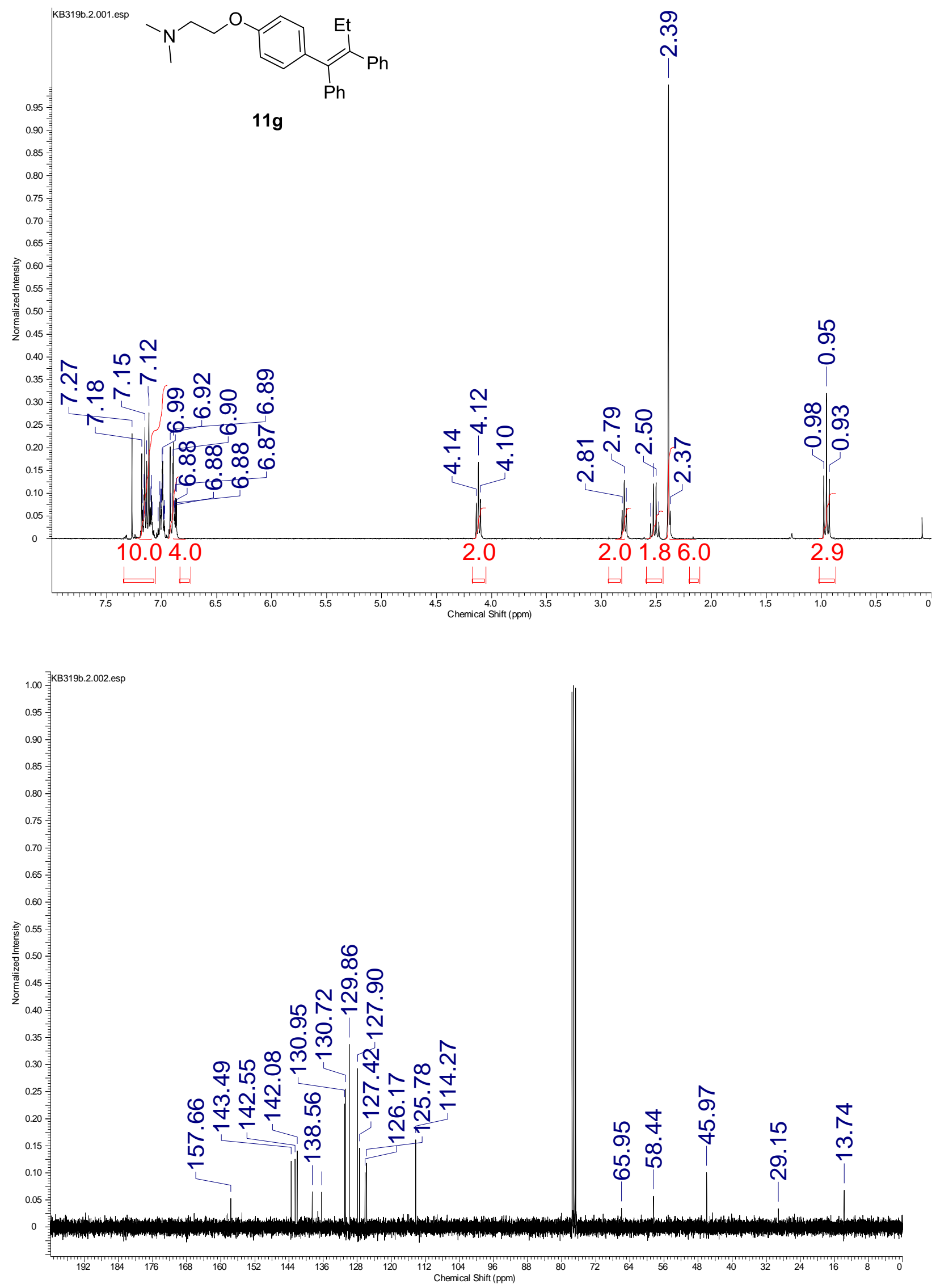